\title{
STATEMENT ON THE USE OF CONJUGATE PNEUMOCOCCAL VACCINE - 13 VALENT IN ADULTS (PNEU-C-13)
}

\section{Preamble}

The National Advisory Committee on Immunization (NACl) provides the Public Health Agency of Canada (PHAC) with ongoing and timely medical, scientific and public health advice relating to immunization. PHAC acknowledges that the advice and recommendations set out in this statement are based upon the best current available scientific knowledge and is disseminating this document for information purposes. People administering the vaccine should also be aware of the contents of the relevant product monograph(s). Recommendations for use and other information set out herein may differ from that set out in the product monograph(s) of the Canadian manufacturer(s) of the vaccine(s). Manufacturer(s) have sought approval of the vaccine(s) and provided evidence as to its safety and efficacy only when it is used in accordance with the product monographs. NACl members and liaison members conduct themselves within the context of PHAC's Policy on Conflict of Interest, including yearly declaration of potential conflict of interest.

${ }^{\dagger}$ NACI Members: Dr. B. Warshawsky (Chair), Dr. I. Gemmill (Vice-Chair), Dr. N. Crowcroft, Dr. B. Henry, Dr. D. Kumar, Dr. Quach-Thanh, Dr. M. Salvadori, Dr. B. Seifert, Dr. N. Sicard, Dr. W. Vaudry, and Dr. R. Warrington.

Liaison Representatives: Dr. J. Blake (Society of Obstetricians and Gynaecologists of Canada), Dr. A. Corriveau (Council of Chief Medical Officers of Health), Dr. S. Deeks (Canada Public Health Association), Dr. A. Mawle (U.S. Centers for Disease Control and Prevention), Dr. D. Moore (Canadian Paediatric Society), Dr. A. Pham-Huy (Canadian Association for Immunization Research and Evaluation).

Ex-Officio Representatives: Dr. M. Carew (First Nations and Inuit Health Branch, Health Canada), Lt.-Col. (Dr.) P. Eagan (Canadian Forces Health Services Group, National Defence), Dr. A. Klein (Biologics and Genetic Therapies Directorate, Health Canada), Dr. B. Law (Centre for Immunization and Respiratory Infectious Diseases, Public Health Agency of Canada), Dr. B. Raymond (Centre for Immunization and Respiratory Infectious Diseases, PHAC/Canadian Immunization Committee), Dr. E. Taylor (Marketed Health Products Directorate, Health Canda) and Ms. M. St-Laurent (Centre for Immunization and Respiratory Infectious Diseases, Public Health Agency of Canada).

†This statement was prepared by Dr. C. Quach-Thanh, and Ms. H.Thomas, and approved by NACl.

NACl gratefully acknowledges the contribution of Lt.-Col. Dr. J. Anderson, Dr. J. Brophy, Dr. P. De Wals, Dr. E. Farzad, Ms. M. Helferty, Dr. J. Johnstone, Dr. J. Kellner, Dr. J. Laroche, Dr. S. McNeil, Dr. H. Morrison, Dr. A. Opavsky, Dr. S. Rechner, Ms. L. Sherrard, Dr. G. Tyrrell, Dr. P. Van Buynder and Dr. V. Senikas. 


\section{Table of Contents}

Summary Table of Information Contained in this NACI Statement . . . . . . . . . . . . 3

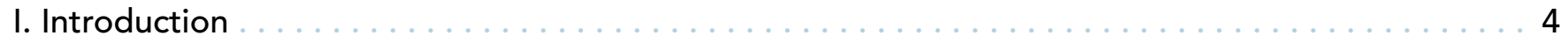

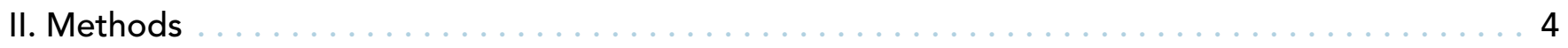

III. Epidemiology of pneumococcal disease in Canada . . . . . . . . . . . . . . . . 4

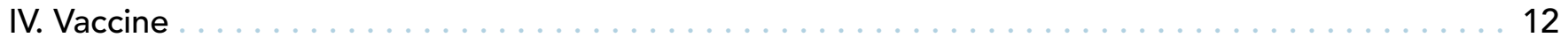

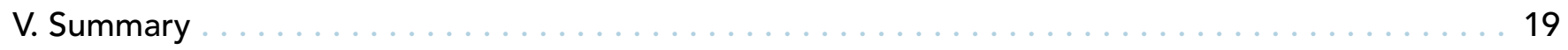

VI. Recommendations . . . . . . . . . . . . . . . . . . . . . . . . . . . . . . 19

VII. Surveillance and Research Priorities . . . . . . . . . . . . . . 21

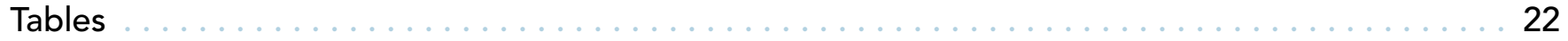

List of Abbreviations . . . . . . . . . . . . . . . . . . . . 49

References. . . . . . . . . . . . . . . . . . . . . . 50 


\section{Summary Table of Information Contained in this $\mathrm{NACl}$ Statement}

\section{The following table highlights key information for immunization providers. Please refer to the remainder of the statement for details.}

1. What

\section{What is Pneumococcal Disease?}

Streptococcus pneumoniae is a Gram-positive bacterium that is known to cause invasive disease such as sepsis, meningitis and pneumonia. Symptoms depend on the site of infection. It is a major cause of morbidity and mortality in children, the elderly population, and individuals with immunosuppression and other chronic conditions. Additional information can be found on the Public Health Agency of Canada website (www.phac-aspc.gc.ca/im/vpd-mev/pneumococcal-eng.php)

\section{What are pneumococcal vaccines?}

Two forms of pneumococcal vaccine are available; conjugated vaccines (PNEU-C-13 and PNEU-C-10) and polysaccharide vaccines (PNEU-P-23)

\section{Who}

\section{Who should be immunized?}

This statement relates to adults (18 years and older).

More specifically:

1. Adults with hematopoietic stem cell transplants (HSCT)

2. Adults with HIV

3. Adults with immunosuppressive conditions

Recommendations for children are available on the NACl website (www.phac-aspc.gc.ca/publicat/ccdr-rmtc/10vol36/acs-12/index-eng.php)

\section{How}

Dose and Schedule

For PNEU-C-13 vaccine, the dose is $0.5 \mathrm{~mL}$ administered IM.

More specifically:

1. Adults with HSCT: 3 doses of PNEU-C-13 starting 3-9 months after transplant. These doses should be administered at least 4 weeks apart, followed by a booster dose of PNEU-P-23 12 to 18 months post transplant (6 to 12 months after the last dose of PNEU-C-13).

2. Adults with HIV: 1 dose of PNEU-C-13 followed 8 weeks later by one dose of PNEU-P-23. There is currently no evidence that a PNEU-C-13 booster dose adds any benefit. The PNEU-C-13 dose should be administered at least one year after any previous dose of PNEU-P-23.

3. Adults with immunosuppressive conditions: 1 dose of PNEU-C-13 followed 8 weeks later by one dose of PNEU-P-23. There is currently no evidence that a PNEU-C-13 booster dose adds any benefit. The PNEU-C-13 dose should be administered at least one year after any previous dose of PNEU-P-23.

Precautions/Contraindications

PNEU-C-13 is contraindicated in any individual with a history of anaphylaxis to any component of the vaccine including diphtheria toxoid.

\section{Co-administration}

PNEU-C-13 can be co-administered (using a different site) with other vaccines.

\section{Why}

Current evidence supports the use of PNEU-C-13 in immunocompromised adults, as they are at a higher risk of invasive pneumococcal disease (IPD) and given the higher efficacy/effectiveness and/or immunogenicity of conjugated pneumococcal vaccine in certain immunocompromised groups.

Pneumococcal infection can cause severe infections.

The most effective way to prevent these infections is through immunization. 


\section{Introduction}

This statement will supplement previous conjugate pneumococcal statements ${ }^{1-3}$ and provide information regarding a newly authorized indication for the use of the 13-valent conjugate vaccine against pneumococcal disease, Prevnar® 13 (PNEU-C-13): As of January 2012, PNEU-C-13 has been authorized for use in adults aged 50 years and older for the prevention of invasive pneumococcal disease (IPD), including sepsis, meningitis, bacteremia, and pneumonia (with or without empyema) with bacteremia. As new data becomes available on the use of PNEU-C-13 in adults, NACl will review these data and provide new guidance as required. The 23-valent polysaccharide vaccine (PNEU-P-23) will not be discussed at length in this statement. Recommendations for its use remain unchanged. www.phac-aspc.gc.ca/publicat/ cig-gci/index-eng.php

\section{Methods}

$\mathrm{NACl}$ reviewed ${ }^{4}$ such considerations as the burden of disease and the target population, safety, immunogenicity, efficacy, effectiveness of the vaccine(s), vaccine schedules, and other aspects of the overall immunization strategy. Following critical appraisal of individual studies, summary tables with ratings of the quality of the evidence were prepared using NACl's methodological hierarchy (Tables 6 and 7), and proposed recommendations for vaccine use were developed. The Working Group chair presented the evidence and
This statement will:

- Update the epidemiology of pneumococcal disease in Canada relevant to the introduction of PNEU-C-13;

- Provide a review of the literature on the use of conjugate pneumococcal vaccines in adult populations (PNEU-C-7 and PNEU-C-13 when available); and

- Provide recommendations for the use of the 13-valent conjugate vaccine in adults (PNEU-C-13), and on the use of PNEU-P-23 related to the use of PNEU-C-13. Although PNEU-C-13 was authorized for use in adults aged 50 years and over, we will be considering adults (all age groups) with high-risk conditions for IPD and the healthy 65 years and older age group because of the burden of illness that led to the recommendation of PNEU-P-23 use in this age group.

\section{Epidemiology of pneumococcal disease in Canada}

\section{III.1 DISEASE DESCRIPTION}

Invasive pneumococcal disease (IPD) is a serious illness caused by the bacterium Streptococcus pneumoniae. There are currently 92 serotypes recognized worldwide, 15 of which cause the majority of disease. S. pneumoniae can be spread from an infected person to another person by droplets from the nose or mouth, by sneezing or coughing. Infections caused by S. pneumoniae are a major cause of morbidity and mortality worldwide. It is estimated that approximately one million children die of pneumococcal disease each year; the majority of which are young children in developing countries. In developed countries, a large burden of disease also exists among elderly persons.

Children and adults often are asymptomatically colonized with S. pneumoniae in their upper respiratory and proposed recommendations to $\mathrm{NACl}$. Following thorough review of the evidence and consultation at $\mathrm{NACl}$ meetings, the committee voted on specific recommendations. The description of relevant considerations, rationale for specific decisions, and knowledge gaps are described in the text of this statement. PHAC maintains documentation of these processes throughout knowledge synthesis and recommendation development. nasopharynx. IPD is a severe form of infection that occurs when the bacterium invades normally sterile sites, such as the bloodstream and central nervous system. The symptoms or clinical manifestations depend on the site of infection. Invasive disease may lead to several syndromes including bacteremia, meningitis, and/or pneumonia (with or without empyema) with bacteremia.

Certain conditions predispose to complications of pneumococcal infections, including sickle-cell disease, other haemoglobinopathies, chronic renal failure, chronic liver disease, immunosuppression, anatomic or functional asplenia, cerebrospinal fluid leaks, diabetes mellitus and HIV infection. Older individuals, especially those over 65 years of age, are also at increased risk for pneumococcal disease. ${ }^{5}$ 
Epidemiological data were collected from two sources of Canadian pneumococcal surveillance data: the Canadian Notifiable Disease Surveillance System (CNDSS) and the National Microbiology Laboratory (NML).

\section{III.2 DISEASE DISTRIBUTION}

Since IPD became nationally notifiable in Canada in 2000, the number of reported cases and incidence rates have increased but have been stable over the past 5 years at an incidence rate of 10 cases per 100,000 population (Figure 1). The increase in incidence rates from 2001 to 2004 was likely_at least partially_secondary to a reporting bias, where an increase in IPD case reporting occurred as the passive surveillance system was better understood and known.

FIGURE 1. Reported number of cases and incidence rate of invasive pneumococcal disease, Canada, 2001-2011

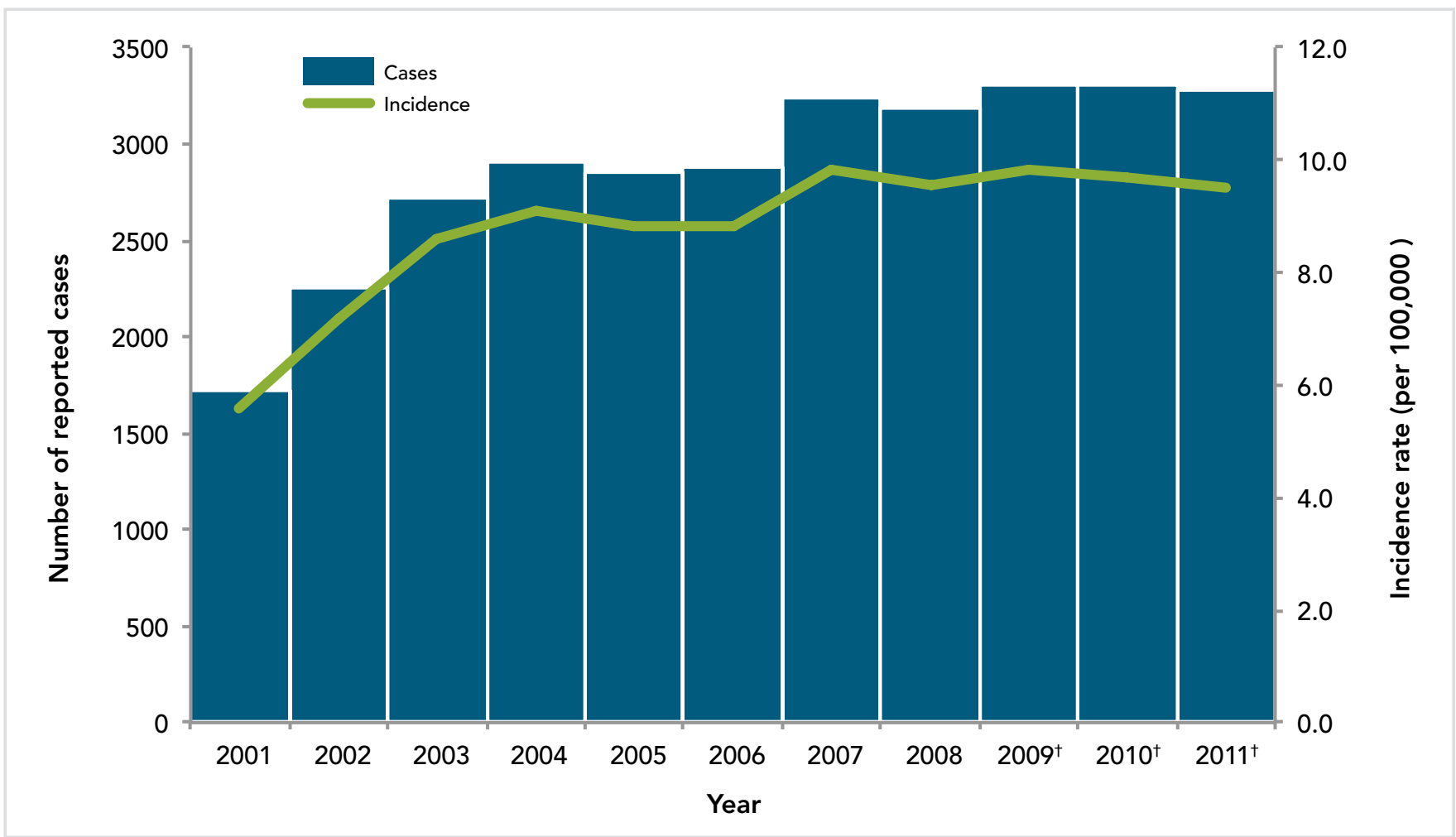

* Data obtained from the Canadian Notifiable Disease Surveillance System

† Based on preliminary data

\section{III.3 GEOGRAPHICAL DISTRIBUTION}

On average, Ontario and Quebec have the highest number of reported cases, which is expected given the large provincial population. However, the incidence rate per 100,000 population in the territories is high with high variability from year to year, most likely due to the small population size (Figure 2, Tables 1 and 2). Of note, the high incidence rate in British Columbia (BC), Alberta (AB), Saskatchewan (SK) and Manitoba (MB) was thought to be due to large outbreaks of serotype 5 in these provinces from 2006 to 2008. There was no outbreak explaining the higher incidence rates in Quebec. 
FIGURE 2. Mean number of cases and mean incidence rate of invasive pneumococcal disease (per 100,000 population), by province and territory, Canada, 2007-2011

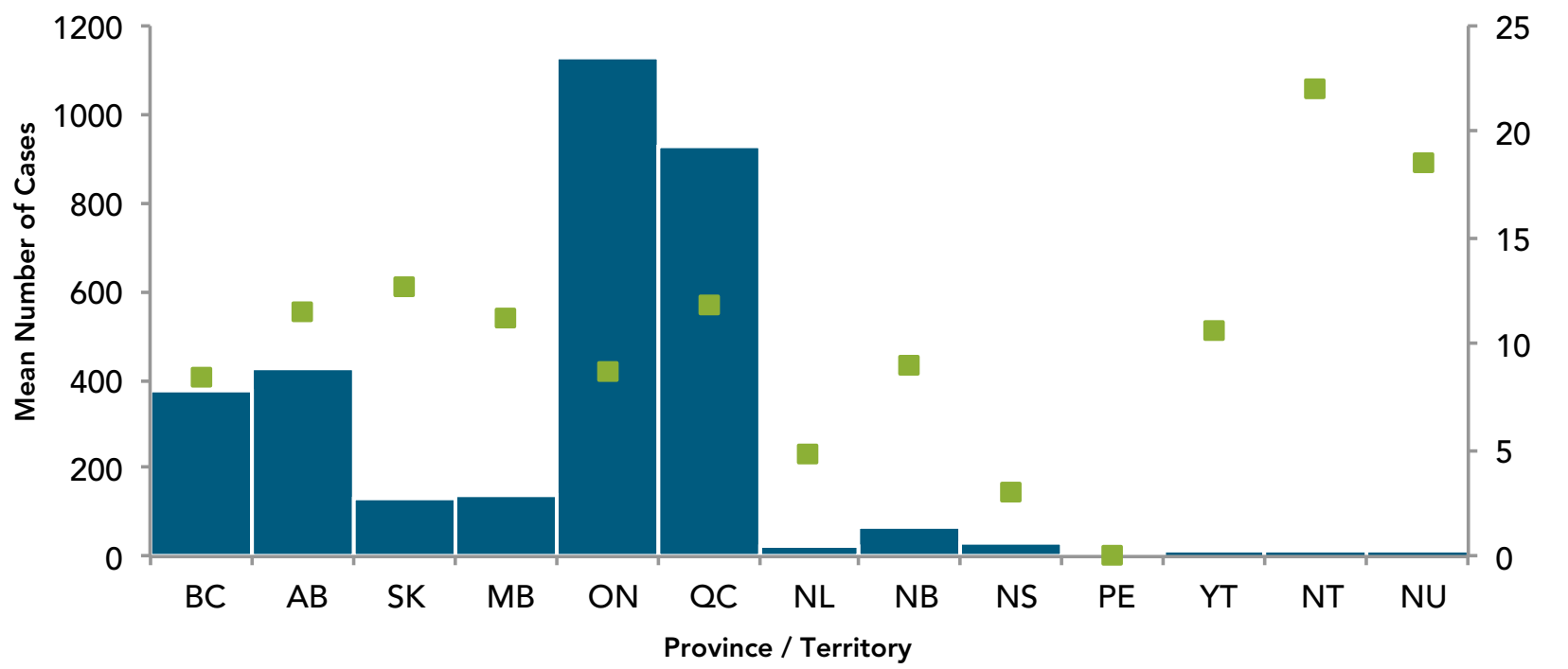

TABLE 1. Number of reported cases of invasive pneumococcal disease, by province/territory and year, Canada, 2007-2011

\begin{tabular}{|c|c|c|c|c|c|c|c|c|c|c|c|c|c|c|}
\hline \multirow[b]{2}{*}{ Year } & \multicolumn{13}{|c|}{ Province / Territory } & \multirow[b]{2}{*}{ Canada } \\
\hline & BC & $A B$ & SK & MB & ON & $\mathrm{QC}$ & NL & NB & NS & PE & YT & NT & NU & \\
\hline $\begin{array}{l}\text { Mean } \\
\text { 2001-2006 }\end{array}$ & 322 & 401 & 76 & 93 & 760 & 833 & 24 & 21 & 14 & 0 & 4 & 5 & 5 & 2557 \\
\hline 2007 & 552 & 601 & 148 & 101 & 941 & 786 & 13 & 47 & 26 & 0 & 2 & 9 & 9 & 3235 \\
\hline 2008 & 402 & 454 & 133 & 145 & 1065 & 877 & 35 & 46 & 14 & 0 & 1 & 7 & 7 & 3186 \\
\hline $2009^{\dagger}$ & 324 & 371 & 112 & 138 & 1224 & 989 & 36 & 75 & 20 & 0 & 7 & 11 & 4 & 3311 \\
\hline $2010^{\dagger}$ & 258 & 340 & 126 & 176 & 1185 & 1066 & 23 & 82 & 35 & 0 & 3 & 10 & 5 & 3309 \\
\hline $2011^{\dagger}$ & 327 & 358 & 134 & 128 & 1235 & 914 & 17 & 89 & 51 & 0 & 5 & 11 & 5 & 3274 \\
\hline $\begin{array}{l}\text { Mean } \\
\text { 2007-2011 }\end{array}$ & 373 & 425 & 131 & 138 & 1130 & 926 & 25 & 68 & 29 & 0 & 4 & 10 & 6 & 3263 \\
\hline
\end{tabular}

* Data obtained from the Canadian Notifiable Disease Surveillance System

${ }^{\dagger}$ Based on preliminary data. 
TABLE 2. Incidence rate of invasive pneumococcal disease (per 100,000 population), by year and Province/Territory, Canada, 2007 to 2011

\begin{tabular}{|c|c|c|c|c|c|c|c|c|c|c|c|c|c|c|}
\hline \multirow[b]{2}{*}{ Year } & \multicolumn{13}{|c|}{ Province / Territory } & \multirow[b]{2}{*}{ Canada } \\
\hline & BC & $A B$ & SK & MB & ON & QC & NL & NB & NS & PE & YT & NT & NU & \\
\hline $\begin{array}{l}\text { Mean } \\
2001-2006\end{array}$ & 8.05 & 12.04 & 9.95 & 9.52 & 7.33 & 11.43 & 4.71 & 5.63 & 2.22 & 0.07 & 11.81 & 15.84 & 16.84 & 8.81 \\
\hline 2007 & 12.81 & 17.11 & 14.80 & 8.46 & 7.36 & 10.22 & 2.57 & 6.30 & 2.78 & 0.00 & 6.14 & 20.67 & 28.78 & 9.82 \\
\hline 2008 & 9.17 & 12.64 & 13.12 & 12.03 & 8.23 & 11.32 & 6.91 & 6.16 & 1.49 & 0.00 & 3.02 & 16.03 & 22.13 & 9.56 \\
\hline $2009^{\dagger}$ & 7.26 & 10.10 & 10.88 & 11.32 & 9.36 & 12.64 & 7.07 & 10.00 & 2.13 & 0.00 & 20.78 & 25.21 & 12.41 & 9.82 \\
\hline $2010^{+}$ & 5.70 & 9.14 & 12.07 & 14.26 & 8.96 & 13.48 & 4.50 & 10.89 & 3.70 & 0.00 & 8.68 & 22.82 & 15.23 & 9.70 \\
\hline $2011^{\dagger}$ & 7.15 & 9.47 & 12.67 & 10.24 & 9.24 & 11.45 & 3.33 & 11.78 & 5.39 & 0.00 & 14.42 & 25.19 & 15.01 & 9.49 \\
\hline $\begin{array}{l}\text { Mean } \\
\text { 2007-2011 }\end{array}$ & 8.37 & 11.62 & 12.69 & 11.27 & 8.64 & 11.83 & 4.88 & 9.04 & 3.10 & 0.00 & 10.68 & 21.98 & 18.60 & 9.68 \\
\hline
\end{tabular}

* Data obtained from the Canadian Notifiable Disease Surveillance System.

${ }^{\dagger}$ Based on preliminary data

The PNEU-C-7 vaccine was introduced in all provincial and territorial pediatric vaccination programs by 2006 and PNEU-C-13 by 2011. Figure 3 shows the mean incidence of invasive pneumococcal disease by province and territory (P/T), both pre and post implementation of the PNEU-C-7 vaccine.

FIGURE 3. Mean annual incidence of invasive pneumococcal disease by province and territory - all age groups (per 100,000 population), pre and post PNEU-C-7 implementation, Canada, 2001-2011

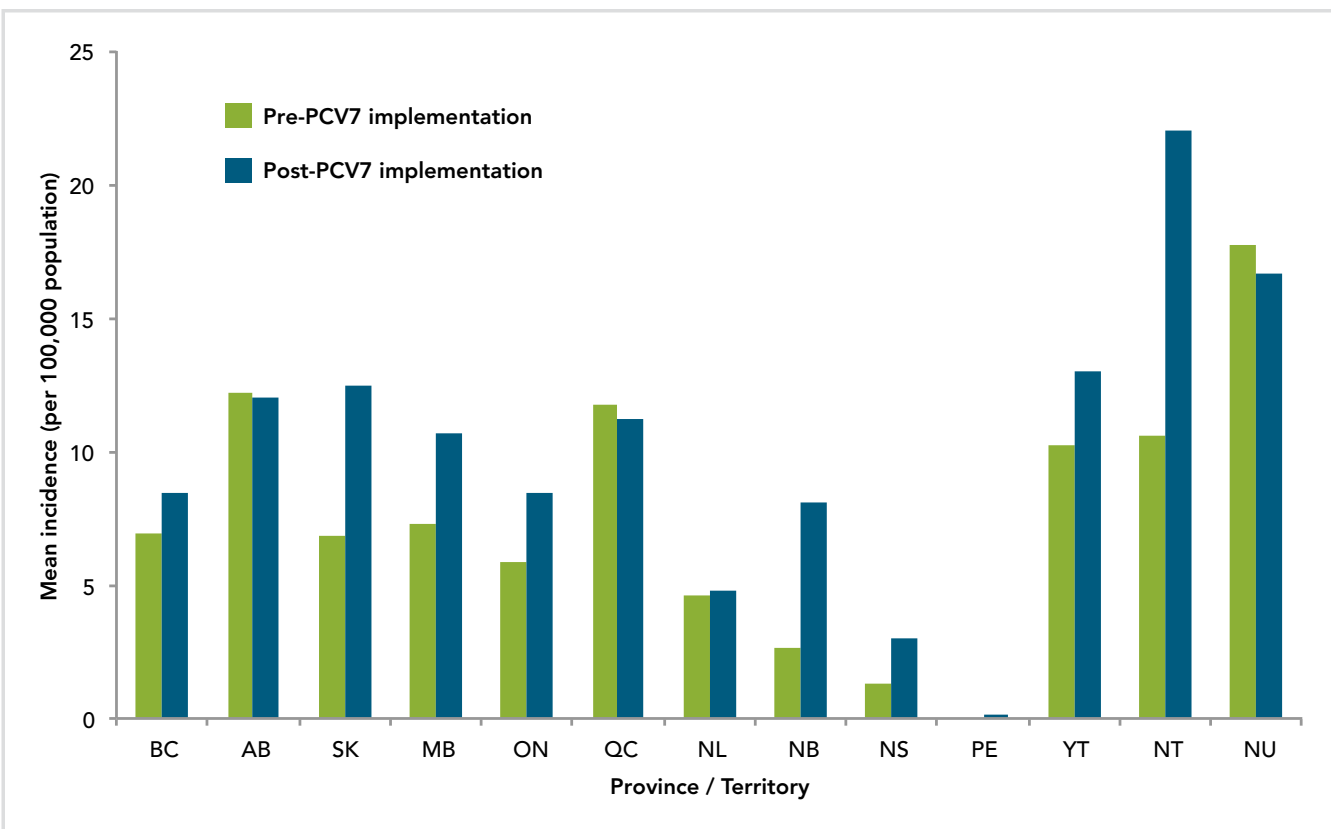

\begin{tabular}{|c|c|}
\hline P/T & $\begin{array}{c}\text { Year PCV7 } \\
\text { Implemented }\end{array}$ \\
\hline BC & 2003 \\
\hline AB & 2002 \\
\hline SK & 2005 \\
\hline MB & 2004 \\
\hline ON & 2005 \\
\hline OC & 2004 \\
\hline NL & 2005 \\
\hline NB & 2005 \\
\hline NS & 2005 \\
\hline PE & 2005 \\
\hline YT & 2005 \\
\hline NT & 2006 \\
\hline NU & 2002 \\
\hline
\end{tabular}

*Data obtained from the Canadian Notifiable Disease Surveillance System (Preliminary data from 2009-2011)

**The year in which the program was initiated is included in pre-implementation. Data were available from 2001 to 2011 for all Provinces /Territories. 


\section{III.4 AGE DISTRIBUTION}

Data on IPD by age group shows that up until 2005, children $<$ age of 5 were most affected (Figure 4). The PNEU-C-7 vaccine was introduced in all provincial and territorial vaccination programs by 2006 , and national data suggests that the introduction of PNEU-C-7 led to a decreased incidence rate among $<5$ year olds. Although, an increase in IPD incidence rate was observed from 2006 to 2008, the incidence rate was still below rates observed before vaccine introduction. A steady increase in the incidence rate among adults aged 60 years and older has occurred since 2006

FIGURE 4. Incidence rate of invasive pneumococcal disease in < 20 years old, by age group and year, Canada, 2001-2011

$\begin{array}{ll}\text { PCV7 Implementation } & \text { SK, ON, } \\ \text { NB, NS, }\end{array}$

PE, NL PNEU-C-13

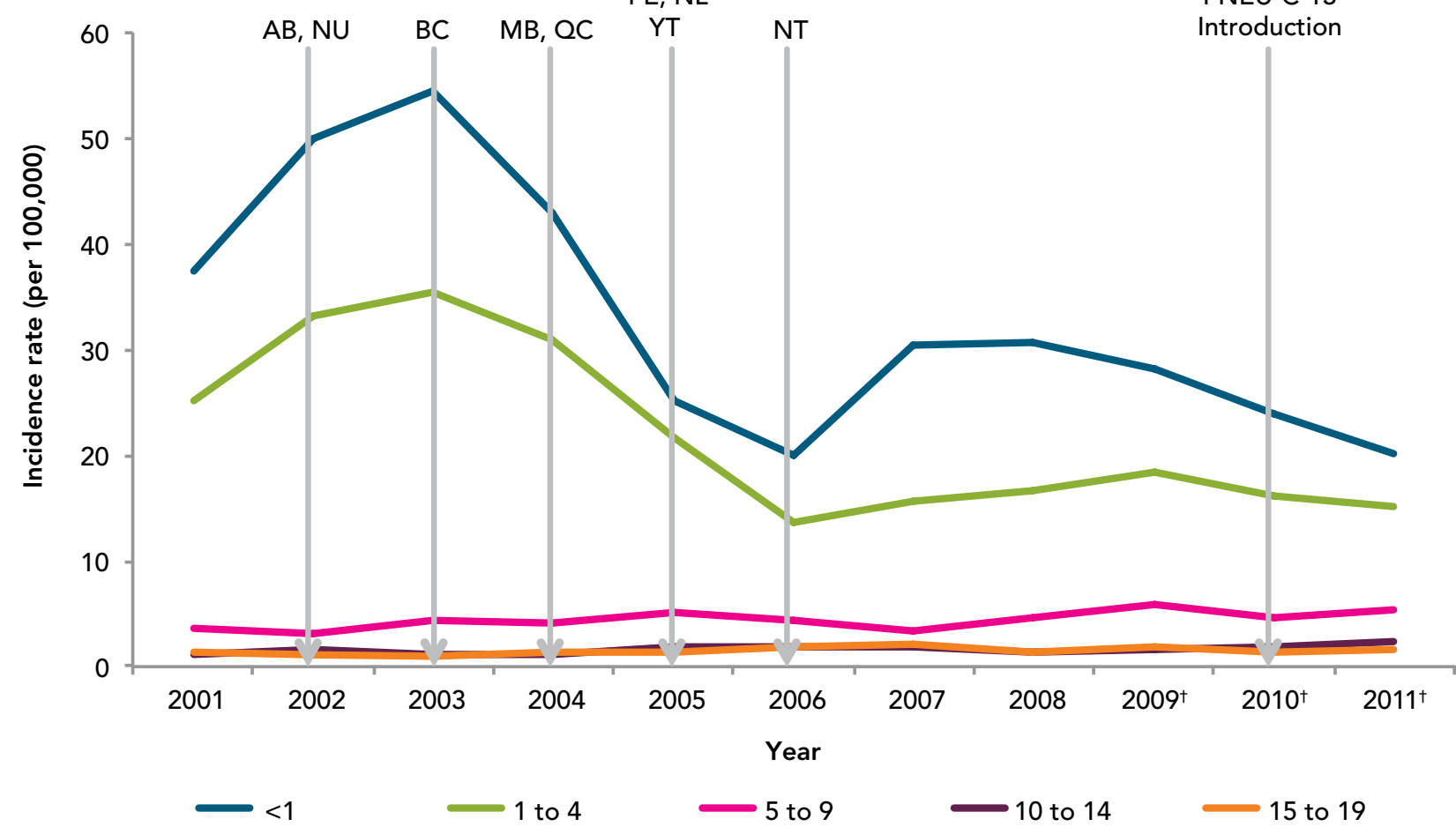

* Data obtained from the Canadian Notifiable Disease Surveillance System

† Based on preliminary data

Note: PNEU-C-10 was introduced in some Canadian provinces and territories in 2009.

Incidence rates of IPD among adults seem to increase with age, with those aged 60 years and over most affected (Figure 5). Incidence rates among older individuals has increased over time in almost all age groups, most markedly among those aged 40 to 59 and $60+$. 
FIGURE 5. Incidence rate of IPD cases aged 20 years and older, by age group and year, Canada, 2001-2011

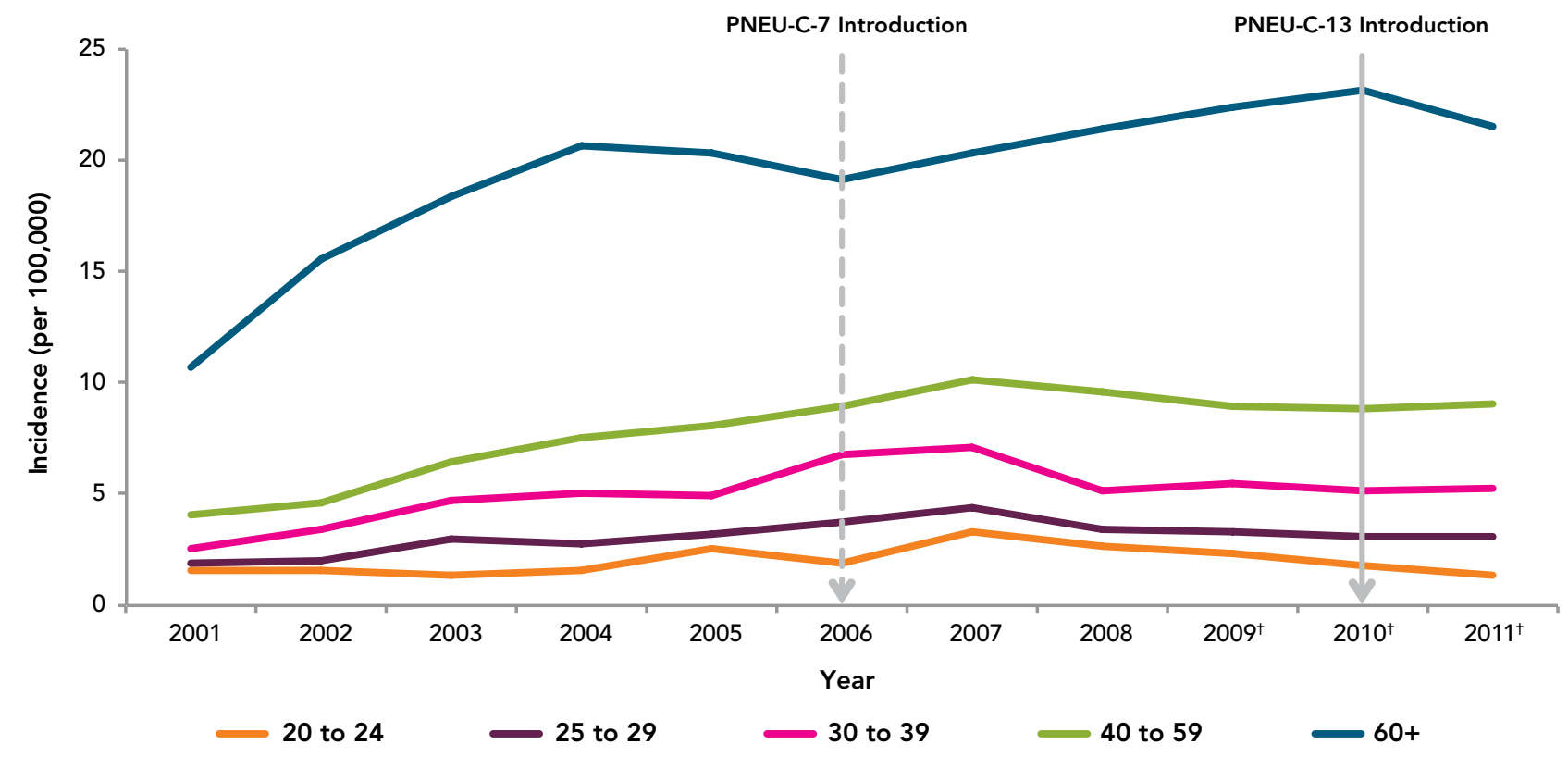

*Data obtained from the Canadian Notifiable Disease Surveillance System.

${ }^{\dagger}$ Based on preliminary data

Table 3. Number of reported cases of invasive pneumococcal disease in Canada, by age group and year, Canada, 2001-2011

\begin{tabular}{|c|c|c|c|c|c|c|c|c|c|c|}
\hline \multirow[b]{2}{*}{ Year } & \multicolumn{10}{|c|}{ Age Groups } \\
\hline & $<1$ & 1 to 4 & 5 to 9 & 10 to 14 & 15 to 19 & 20 to 24 & 25 to 29 & 30 to 39 & 40 to 59 & $60+$ \\
\hline 2001 & 124 & 359 & 72 & 24 & 30 & 33 & 39 & 124 & 358 & 558 \\
\hline 2002 & 164 & 465 & 62 & 33 & 25 & 34 & 42 & 166 & 421 & 828 \\
\hline 2003 & 180 & 490 & 85 & 25 & 21 & 30 & 63 & 223 & 602 & 1002 \\
\hline 2004 & 145 & 425 & 80 & 25 & 28 & 36 & 60 & 230 & 713 & 1161 \\
\hline 2005 & 85 & 296 & 97 & 38 & 28 & 58 & 69 & 223 & 784 & 1171 \\
\hline 2006 & 70 & 188 & 81 & 38 & 40 & 44 & 82 & 303 & 887 & 1133 \\
\hline 2007 & 110 & 221 & 62 & 40 & 48 & 75 & 99 & 319 & 1008 & 1252 \\
\hline 2008 & 114 & 237 & 81 & 29 & 30 & 61 & 79 & 234 & 957 & 1364 \\
\hline $2009^{\dagger}$ & 107 & 271 & 104 & 31 & 41 & 54 & 78 & 252 & 897 & 1475 \\
\hline $2010^{\dagger}$ & 92 & 242 & 83 & 36 & 29 & 42 & 73 & 235 & 900 & 1573 \\
\hline $2011^{\dagger}$ & 78 & 233 & 96 & 46 & 36 & 32 & 74 & 246 & 921 & 1511 \\
\hline
\end{tabular}

*Data obtained from the Canadian Notifiable Disease Surveillance System

${ }^{\dagger}$ Based on preliminary data 
Table 4. Incidence rate (per 100,000) of invasive pneumococcal disease by age group and year, Canada, 2001-2011

\begin{tabular}{|c|c|c|c|c|c|c|c|c|c|c|}
\hline \multirow[b]{2}{*}{ Year } & \multicolumn{10}{|c|}{ Age Group } \\
\hline & $<1$ & 1 to 4 & 5 to 9 & 10 to 14 & 15 to 19 & 20 to 24 & 25 to 29 & 30 to 39 & 40 to 59 & $60+$ \\
\hline 2001 & 37.37 & 25.17 & 3.57 & 1.15 & 1.42 & 1.57 & 1.88 & 2.54 & 4.08 & 10.71 \\
\hline 2002 & 50.00 & 33.24 & 3.12 & 1.56 & 1.18 & 1.59 & 2.02 & 3.45 & 4.66 & 15.53 \\
\hline 2003 & 54.51 & 35.55 & 4.36 & 1.17 & 0.99 & 1.38 & 3.00 & 4.74 & 6.49 & 18.33 \\
\hline 2004 & 42.90 & 31.04 & 4.20 & 1.17 & 1.31 & 1.63 & 2.83 & 5.00 & 7.50 & 20.70 \\
\hline 2005 & 25.06 & 21.60 & 5.20 & 1.79 & 1.29 & 2.60 & 3.21 & 4.92 & 8.08 & 20.36 \\
\hline 2006 & 19.99 & 13.58 & 4.44 & 1.81 & 1.81 & 1.95 & 3.75 & 6.74 & 9.00 & 19.11 \\
\hline 2007 & 30.54 & 15.75 & 3.44 & 1.95 & 2.14 & 3.30 & 4.44 & 7.09 & 10.16 & 20.37 \\
\hline 2008 & 30.56 & 16.56 & 4.52 & 1.44 & 1.33 & 2.67 & 3.45 & 5.17 & 9.58 & 21.43 \\
\hline $2009^{+}$ & 28.16 & 18.51 & 5.78 & 1.57 & 1.82 & 2.33 & 3.32 & 5.53 & 8.92 & 22.43 \\
\hline $2010^{\dagger}$ & 24.03 & 16.10 & 4.60 & 1.86 & 1.30 & 1.78 & 3.05 & 5.11 & 8.89 & 23.15 \\
\hline $2011^{\dagger}$ & 20.26 & 15.17 & 5.26 & 2.42 & 1.64 & 1.33 & 3.06 & 5.30 & 9.06 & 21.55 \\
\hline
\end{tabular}

*Data obtained from the Canadian Notifiable Disease Surveillance System.

${ }^{\dagger}$ Based on preliminary data

Data on underlying medical conditions unavailable

\section{III.5 SEROTYPE DISTRIBUTION OF IPD IN CANADA}

PNEU-C-7 contained the following serotypes: 4, 6B, 9V, 14, 18C, 19F, and 23F. PNEU-C-13 contains these additional serotypes: 1, 3, 5, 6A, 7F, and 19A; whereas PNEU-P-23 contains these additional serotypes: 2, 8, 9N, 10A, 11A, 12F, $15 \mathrm{~B}, 17 \mathrm{~F}, 20,22 \mathrm{~F}$, and 33F, but does not include serotype $6 \mathrm{~A}$.

National laboratory surveillance of IPD serotypes in Canada is currently accomplished through a voluntary, passive system where isolates are submitted to the National Microbiology Laboratory (NML) for diagnostic reference services. This passive surveillance system is limited by reporting differences between jurisdictions; variability in sample sizes amongst the smaller jurisdictions that result in small counts representing large relative proportions; and the availability of bacterial isolates submitted for testing.

Based on isolates submitted by the provinces and territories to the NML, as well as supplemental serotyping information provided to NML by the Laboratoire de santé publique du Québec (LSPQ) and the Toronto Invasive Bacterial Disease
Network (TIBDN), the most predominant serotypes in Canada in 2011 were 19A, 7F, 3 (all three contained in PNEU-C-13 and PNEU-P-23 but not in PNEU-C-7), 22F (contained in PNEU-P-23) and 6C (not a vaccine serotype), together accounting for $51 \%(n=1252)$ of IPD isolates tested in Canada (Figure 6). Serotype 19A, continues to be the most predominant serotype in 2011 among isolates from the $<2$ (23\%, $n=38), 2-4(41 \%, n=59), 50-64(16 \%, n=108)$ and $\geq 65$ $(14 \%, n=126)$ year olds, whereas 7F continues to be predominant in the 5-14 $(28 \%, n=39)$ and $15-49(21 \%, n=134)$ year old age groups. Serotype 3 is relatively prevalent in the $2-4 ; 50-64$ and $\geq 65$ year olds, representing 11\% ( $n=16), 8 \%$ $(n=57)$ and $11 \%(n=99)$ of the age group isolates respectively. Serotype 22F tends to be relatively prevalent in the older age groups 15-49 (7\%, $n=46), 50-64(6 \%, n=43)$ and $\geq 65(10 \%, n=90)$ year olds; whereas serotype $6 \mathrm{C}$ is prevalent in the $\geq 65$ year olds representing $7 \%(n=60)$ of the isolates tested. The proportion of PNEU-C-13 serotypes has decreased from 2010 to 2011 in the $<2$ year-old age group accounting for $63 \%(n=118)$ in 2010 to $43 \%(n=70)$ in 2011. PNEU-P-23 serotypes have remained relatively constant in all age groups over the two years (Figures 7 to 9). .-8 $^{6}$ 
Figure 6. Regional distribution of S. pneumoniae serotypes in Canada, 2011

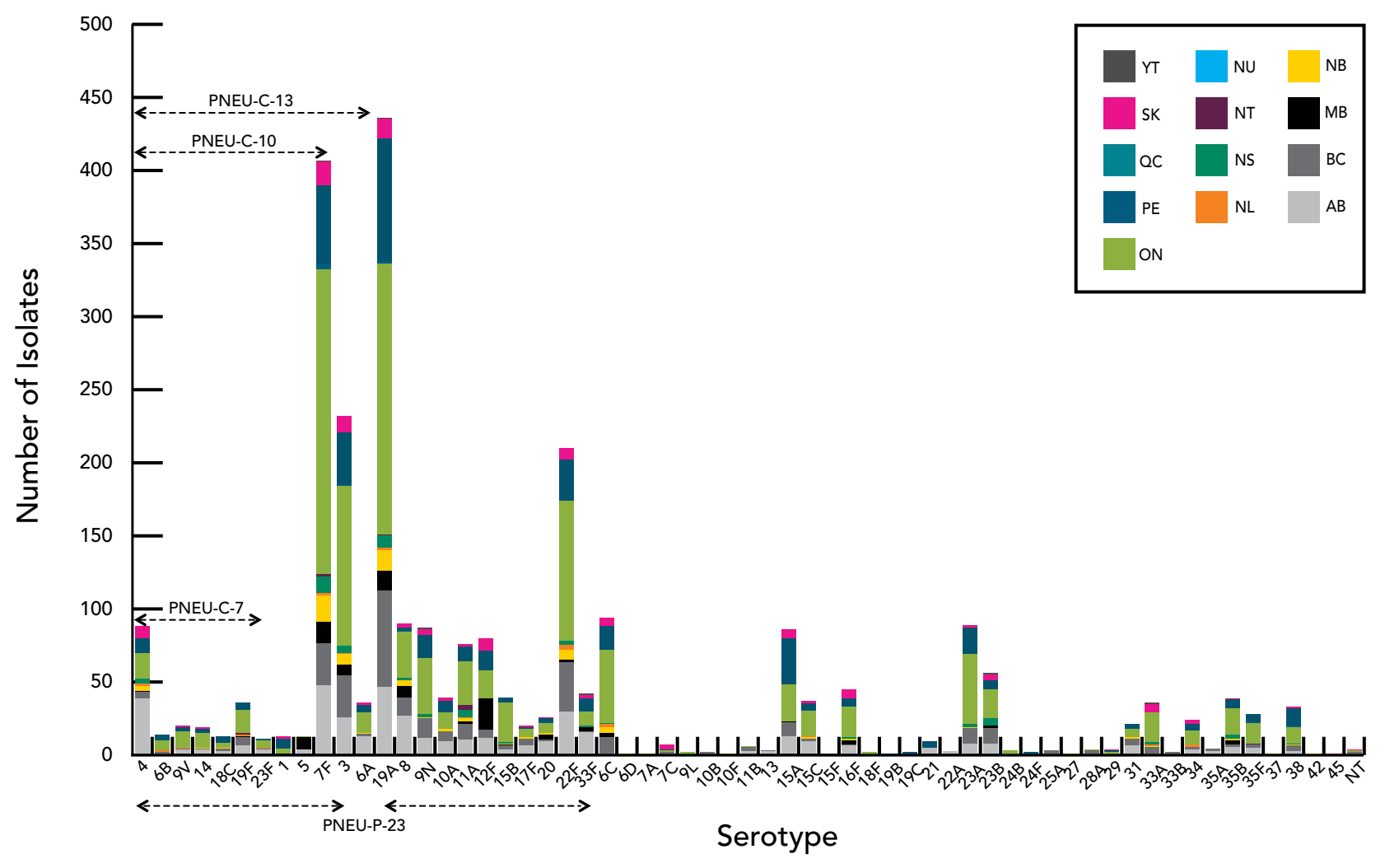

Figure 7. Proportion of PNEU-C-7 serotypes by age group, 2010-2011

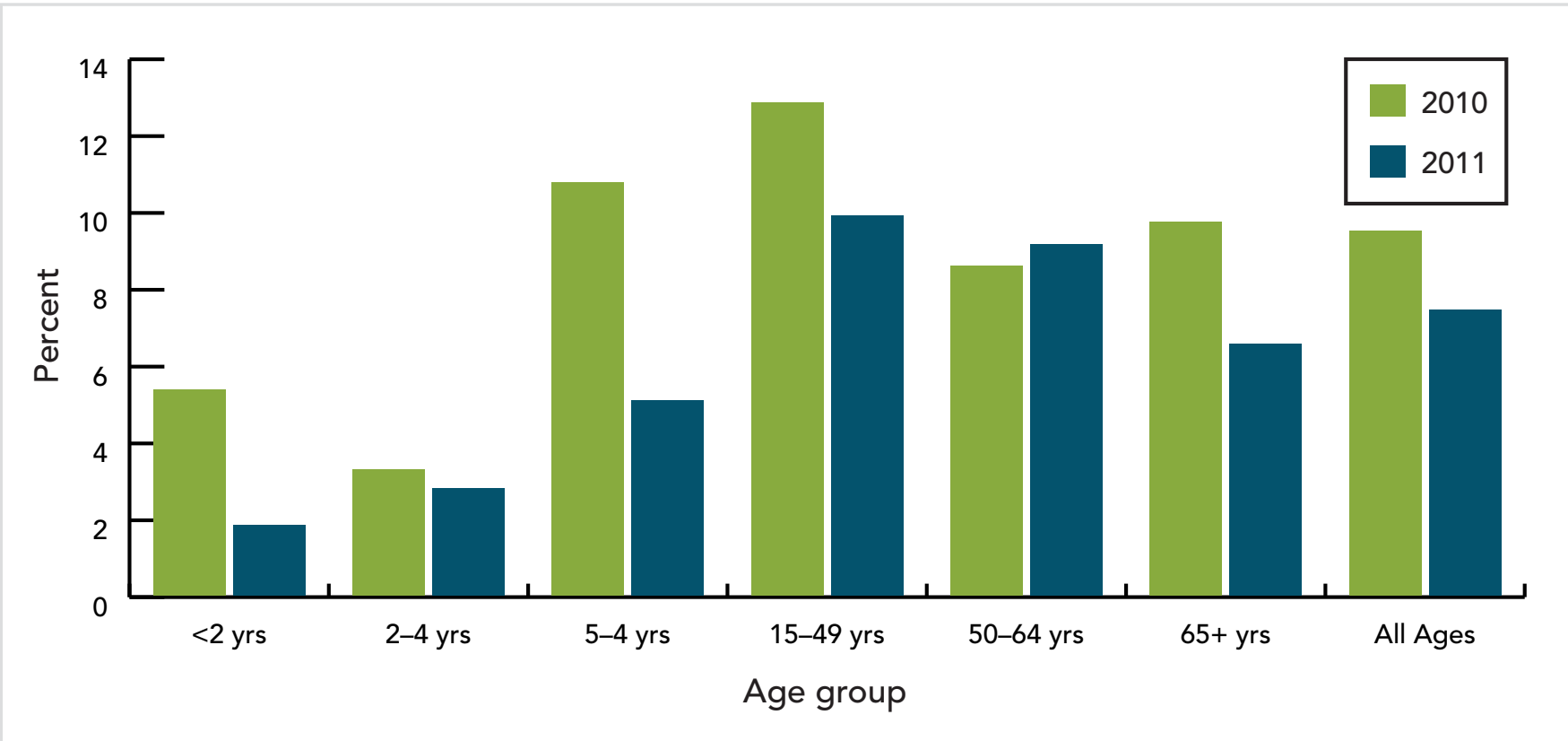


Figure 8. Proportion of PNEU-C-13 serotypes by age group, 2010-2011

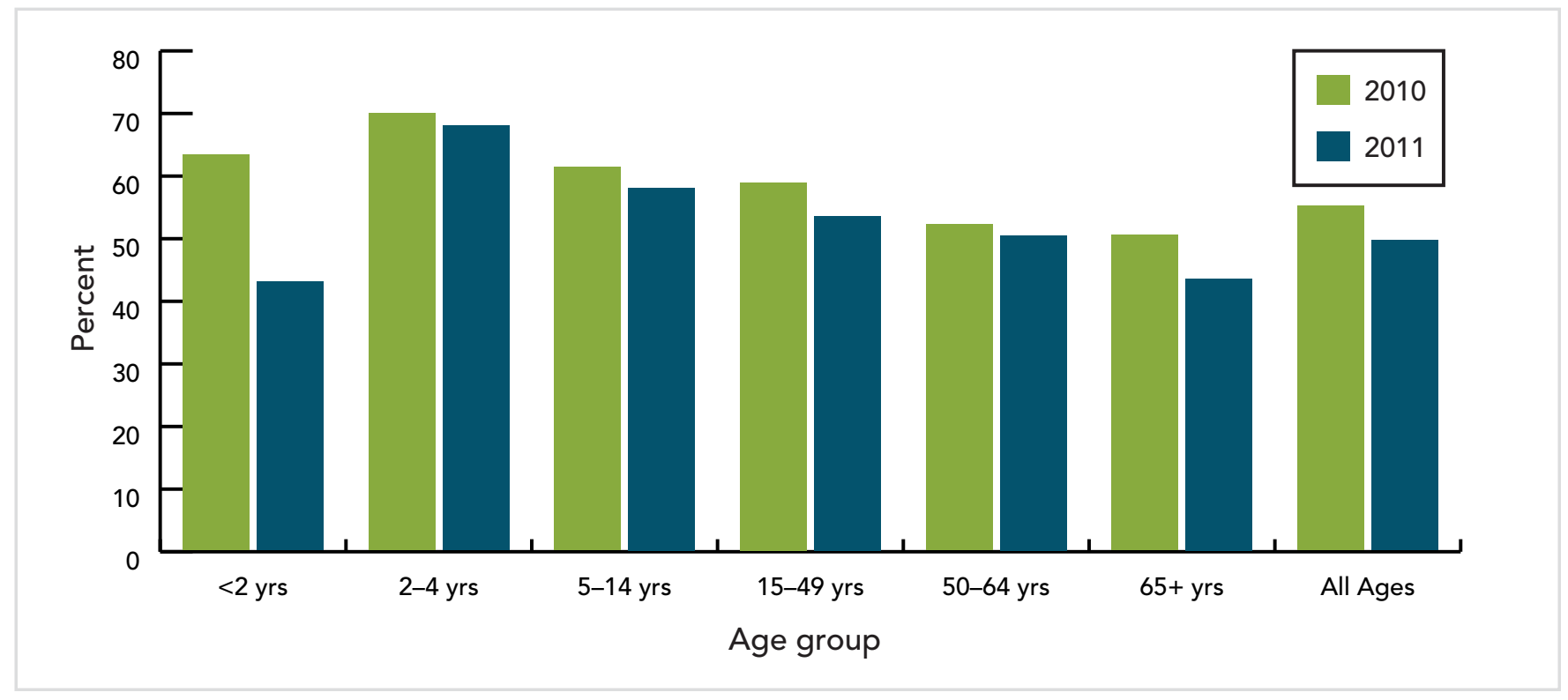

Figure 9. Proportion of PNEU-P-23 serotypes by age group, 2010-2011

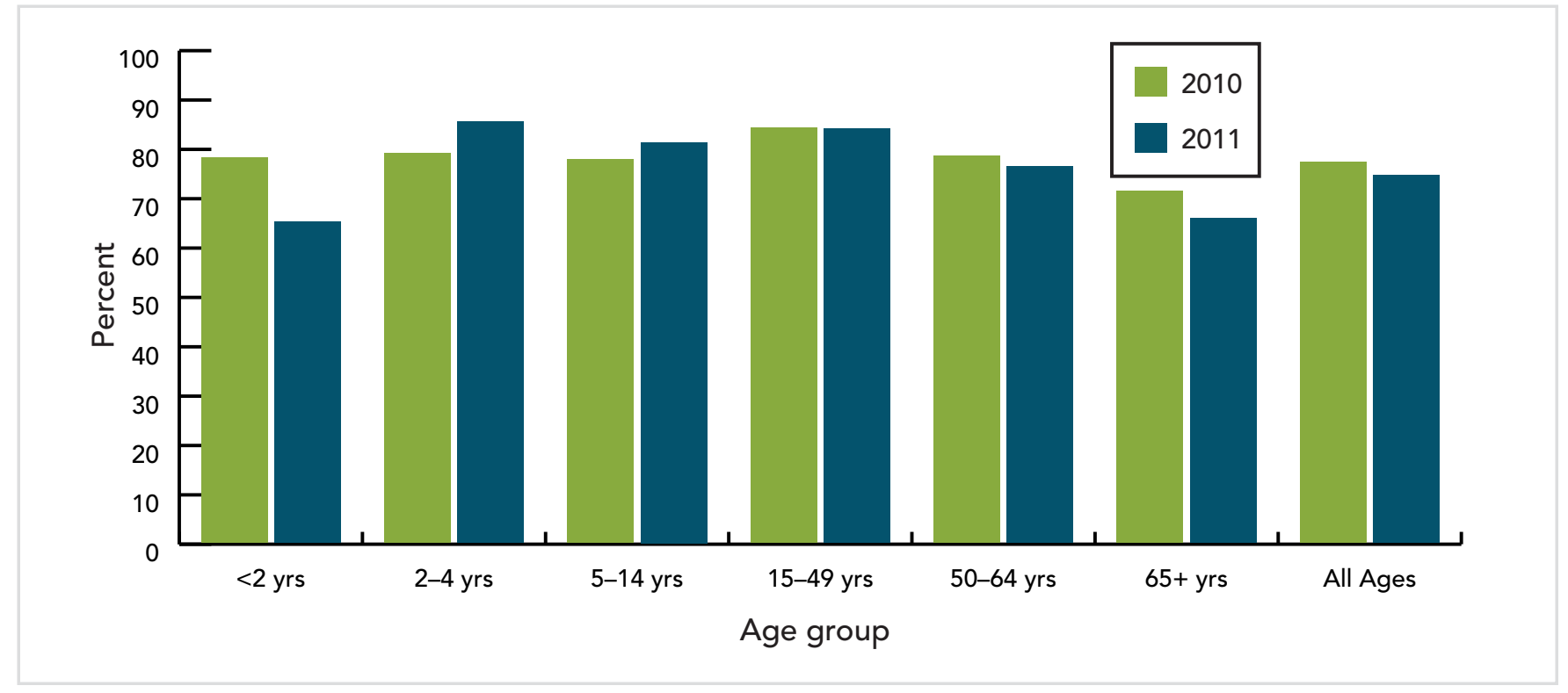

\section{Vaccine}

\section{IV.1 PREPARATION(S) AUTHORIZED FOR USE IN CANADA}

Two forms of pneumococcal vaccine are available in Canada; conjugated vaccines (PNEU-C-13 and PNEU-C-10) and polysaccharide vaccines (PNEU-P-23).

Prevnar13 $®$, a conjugated pneumococcal vaccine, is a sterile solution of polysaccharide capsular antigen of
13 serotypes of Streptococcus pneumoniae (1, 3, 4, 5, 6A, 6B, 7F, 9V, 14, 18C, 19A, 19F and 23F). The polysaccharides are conjugated individually to a diphtheria $\mathrm{CRM}_{197}$ protein carrier prior to compounding to a multivalent vaccine. The $\mathrm{CRM}_{197}$ protein carrier is adsorbed on aluminum phosphate as an adjuvant. Each $0.5 \mathrm{~mL}$ dose of vaccine contains $4.4 \mathrm{mcg}$ of the $6 \mathrm{~B}$ polysaccharide, and $2.2 \mathrm{mcg}$ each of the remaining polysaccharides. 
PNEU-C-13 is the same as PNEU-C-7 with the exception of the additional six serotypes, a modification of the conjugation for serotype $19 \mathrm{~F}$ to improve stability, the addition of $0.02 \%$ polysorbate (Tween) 80 (an excipient), and the addition of a succinate buffer. The syringe stopper is latex free.

PNEU-C-13 is marketed in a single dose, prefilled syringe containing $0.5 \mathrm{~mL}$ of vaccine.

\section{IV.2 EFFICACY - DIRECT AND INDIRECT (TABLE 1)}

\section{Please refer to Tables 1 for a detailed description of studies}

There are currently no efficacy data available for PNEU-C-13 for any adult indication. It is anticipated that efficacy data on PNEU-C-13 for the prevention of community-acquired pneumonia in adults aged 65 years and over will be available in the next few years. A thorough literature review did not reveal efficacy studies using PNEU-C-7 or -10 in healthy adults. One vaccine efficacy study done in HIV-seropositive adults was found and is summarized below.

PNEU-C-7 has a good vaccine efficacy in HIV-positive participants. French et al. randomized 439 HIV-positive patients from Malawi, who had recovered from a documented IPD, to receive either 2 doses of PNEU-C-7 or placebo. The endpoint was a new episode of IPD from one of the vaccine serotype and $6 \mathrm{~A}$, which was chosen because of potential cross-protection. The adjusted vaccine efficacy of 2 doses of PNEU-C-7 compared to placebo was $69 \%(95 \% \mathrm{Cl} 16-89) .{ }^{9}$

\section{IV.3 EFFECTIVENESS (TABLE 1)}

There is currently no data on the effectiveness of PNEU-C-13 use in adults. The only vaccine effectiveness (VE) studies that exist were done in HIV-seropositive adults and in the elderly with PNEU-P-23 and are summarized below.

\section{HIV-seropositive adults}

Even with appropriate healthcare and treatment, IPD continues to be a significant disease in HIV-seropositive adults. Siemieniuk et al. recently published a Canadian study describing 68 cases of IPD among 1946 HIV-positive adults in Southern Alberta between 2000 and 2010. The crude incidence rate, in this study, was 342/100,000 personyears. Overall, 429 (22\%) patients had never received a PNEU-P-23. Among those vaccinated, 34\% received at least 2 doses of PNEU-P-23. PNEU-P-23 vaccination was associated with a decrease in IPD incidence for vaccine serotypes (720 vs. 189/100,000 person-years before vaccination and after vaccination respectively; $\mathrm{p}<0.0001)$ and for all serotypes (768 vs. 244/100,000 person-years; $p<0.001$ ). Viral load at time of vaccination, adjusted for CD4 count, was an independent predictor of IPD. Compared to patients who had received PNEU-P-23 at least once every 5 years, patients who had received less often than every 5 years had an adjusted OR of 2.3 in their risk of IPD (95\% Cl 1.0-5.4), illustrating the limited duration of PNEU-P-23 effectiveness in this population, as shown in other publications. ${ }^{10}$ Although $78 \%$ of the population was vaccinated, $74 \%$ of IPD cases were caused by PNEU-P-23 serotypes, broken down as follows: $66 \%$ of serotypes isolated from people previously immunized were caused by PNEU-P-23 serotypes compared to $86 \%$ of serotypes isolated from people who had not been previously immunized.

Previous studies have shown the sub-optimal effectiveness of PNEU-P-23 in HIV patients in various contexts. Breiman et al. reported an adjusted vaccine effectiveness of PNEU-P-23 of $49 \%$ (95\% Cl 12-70), using a case-control design. In their study, race played an important role in vaccine effectiveness: the adjusted VE was $74 \%(95 \% \mathrm{Cl} 8$ - 93\%) in Whites and $8 \%$ (95\% - $112-60 \%$ ) in Blacks. ${ }^{11}$ Hung et al., in a prospective observational study of 507 HIV-positive patients (305 vaccinated and 203 not vaccinated with PNEU-P-23), reported an adjusted OR (aOR) for pneumococcal bacteremia of $0.22(95 \% \mathrm{Cl}$ $0.02-2.56)$, giving a $\mathrm{VE}$ of $78 \%(95 \% \mathrm{Cl}-156-98)$ and an $\mathrm{aOR}$ for all pneumococcal disease of $0.09(95 \% \mathrm{Cl} 0.01-0.74)$ for a VE of $91 \%(95 \% \mathrm{Cl} 26-99) .{ }^{12}$ French et al. had randomized 1392 HIV-infected adults in Uganda to receive either PNEU-P-23 $(n=697)$ or placebo and reported that the hazard ratio $(H R)$ for a first IPD episode was $1.48(95 \% \mathrm{Cl} 0.7$ - 3.3); the HR for an IPD due to vaccine-specific serotypes was $2.14(95 \% \mathrm{Cl}$ 0.86 - 5.31), for all-cause pneumonia $\mathrm{HR}=2.02(95 \% \mathrm{Cl}$ $1.19-3.45)$, and for all pneumococcal events $H R=1.46$ $(95 \% \mathrm{Cl} 0.73-2.91)$. The authors therefore concluded that PNEU-P-23 was ineffective in preventing pneumococcal disease in HIV-positive individuals. ${ }^{13}$

\section{Elderly population}

Vila-Corcoles et al. studied PNEU-P-23 VE in adults aged 65 years and older in a prospective cohort study $(n=4986$ unvaccinated and $n=6255$ vaccinated before study entry). The adjusted VE for the prevention of hospitalization for pneumonia was $19 \%(95 \% \mathrm{Cl}-30-49 \%)$. The VE for all-cause pneumonia was $15 \%(95 \% \mathrm{Cl}-31-44 \%)$, the VE for death from pneumonia was $72 \%(95 \% \mathrm{Cl} 20-91 \%)$, and VE for all-cause mortality was 33\% (95\% Cl 17 - 46\%). ${ }^{14}$ In a second study where 11,241 adults aged 65 years and over were followed after receipt of PNEU-P-23, Vila-Corcoles et al. 
showed that the adjusted VE for IPD due to vaccine-related serotypes was $39 \%(95 \% \mathrm{Cl}-176-87 \%)$. The VE for the prevention of pneumococcal pneumonia was $45 \%(95 \% \mathrm{Cl}$ $12-66 \%)$, the VE for the prevention of hospitalization for pneumonia was $26 \%(95 \% \mathrm{Cl} 8-41 \%)$, and the VE for the prevention of overall pneumonia was $21 \%(95 \% \mathrm{Cl} 2-36 \%)$. Once stratified for influenza vaccination status, the authors reported a PNEU-P-23 VE in decreasing the risk of hospitalization for pneumonia in influenza non-vaccinated individuals of $35 \%$ $(95 \% \mathrm{Cl} 1-57 \%) .{ }^{15}$

Mooney et al. also looked at PNEU-P-23 VE in adults aged 65 years and over in Scotland, using a retrospective cohort design, for the prevention of IPD. The adjusted VE (excluding high risk patients) was $61.7 \%(95 \% \mathrm{Cl} 45.1-73.2 \%)$, giving a number needed to vaccinate of 5,206 $(95 \% \mathrm{Cl} 4388-7122)$. The adjusted VE for adults aged $65-74$ years, excluding high-risk patients, was $54.4 \%(95 \% \mathrm{Cl} 20.1-74 \%)$ and it was $68.8 \%(95 \% \mathrm{Cl} 52.0-79.8 \%)$ in adults aged 75 years and older. ${ }^{16}$

Melegaro et al. published a meta-analysis of PNEU-P-23 VE. Pooled estimates of VE against pneumococcal pneumonia using random effects model, excluding high-risk groups, gave an estimate of $16 \%(95 \% \mathrm{Cl}-50-50 \%)$; when high-risk groups were included, VE was $-20 \%(95 \% \mathrm{Cl}-92-25 \%)$.

The pooled VE estimate against IPD in the general elderly population was $65 \%(95 \% \mathrm{Cl}-42-92 \%)$; VE in high-risk groups was $20 \%(95 \% \mathrm{Cl}-187-78 \%) .{ }^{17}$ This meta-analysis showed that PNEU-P-23 had a very limited VE in the elderly population.

\section{IV.4 IMMUNOGENICITY (TABLE 1)}

The following at-risk groups were reviewed separately: transplant recipients (solid organ and hematopoietic stem cells), HIV seropositive subjects, and the elderly population (aged 65 years and over).

\section{Transplant Recipients}

\section{A) Solid Organ Transplant (SOT) Recipients:}

Kumar et al. published a randomized, placebocontrolled trial (RCT) of 130 participants who had undergone a liver transplant at least 3 months before study enrolment and, if previously vaccinated with PNEU-P-23, had received this vaccine at least 5 years prior to study enrolment. Sixty-five participants were randomized to receive a placebo followed by PNEU-P-23 eight weeks later or PNEU-C-7 followed by PNEU-P-23 eight weeks later. There was no difference in the proportion of participants who had previously been vaccinated with PNEU-P-23 (8\% in placebo vs. 14\% in PNEU-C-7, $p=0.17)$, who were receiving prednisone $(p=0.09)$, or had previously received anti-thymocyte globulin therapy $(p=0.06)$. There was no difference in the proportion of liver transplant recipients who responded to at least 1 serotype at 16 weeks (85.7\% vs. $91.2 \%$ for placebo and PNEU-C-7, respectively) or in the mean number of serotypes with a response $(3.7 \pm 2.3$ vs. $4.4 \pm 2.2$ for placebo and PNEU-C-7, respectively). There was no difference in the serotype-specific geometric mean titers (GMT - antibody level) at 16 weeks after the first vaccine dose or in the opsonophagocytic activity (OPA - considered the best functional measure, as it represents the host's primary defense mechanism against pneumococcal infections18) when comparing placebo and PNEU-C-7, each followed by PNEU-P-23. ${ }^{19}$

Kumar et al. also published a double-blinded RCT of 60 participants who had undergone a renal transplant 3 months to 3 years before the study. Splenectomized patients or those who had received PNEU-P-23 in the last 5 years were excluded. The majority of participants were still receiving cyclosporine, corticosteroids, or Mycophenolate mofetil (MMF) at the time of vaccination. Thirty participants in each group were randomized to receive either PNEU-P-23 or PNEU-C-7. Baseline characteristics in both groups were similar. There was no significant difference in the serotype-specific GMT mean fold-increase at eight weeks compared to baseline for the two study groups for 5 of 7 serotypes $(4,6 B, 14,18 C$, 19F). GMT increase was higher after PNEU-C-7 compared to PNEU-P-23 for serotype 23F and had a trend towards better response for serotype 9 $(p=0.09)$. The proportion of participants who responded (ELISA titers at least 2-fold increase compared to baseline with absolute titer of at least $1 \mu \mathrm{g} / \mathrm{mL}$ ) to at least 1 serotype was not statistically significantly different in both groups $(73.3 \%$ vs. 53.3\% for PNEU-C-7 and PNEU-P-23, respectively; $\mathrm{p}=0.11)$. The median number of serotypes with a response was 2.5 (PNEU-C-7) and 1.0 (PNEU-P-23) $p=0.069$. There was no difference between groups for OPA titers-fold increase: an OPA response to any serotype was present in $80 \%$ of participants after PNEU-C-7 and in $83.3 \%$ of participants after PNEU-P-23. ${ }^{20} \mathrm{~A}$ follow-up 3 years later (PNEU-C-7 $[n=23]$ or PNEU-P-23 [ $n=24]$ ) showed that there 
was no difference in the proportion of participants who maintained a serotype-specific response at 3 years for all 7 serotypes. The overall GMT at 3 years declined significantly for 6 of 7 serotypes compared to the eight-week titers, except for serotype $19 \mathrm{~F}$ (not different). However, the 3-year titers were significantly greater than pre-vaccination titers for all serotypes except 14 in both groups. The rate of decline in GMT was similar in both groups. ${ }^{21}$

Tobudic et al. ${ }^{22}$ completed a randomized single blind controlled study to investigate the use of PNEU-C-7 or PNEU-P-23 as priming doses to a PNEU-P-23 boost one year later in adult renal transplant recipients. Transplantation had occurred at least 6 months prior to study enrollment. Exclusion criteria included splenectomy, pneumococcal vaccine within the preceding 5 years, treatment for allograft rejection, IVIG within the previous 6 weeks and an acute febrile illness within 2 weeks of study enrollment. A total of 80 participants were randomized to receive either PNEU-C-7 or PNEU-P-23 followed by a booster dose of PNEU-P-23 1 year later. Immunogenicity results were compared after the second dose of pneumococcal vaccine in both groups, but were also compared to immunogenicity results obtained after the initial dose of PNEU-P-23 received upon enrolment. Outcomes measures were a 2-fold increase in the antibody concentration from baseline and an absolute post vaccination value of $>1 \mu \mathrm{g} / \mathrm{mL}$. After the initial dose, in the PNEU-C-7 group, $77.1 \%$ of subjects had a response to at least one serotype as compared to $93.1 \%$ in the PNEU-P-23 group ( $p=0.046$ ). One year later, after a second vaccination with PNEU-P-23, the response to at least one serotype was $87.5 \%$ in the PNEU-C-7/PNEU-P-23 group and $87.1 \%$ in the PNEU-P-23/PNEU-P-23 group. The median number of serotypes with a response was not statistically different between the two groups. Based on these findings, the authors concluded that a single dose of PNEU-P-23 should continue to be the standard of care in adult renal transplant recipients.

\section{B) Hematopoietic Stem Cell Transplant (HSCT) Recipients:}

Cordonnier et al. published a multicenter RCT where 158 allogeneic HSCT recipients were randomized to receive either PNEU-C-7 at 3, 4, and 5 months post-HSCT followed by PNEU-P-23 (early group; $\mathrm{n}=75$ ) at 12 months post-HSCT or PNEU-C-7 at 9, 10 , and 11 months post-HSCT followed by PNEU-P-23 at 18 months post-HSCT (late group; $n=83$ ). Baseline characteristics were similar in both groups but differed significantly in the proportion of participants with antibody titers $\geq 0.15 \mu \mathrm{g} / \mathrm{mL}$ to all 7 serotypes prior to PNEU-C-7 vaccination (44\% in early group vs. $9 \%$ in late group; $p<0.001)$. One month after the 3rd dose of PNEU-C-7, 79 and $82 \%$ of participants had an antibody titer $\geq 0.15 \mu \mathrm{g} / \mathrm{mL}$ to all 7 serotypes and 56 vs. $54 \%$ had a response to all 7 serotypes (GMT $\geq 0.5 \mu \mathrm{g} / \mathrm{mL}$ ) in the early and late group, respectively. At 24 months post-HSCT, 59\% vs. 83\% $(p=0.013)$ of participants had an antibody titer $\geq$ $0.15 \mu \mathrm{g} / \mathrm{mL}$ to all 7 serotypes and $34 \%$ vs. $55 \%$ had a response to all 7 serotypes (GMT $\geq 0.5 \mu \mathrm{g} / \mathrm{mL}$ ) in the early and late group, respectively. One month after the 3rd dose of PNEU-C-7, GMTs were not different for any of the serotypes in both groups. However, at 24 months post-HSCT, GMTs were significantly lower for all serotypes except $23 \mathrm{~F}$ in the early vaccination group. ${ }^{23}$

Molrine et al. studied immunization of donors in a RCT of allogeneic HSCT recipients. Donors were immunized or not with PNEU-C-7 10 days prior to harvest and transplantation. All recipients received PNEU-C-7 at 3, 6, and 12 months post-HSCT. Donors for 30 HSCT recipients were immunized; donors for 35 were unimmunized, and 31 recipients were not evaluable (21 died in the peri-transplantation period, 5 were excluded prior to transplantation, 2 were excluded because of protocol violation, and 3 relapsed). There was no difference in the proportion of recipients who had a GMT $\geq 0.5 \mu \mathrm{g} / \mathrm{mL}$ at 3, 12, and 13 months post-HSCT when comparing both groups. Differences between GMTs were significantly higher at 6 and 12 months post transplant for serotypes 6B, 9V, 18C, 19F, and 23F when the donor was immunized. Although difficult to interpret, the authors compared GMT concentrations after PNEU-C-7 in their study with results from a previous study of allogeneic HSCT participants who had received PNEU-P-23 at 12 months post transplant. GMT concentrations were significantly higher for the 7 common serotypes after PNEU-C-7 than after PNEU-P-23. ${ }^{24}$

Kumar et al. randomized 64 donor-recipient allogeneic HSCT pairs (32 pairs in each group) so that each pair received either PNEU-P-23 or PNEU-C-7: donors were vaccinated at least 2 weeks prior to harvesting and HSCT recipients received 1 dose at 6 months post-HSCT. Both groups (donors 
and recipients) were similar in terms of baseline characteristics. Donors' GMTs - 2 weeks after vaccination - were not different between both groups. At 6 months post-HSCT, GMTs were similar for all 7 serotypes, except for 6B (higher after PNEU-C-7). At 12 months post-HSCT, GMTs were higher after PNEU-C-7 for serotypes 14 and $18 \mathrm{C}$. A response to at least 1 serotype $(\geq 0.35 \mu \mathrm{g} / \mathrm{mL})$ occurred in $38.1 \%$ and $0 \%$ of HSCT recipients after PNEU-C-7 and PNEU-P-23 at 6 months post-HSCT, respectively $(p=0.003)$. At 12 months post-HSCT, the proportion of respondents was $90.8 \%$ vs. $55.6 \%$ in the PNEU-C-7 vs. PNEU-P-23 groups, respectively $(p=0.02) .{ }^{25}$

\section{HIV-seropositive participants}

Feikin et al. randomized 90 HIV-positive patients (CD4 of at least 200 cells $/ \mu$ l) to receive 2 doses of a combination of placebo, PNEU-C-7, and PNEU-P-23. There were 67 evaluable participants. Participants receiving PNEU-C-7 tended to have an improved response compared to PNEU-P-23 for 3 of 5 serotypes tested (23F, 4, 9V). However, the 2 nd dose of vaccine did not add any additional benefit: after the 2 nd dose geometric mean concentrations (GMC) were equivalent for participants who had received PNEU-C-7/ PNEU-C-7 or PNEU-C-7/PNEU-P-23. OPA titers were significantly better after PNEU-C-7 compared to PNEU-P-23 for the 5 serotypes tested. Again, the 2 nd dose did not further increase OPA titers. ${ }^{26}$

Penaranda et al. randomized 220 HIV-positive patients (CD4: 200-500 cells/ $\mu$ l, viral load $<5$ log copies/mL) to receive either PNEU-C-7/PNEU-P-23 or PNEU-P-23 ( $n=110$ in each group). The baseline characteristics were similar in both groups with a high proportion of patients on highly active antiretroviral therapy (HAART) (98 and 91\%). There was no statistical difference in the proportion of responders at 8 weeks, based on lgG 2-fold increase with a minimum level of $1 \mu \mathrm{g} / \mathrm{mL}$, and no difference in IgG avidity. ${ }^{27}$

Crum-Cianflone et al. randomized 131 HIV-positive participants to be revaccinated with PNEU-C-7 and 73 to PNEU-P-23, 3-8 years after their previous dose of PNEU-P-23. Twenty-five HIV-negative participants who were previously unvaccinated received PNEU-C-7. The median CD4 count was 533 and 513 cells $/ \mathrm{mm} 3$ in the PNEU-C-7 and the PNEU-P-23 group, respectively. Participants in the PNEU-C-7 group were more likely to be on HAART (84.7\% vs. 56\%).

The proportion of subjects with a 2-fold increase in their lgG titers at day 60 for 2 of 4 serotypes (4, 9V, 14, 19F) was higher in the group revaccinated with PNEU-C-7 (57\%), compared to PNEU-P-23 (36\%); $p=0.004$. The proportion of respondent in HIV-negative participants was $88 \%$. In HIV-infected participants, the adjusted OR (adjusted for CD4 count, age, ethnicity, prior pneumonia, HAART at baseline, and HIV viral load) for response to 2 of 4 serotypes, when comparing PNEU-C-7 and PNEU-P-23 was $2.6(95 \% \mathrm{Cl} 1.4-5.0) .{ }^{28}$

Lesprit et al. randomized 212 HIV-positive patients with CD4 counts between 200-500 cells/ $\mu$ l to receive either PNEU-C-7/ PNEU-P-23 $(n=106)$ or PNEU-P-23 alone. Baseline IgG titers and characteristics were similar in both groups. Four weeks after the last vaccine dose, IgG titers were similar in both groups except for an improved response after PNEU-C-7/ PNEU-P-23 for serotypes $18 \mathrm{C}$ and 23F. At week 24, IgG titers were higher in the PNEU-C-7/PNEU-P-23 group for 4 of 7 serotypes. There was a higher proportion of subjects with a response (2-fold increase in IgG levels and a minimum level of $1 \mathrm{mg} / \mathrm{L}$ ) to 5 of 7 serotypes in the prime-boost arm: with a $59 \%$ response vs. $40 \%$ in the PNEU-P-23 alone; $p=0.005$. The same was found at 24 weeks: $30 \%$ vs. $10 \%$ responded to 5 of 7 serotypes in the prime-boost and PNEU-P-23 group, respectively $(p=0.003){ }^{29}$

\section{Elderly population}

Two multicenter studies looked at the immunogenicity of the concomitant administration of the trivalent influenza vaccine (TIV) with PNEU-C-13 in healthy participants, previously not immunized with any pneumococcal vaccine, aged 50-59 years (U.S. study) $)^{30}$ and 65 years and over (European study) $)^{31}$ These studies compared the administration of PNEU-C-13/ TIV followed 1 month later by placebo vs. TIV/placebo followed 1 month later by PNEU-C-13. No comparison was made with PNEU-P-23. Schwarz et al. reported 13 serotypes GMCs between 1.08 (serotype 3) and 11.93 (19A) $\mu \mathrm{g} / \mathrm{mL}$ in the concomitant group and between 1.15 (3) and 17.10 (19A) $\mu \mathrm{g} / \mathrm{mL}$ when PNEU-C-13 was administered alone, with GMC ratios (concomitant/PNEU-C-13 alone) $<1.0$ - all reaching the pre-determined non-inferiority criterion except for serotype 19F. Response to TIV was similar in both groups.31 Similarly, Frenck et al. reported GMCs between 1.15 (serotype 3) and 16.80 (19A) $\mu \mathrm{g} / \mathrm{mL}$ in concomitant group and between 1.46 (3) and $18.84(19 \mathrm{~A}) \mu \mathrm{g} / \mathrm{mL}$ when PNEU-C-13 was administered alone. OPA GMTs were between 61 (serotype 3) and 2421 (6B) in the concomitant group and between 78 (3) and 3215 (6B) when PNEU-C-13 was administered alone. In this study, although GMC ratios were all $<1$, all serotypes reached the non-inferiority criterion. However, for OPA GMT ratios, all were also <1; and 5 of 13 serotypes (1, 5, 7F, 9V, and 19F) did not met the non-inferiority criterion (lower bound of $95 \% \mathrm{Cl}<0.5) .30$ 
Jackson et al randomized healthy adults aged 70 to 79 years, who had received PNEU-P-23 at or after their 65th birthday (at least 5 years before the study) to receive either a dose of PNEU-P-23 or PNEU-C-7 at doses of 0.5 , 1, or $2 \mathrm{~mL}$. Post vaccination titers were significantly higher with the $2-\mathrm{mL}$ dose compared to $0.5-\mathrm{mL}$ dose for 3 of 7 serotypes (6B, 9V, 23F) and significantly higher with the $1-\mathrm{mL}$ and $2-\mathrm{mL}$ dose, compared to $0.5 \mathrm{~mL}$ for serotypes $18 \mathrm{C}$ and 19 . One year after vaccination, GMC for all serotypes were similar to pre-vaccine titers, regardless of vaccine and dose administered. There was no significant difference in GMC between PNEU-C-7 $(0.5 \mathrm{~mL})$ and PNEU-P-23; however, once adjusted for baseline GMC, 2 serotypes met criteria for superior immunogenicity in the PNEU-C-7 group. OPA GMTs were significantly higher after PNEU-C-7 $(0.5 \mathrm{~mL})$ compared to PNEU-P-23 for serotypes $9 \mathrm{~V}$ and $23 \mathrm{~F}$. However, there was no significant difference in OPA GMTs 1 year after the vaccine. ${ }^{32}$

De Roux et al. randomized 219 adults aged 70 years and over to receive either PNEU-C-7 $(n=110)$ or PNEU-P-23 $(n=109)$ as their first dose, followed one year later with either PNEU-C-7 or PNEU-P-23 for participants who had received PNEU-C-7 as their first vaccine dose, or PNEU-C-7 if the first dose was PNEU-P-23. Serotype specific IgG titers were significantly higher one month after a single dose of PNEU-C-7 compared with PNEU-P-23. Titers were significantly lower in the group who received PNEU-P-23 followed 1 year later by PNEU-C-7 when measured one month after PNEU-C-7 compared to the group that received a single dose of PNEU-C-7. There was no added benefit in a second dose of PNEU-C-7 one year after a primary PNEU-C-7 dose. OPA GMTs followed the same trends as IgG titers. ${ }^{33}$

Miernyk et al. randomized Alaskan Natives aged 55-70 years, who were not previously vaccinated against pneumococcus, to receive either PNEU-P-23 ( $n=28)$, PNEU-C-7 followed 2 months later by PNEU-P-23 $(n=29)$, or PNEU-C-7 followed 6 months later by PNEU-P-23 $(n=29)$. Baseline characteristics of all groups were similar. There was a significant increase in GMCs to all vaccine serotypes compared to baseline among the 3 groups (PNEU-P-23 [1 group] and PNEU-C-7 [2 groups]) and the increase was similar for the 3 groups except for serotype 1 (higher after PNEU-P-23). Two months after the final dose, there was no difference in GMCs for all serotypes among the 3 groups. OPA titers 1 month after the 1st dose and 2 months after the final dose were similar for the 3 groups. ${ }^{34}$

Goldblatt et al. randomized patients aged 50 to 80 years who were not vaccinated against pneumococcus in the previous 5 years to receive either PNEU-C-7 and PNEU-C-7
6 months later $(n=133)$; PNEU-C-7 and PNEU-P-23 6 months later $(n=171)$, PNEU-P-23 $(n=159)$, or PNEU-C-7 $(n=136)$. One month after PNEU-C-7 or PNEU-P-23, serotypes 4, 9, and 23F had higher GMCs after PNEU-C-7; however, one year after vaccination, there was no significant difference between the 2 groups for 6 of 7 serotypes (23F had higher GMC after PNEU-P-7). One month after the 2nd dose, there was no difference in GMCs for 6 of 7 serotypes (19F had higher GMC after PNEU-C-7/PNEU-P-23 compared with PNEU-C-7/PNEU-C-7). One year after PNEU-C-7/PNEU-C-7 vs. PNEU-P-23, the proportion of subjects with serotypespecific antibody concentrations $>1 \mu \mathrm{g} / \mathrm{mL}$ was not different. ${ }^{35}$

Schenkein et al. randomized 45 adults aged $<45$ years and 58 adults aged 65 years and over to receive PNEU-P-23.

There was no difference in GMC found between the younger and the older age groups. However, there was a significantly higher antibody potency (opsonization titers) for all serotypes in the younger age group. ${ }^{36}$

Musher et al. randomized adults who were either previously vaccinated (no minimal interval between previous dose of PNEU-P-23 and study enrolment) or not vaccinated with PNEU-P-23, aged 50-65 years and 65 years and over, to receive PNEU-P-23 or placebo. They reported that, for all serotypes, except 8 and 14 in the 65 years and over and 14 in the 50-65 years, there was no significant difference in IgG titers between groups who were vaccinated for the first time and the group that was being revaccinated, when measured at 30 and 60 days. ${ }^{37}$

\section{IV.5 VACCINE ADMINISTRATION AND SCHEDULE}

The dose of PNEU-C-13 for adults is $0.5 \mathrm{~mL}$ administered IM once, followed 8 weeks later by PNEU-P-23 for patients at high-risk of IPD. HSCT recipients should receive a priming series composed of 3 doses of PNEU-C-13 given at least 4 weeks apart. The exact timing of the series initiation should be assessed on a case-by-case basis and discussed with hemato-oncologists. The literature shows that this priming series can be started between 3 and 9 months after HSCT. This primary series should be boosted with one dose of PNEU-P-23 given 6 to 12 months later.

\section{IV.6 SEROLOGICAL TESTING}

There is no indication for routine pre- or post-immunization serology. 


\section{IV.7 STORAGE REQUIREMENTS}

The vaccine should be refrigerated, with the temperature maintained between $2^{\circ} \mathrm{C}$ to $8^{\circ} \mathrm{C}$. Vaccine, which has been frozen, should be discarded. In cases of temporary breaks in the cold chain, PNEU-C-13 has been shown to be stable at temperatures up to $40^{\circ} \mathrm{C}$ for up to 4 days. ${ }^{38}$ However, practitioners should adhere to usual provincial procedures for deciding on vaccine viability following breaks in the cold chain.

\section{IV.8 SIMULTANEOUS ADMINISTRATION WITH OTHER VACCINES}

PNEU-C-13 has only been administered concomitantly with TIV in the adult population ${ }^{30,31}$ and seemed to provide a similar response to TIV, whether PNEU-C-13 was given concomitantly or alone. PNEU-C-13 serotype specific titers were not different when given alone or concomitantly in most instances. One study showed a decrease in OPA GMTs when PNEU-C-13 was given with TIV but the clinical implications for these findings are unclear.

PNEU-C-13 has been studied when given concomitantly with a number of vaccine antigens used in a childhood schedule in Canada with no adverse effect on immunogenicity or safety profile. These antigens include: diphtheria, tetanus, acellular pertussis, Haemophilus influenzae type b, inactivated poliomyelitis, hepatitis $B$, meningococcal serogroup $C$, measles, mumps, rubella and varicella. ${ }^{39}$ As with general guidance given for all vaccines, PNEU-C-13 should be administered at a different site than concomitantly administered vaccines, using a different needle and syringe.

\section{IV.9 ADVERSE EVENTS}

PNEU-C-13 was administered to 2,276 adults aged 50 years and over in two distinct studies. A total of 943 received PNEU-C-13 alone; 453 aged $50-59$ years and 470 aged 65 years and older. In these participants, 607/926 (66\%) reported a local reaction, the most frequent being pain at the injection site in 587/923 (64\%) of participants. Systemic adverse events (any) were reported in 562/912 (62\%) of participants, with fatigue (305/795; 38\%), headache (283/787; 36\%), and new onset myalgia $(312 / 798 ; 39 \%)$ being the most frequent. Fever (38 degrees $C$ and higher) was reported in 21/663 (3\%) of participants. ${ }^{30,31}$

Safety was assessed in 6 clinical trials (including the 2 trials previously described)38: PNEU-C-13 was administered to 5,667 adults; 2,616 adults were aged 50 to 64 years and 3,051 adults were 65 years and older. Of the PNEU-C-13 recipients, 1,916 adults were previously vaccinated with
PNEU-P-23 at least 3 years prior, and 3,751 adults had never been vaccinated with PNEU-P-23. The results are summarized below:

\section{Local reactions ${ }^{38}$ :}

In adults aged 50-59 years, previously unvaccinated with PNEU-P-23, pain at injection site was the most frequently reported adverse event (88.8\%) but in the majority of cases (85.9\%), pain was mild in intensity. Other reported local adverse events were: limitation of arm movement (40.7\% - majority was mild in intensity), swelling (21.7\%), and redness (15.8\%).

In adults aged 60-64 years, previously unvaccinated with PNEU-P-23, pain was reported in $80.1 \%$ and $69.2 \%$ of participants (2 different studies), which was higher than after PNEU-P-23 (73.4\% and 58.3\%). Pain was mainly mild in intensity. Limitation of arm movement was reported in $28.5 \%$ and $23.5 \%$ (lower than after PNEU-P-23), redness in $20.2 \%$ and $12.2 \%$, and swelling in $19.3 \%$ and $10 \%$.

In adults aged 68 years and over, previously vaccinated with PNEU-P-23, pain was reported in $51 \%$, limitation of arm movement in $16.2 \%$, redness in $14.3 \%$, and swelling in $12.8 \%$. In adults aged 70 years and over, previously vaccinated with PNEU-P-23, pain was reported in 51.7\%, limitation of arm movement in $10.5 \%$, redness in $10.8 \%$, and swelling in 10,4\% - significantly lower than after PNEU-P-23 for limitation of arm movement (27.6\%), redness (22.2\%), and swelling (23.1\%).

\section{Systemic events ${ }^{38}$ :}

In adults aged 50-59 years, previously unvaccinated with PNEU-P-23, headache was the most commonly reported event (65.9\%), followed by fatigue (63.3\%), myalgia (61.8\%), arthralgia (31.5\%), anorexia (25.3\%), chills (19.6\%), and rash (14.2\%).

In the two studies done in adults aged 60-64 years who were previously unvaccinated with PNEU-P-23, fatigue was reported in $63.2 \%$ and $50.5 \%$, headache in $54 \%$ and $49.7 \%$, myalgia in $56.2 \%$ and $46.9 \%$, arthralgia in $24.4 \%$ and $15.5 \%$, chills in $23.5 \%$ and $19.9 \%$, and rash in $16.5 \%$ and $8.6 \%$ in the 2 studies respectively. In one study, the proportion of adverse events reported after PNEU-C-13 does not differ from those reported after PNEU-P-23. In the second study, arthralgia (23.8\%) and anorexia (23\%) were reported more commonly after PNEU-P-23 than after PNEU-C-13. 
In adults aged 68 years and over, previously vaccinated with PNEU-P-23, fatigue was reported in $34.4 \%$, headache in $26.1 \%$, myal gia in $25.3 \%$, diarrhea in $14.5 \%$, arthralgia in $12.8 \%$, anorexia in $11.2 \%$, rash in $8.4 \%$, and chills in $7.5 \%$. In adults aged 70 years and over, previously vaccinated with PNEU-P-23, myalgia was reported in $36.8 \%$, fatigue in $34 \%$, headache in $23.7 \%$, arthralgia in $12.6 \%$, anorexia in $10.4 \%$, chills in $7.9 \%$, and rash in $7.3 \%$. The following were solicited adverse events that occurred significantly more commonly following PNEU-P-23 in the same study: fatigue (43.3\%), myalgia (44.7\%), and rash (16.4\%).

Any fever was reported in 1.1 to $4.2 \%$ of participants after PNEU-C-13, compared to 1.1 to $2.3 \%$ of participants after PNEU-P-23. Most fever episodes were between 38-38.50C.

\section{IV.10 CONTRAINDICATIONS AND PRECAUTIONS}

PNEU-C-13 is contraindicated in any individual with a history of anaphylaxis to any component of the vaccine, including diphtheria toxoid.

\section{Summary}

The evidence reviewed show improved immune response of pneumococcal conjugate vaccines compared to PNEU-P-23 for adults who have undergone a HSCT; the evidence for SOT is not as compelling. PNEU-P-23 VE in HIV-positive subjects is low - at best - but most often not protective, whereas PNEU-C-7 has shown better protection. There is no efficacy or effectiveness study on the use of pneumococcal conjugate vaccines in the elderly and results from immunogenicity studies that compared the use of PNEU-C-7 and PNEU-P-23 showed similar antibody titers one year after vaccination for the seven common serotypes. There is currently no published immunogenicity study comparing the use of PNEU-C-13 and PNEU-P-23 in the elderly population and no established correlates of protection to allow for the interpretation of immunogenicity results in this population.

\section{Recommendations}

Please note that provinces and territories must consider economic factors and other local programmatic/operational factors when considering inclusion of the following recommendations in publicly funded immunization programs.

\section{As new data become available, these recommendations will be reviewed and updated.}

\section{Recommendation \#1:}

$\mathrm{NACl}$ concludes that there is good evidence to recommend the use of PNEU-C-13 for HSCT recipients given the improved immunogenicity of pneumococcal conjugate vaccines compared to PNEU-P-23 in HSCT recipients. HSCT recipients should receive a primary series of 3 doses of PNEU-C-13 starting 3-9 months after transplant, after discussion with transplant specialists. The primary series ( 3 doses) should be administered at least 4 weeks apart, followed by a booster dose of PNEU-P-23 12 to 18 months post transplant (6 to 12 months after the last dose of PNEU-C-13). (NACl recommendation $\mathrm{A}$ )

\section{Recommendation \#2:}

$\mathrm{NACl}$ concludes that there is good evidence to recommend the use of PNEU-C-13 for HIV-positive patients given the improved efficacy and effectiveness of pneumococcal conjugate vaccine (PNEU-C-7) in HIV-positive subjects. HIV-positive subjects should receive one dose of PNEU-C-13 followed 8 weeks later by one dose of PNEU-P-23. There is currently no evidence that a PNEU-C-13 booster dose adds any benefit. ( $\mathrm{NACl}$ recommendation $\mathrm{A}$ )

Most published studies excluded participants who had received a dose of PNEU-P-23 in the 5 years preceding study enrolment. Therefore data on the minimal interval between a previous PNEU-P-23 dose and PNEU-C-13 is unknown. However, given the potential for decrease in antibody titers following PNEU-P-23, severity of IPD in immunocompromised individuals, and benefits from PNEU-C-13 in this patient population, NACl recommends to administer PNEU-C-13 at least one year after any previous dose of PNEU-P-23. (Experts' opinions)

Re-immunization with one lifetime booster dose of PNEU-P-23 is recommended for those at highest risk of IPD, i.e. HIV-positive individuals. HIV-positive patients who previously received PNEU-P-23 and who require an additional dose of PNEU-P-23 should therefore receive it no sooner than 8 weeks after PNEU-C-13 and no sooner than 5 years after the most recent dose of PNEU-P-23. (Experts' opinion) 


\section{Recommendation \#3:}

$\mathrm{NACl}$ concludes that there is currently fair evidence to recommend the use of PNEU-C-13 for subjects with other immunocompromising conditions including:

- Asplenia (anatomical or functional)

- Sickle cell disease or other hemoglobinopathies

- Congenital immunodeficiencies involving any part of the immune system, including B-lymphocyte (humoral) immunity, T-lymphocyte (cell) mediated immunity, complement system (properdin, or factor D deficiencies), or phagocytic functions

- Immunosuppressive therapy including use of long term corticosteroids, chemotherapy, radiation therapy, postorgan-transplant therapy, biologic and non-biologic immunosuppressive therapies for rheumatologic and other inflammatory diseases.

- Malignant neoplasms including leukemia and lymphoma

- Solid organ or islet cell transplant (candidate or recipient).

These immunocompromised patients should receive one dose of PNEU-C-13 followed 8 weeks later by one dose of PNEU-P-23. There is currently no evidence that a PNEU-C13 booster dose adds any benefit. (NACl recommendation $\mathrm{B}$ )

Published studies excluded participants who had received a dose of PNEU-P-23 in the 5 years preceding study enrolment. Therefore data on the minimal interval between a previous PNEU-P-23 dose and PNEU-C-13 is unknown. However, given the potential for decrease in antibody titers following PNEU-P-23, severity of IPD in immunocompromised individuals, and benefits from PNEU-C-13 in this patient population, $\mathrm{NACl}$ recommends to administer PNEU-C-13 at least one year after any previous dose of PNEU-P-23. (Experts' opinions)

Re-immunization with one lifetime booster dose of PNEU-P-23 is recommended for those at highest risk of IPD, i.e. those with functional or anatomic asplenia or sickle cell disease; and immunosuppression related to disease or therapy, including solid organ transplant recipients. Individuals from these high-risk categories who have previously received PNEU-P-23 and who require an additional dose of PNEU-P-23 should therefore receive it no sooner than 8 weeks after PNEU-C-13 and no sooner than 5 years after the most recent dose of PNEU-P-23. (Experts' opinion)

There are currently no available studies for all of the abovementioned conditions. However, based on data from solid organ transplants recipients, the recommendation has been generalized to other immunosuppressed individuals.

\section{Recommendation \#4:}

$\mathrm{NACl}$ concludes that there is currently insufficient evidence to recommend the use of PNEU-C-13 in patients with chronic conditions without immunosuppression (listed below). However, other factors may influence decisionmaking. Recommendations for vaccination with PNEU-P-23 have not changed. (NACl recommendation I)

Patients with chronic conditions without immunosuppression include:

- Chronic CSF leak

- Cochlear implants

- Chronic neurologic condition that may impair clearance of oral secretions

- Chronic cardiac or pulmonary disease

- Diabetes mellitus

- Chronic kidney disease, including nephrotic syndrome

- Chronic liver disease (including hepatitis B and C, and hepatic cirrhosis due to any cause)

\section{Recommendation \#5:}

$\mathrm{NACl}$ concludes that there is currently insufficient evidence to recommend the use of PNEU-C-13 in healthy adults aged 65 years and over. However, other factors may influence decision-making. Recommendations for vaccination with PNEU-P-23 have not changed. (NACl recommendation I)

$\mathrm{NACl}$ considers that the following critical information is currently missing to allow for a recommendation of PNEU-

C-13 use in healthy adults aged 65 and over:

1. Efficacy or effectiveness data - in comparison to placebo and ideally PNEU-P-23 - on the ability of PNEU-C-13 to prevent IPD in this population

2. Efficacy or effectiveness data - in comparison to placebo and ideally PNEU-P-23 - on the ability of PNEU-C-13 to prevent community-acquired pneumonia in this population

3. Correlates of protection that would allow for the interpretation of immunogenicity data that are currently available for PNEU-C-13

4. The indirect protection provided by the infant and childhood PNEU-C-13 program on IPD and serotypes causing IPD in the adult population. 


\section{Surveillance and Research Priorities}

The epidemiology of invasive pneumococcal disease is changing in Canada and elsewhere, both due to and independent of the use of pneumococcal vaccines. Ongoing changes are expected as PNEU-C-13 vaccines are used routinely in childhood vaccination programs. Nationwide surveillance systems to detect these changes over time are essential. Optimal decisions about the use of pneumococcal vaccines requires ongoing surveillance for serotype-specific rates of invasive pneumococcal disease, and other disease syndromes, serotype-specific estimates of the efficacy of different vaccines, and continuing assessment of the effectiveness and cost-effectiveness of different vaccination schedules over time.

Surveillance and research which addresses the following outstanding questions is particularly encouraged:

- What is the efficacy and effectiveness of PNEU-C-13 in adults in the prevention of IPD or community-acquired pneumonia, compared to PNEU-P-23?
- What is the impact of conjugate pneumococcal vaccines use on IPD in adults aged 65 years and overin particular in terms of serotypes involved?

- What is the serotype-specific efficacy and effectiveness of PNEU-C-13?

- What antibody concentrations, or other immunologic markers, correlate best with protection against invasive pneumococcal disease, pneumococcal pneumonia, acute otitis media and nasopharyngeal carriage?

- Will serotype replacement offset the benefits of pneumococcal conjugate vaccine use in children?

- What are the determinants of indirect protection of adults from pediatric vaccines?

- What factors other than immunization influence changes in the incidence of disease due to different serotypes over time?

- Does previous vaccination with PNEU-P-23 impact the effectiveness of PNEU-C-13 in adults?

- Is there a need for a booster dose of PNEU-C-13 or PNEU-P-23 in adults? 


\section{Tables}

TABLE 5. Summary of Evidence for NACI Recommendation(s):

\begin{tabular}{|c|c|c|c|c|c|c|}
\hline \multicolumn{7}{|c|}{ Evidence for Efficacy } \\
\hline \multicolumn{5}{|c|}{ STUDY DETAILS } & \multicolumn{2}{|c|}{ SUMMARY } \\
\hline Study & Vaccine & Study Design & Participants & $\begin{array}{l}\text { Summary of Key Findings Using } \\
\text { Text or Data }\end{array}$ & $\begin{array}{l}\text { Level of } \\
\text { Evidence }\end{array}$ & Quality \\
\hline French, 2010 (9) & $\begin{array}{l}\text { PNEU-C-7 vs. } \\
\text { Placebo } \\
\text { Patients } \\
\text { recruited } \\
\text { from Queen } \\
\text { Elizabeth } \\
\text { central } \\
\text { hospital in } \\
\text { Malawi }\end{array}$ & $\begin{array}{l}\text { Double-blind, } \\
\text { randomized } \\
\text { controlled trial } \\
\text { Length of follow-up: } \\
\text { Feb 2003- } \\
\text { October } 2007 \\
\text { (median: } 1.2 \text { year) } \\
\text { HIV+ adolescent } \\
\text { and adults who } \\
\text { had recuperated } \\
\text { from IPD episode }\end{array}$ & $\begin{array}{l}496 \text { patients of } \\
\text { whom } 439 \text { were } \\
\text { HIV+ were } \\
\text { randomly } \\
\text { assigned to } \\
\text { receive two } \\
\text { doses of vaccine } \\
\text { or placebo four } \\
\text { weeks apart } \\
\text { Vaccine group } \\
\mathrm{N}=248 \text {, Age } \\
\text { Complete } \\
\text { follow-up } \\
\text { available on } 239 \\
\text { HIV+ patients }\end{array}$ & $\begin{array}{l}\text { Endpoint: New episode of IPD } \\
\text { from one of the vaccine serotypes } \\
+6 \mathrm{~A} \text { (in light of potential } \\
\text { cross-protection) } \\
\text { Primary endpoint ( } 1 \text { st episode of IPD } \\
\text { of vaccine serotypes or } 6 \mathrm{~A})-\mathrm{ITT} \text { : } \\
\text { HR (adjusted) }=0.31(0.11-0.84) \\
\text { VE (adjusted) }=0.69(0.16-0.89) \\
\text { Per-protocol: HR (adjusted) }=0.26 \\
(0.08-0.78)\end{array}$ & Level I & Good \\
\hline
\end{tabular}

\begin{tabular}{|c|c|c|c|c|c|c|}
\hline \multicolumn{7}{|c|}{ Evidence for Effectiveness } \\
\hline \multicolumn{5}{|c|}{ STUDY DETAILS } & \multicolumn{2}{|c|}{ SUMMARY } \\
\hline Study & Vaccine & Study Design & Participants & $\begin{array}{l}\text { Summary of Key Findings Using } \\
\text { Text or Data }\end{array}$ & $\begin{array}{l}\text { Level of } \\
\text { Evidence }\end{array}$ & Quality \\
\hline French, 2010 (9) & $\begin{array}{l}\text { PNEU-C-7 vs. } \\
\text { Placebo } \\
\text { Patients } \\
\text { recruited } \\
\text { from Queen } \\
\text { Elizabeth } \\
\text { central } \\
\text { hospital in } \\
\text { Malawi }\end{array}$ & $\begin{array}{l}\text { Double-blind, } \\
\text { randomized } \\
\text { controlled trial } \\
\text { Length of } \\
\text { follow-up: Feb } \\
2003 \text {-October } \\
2007 \text { (median: } 1.2 \\
\text { year) } \\
\text { HIV+ adolescent } \\
\text { and adults who } \\
\text { had recuperated } \\
\text { from IPD episode }\end{array}$ & $\begin{array}{l}496 \text { patients of } \\
\text { whom } 439 \text { were } \\
\text { HIV+ were } \\
\text { randomly } \\
\text { assigned to } \\
\text { receive two } \\
\text { doses of vaccine } \\
\text { or placebo four } \\
\text { weeks apart } \\
\text { Vaccine group } \\
\text { N=248, Age } \\
\text { Complete } \\
\text { follow-up } \\
\text { available on } 239 \\
\text { HIV+ patients }\end{array}$ & $\begin{array}{l}\text { Endpoint: New episode of IPD } \\
\text { from one of the vaccine serotypes } \\
+6 \mathrm{~A} \text { (in light of potential } \\
\text { cross-protection) } \\
\text { Primary endpoint (1 st episode } \\
\text { of IPD of vaccine serotypes or } \\
6 A)- \text { ITT: HR (adjusted) }=0.31 \\
\text { (0.11-0.84) } \\
\text { VE (adjusted) }=0.69(0.16-0.89) \\
\text { Per-protocol: HR (adjusted) }=0.26 \\
(0.08-0.78)\end{array}$ & Level I & Good \\
\hline
\end{tabular}




\begin{tabular}{|c|c|c|c|c|c|c|}
\hline \multicolumn{7}{|c|}{ Evidence for Effectiveness } \\
\hline \multicolumn{5}{|c|}{ STUDY DETAILS } & \multicolumn{2}{|c|}{ SUMMARY } \\
\hline Study & Vaccine & Study Design & Participants & $\begin{array}{l}\text { Summary of Key Findings Using } \\
\text { Text or Data }\end{array}$ & $\begin{array}{l}\text { Level of } \\
\text { Evidence }\end{array}$ & Quality \\
\hline $\begin{array}{l}\text { Breiman, } \\
2000 \text { (11) }\end{array}$ & $\begin{array}{l}\text { PNEU-P-23 } \\
\text { Dose:n/a } \\
\text { Route: n/a } \\
\text { Schedule: } \\
\text { n/a }\end{array}$ & $\begin{array}{l}\text { Retrospective } \\
\text { matched case- } \\
\text { control study } \\
\text { Study period: } \\
\text { Feb } 1992- \\
\text { April } 1995 \\
\text { Determination of } \\
\text { vaccination status: } \\
\text { physicians } \\
\text { contacted and } \\
\text { immunization } \\
\text { record obtained }\end{array}$ & $\begin{array}{l}\mathrm{N}=503 \\
\text { Cases: } 176 \\
\text { HIV-infected } \\
\text { adults hospitalized } \\
\text { with IPD } \\
\text { Controls = } 327 \\
\text { HIV-infected } \\
\text { adults admitted } \\
\text { to hospital, } \\
\text { matched on age, } \\
\text { hospital of } \\
\text { admission, CD4 } \\
\text { count, clinical } \\
\text { stage of HIV }\end{array}$ & 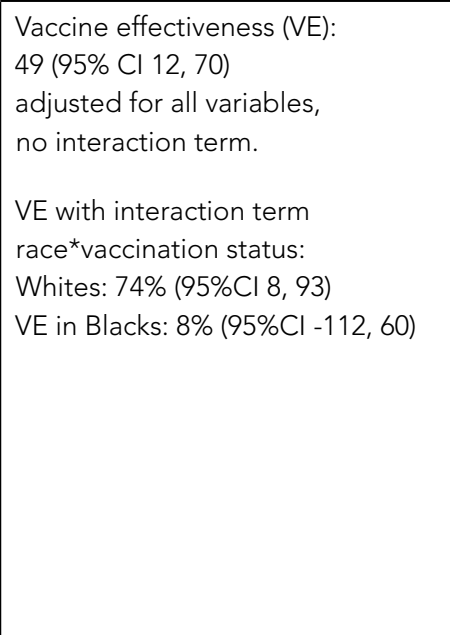 & Level II-2 & Good \\
\hline Hung, 2004 (12) & $\begin{array}{l}\text { PNEU-P-23 } \\
\text { Route: } n / a \\
\text { Dose: } n / a \\
\text { Schedule: } \\
\mathrm{n} / \mathrm{a}\end{array}$ & $\begin{array}{l}\text { Prospective } \\
\text { observational study } \\
\text { Length of } \\
\text { follow-up: } \\
641 \text { days in } \\
\text { vaccinees } \\
500 \text { days in } \\
\text { non-vaccinees } \\
\text { Period: } \\
1 \text { June } 2001- \\
31 \text { October } 2002\end{array}$ & $\begin{array}{l}\text { N1=305 } \\
\text { HIV-infected } \\
\text { vaccinated } \\
\text { Mean age: } 37 \\
\text { M/F: 280/25 } \\
\text { Baseline } \\
\text { CD4+<200: } \\
\text { 54.6\% } \\
\text { AIDS associated } \\
\text { oral infection } \\
\text { necessitating } \\
\text { antimicrobial } \\
\text { therapy: } 23.6 \% \\
\text { N2=203 } \\
\text { HIV-infected non } \\
\text { vaccinated } \\
\text { Mean age: } 33 \\
\text { M/F: 183/20 } \\
\text { Baseline CD4+ } \\
<200 \text { - 50.6\% } \\
\text { AIDS associated } \\
\text { oral infection } \\
\text { necessitating } \\
\text { antimicrobial } \\
\text { therapy: } 23.6 \% \\
\text { Setting: National } \\
\text { Taiwan University } \\
\text { Hospital }\end{array}$ & 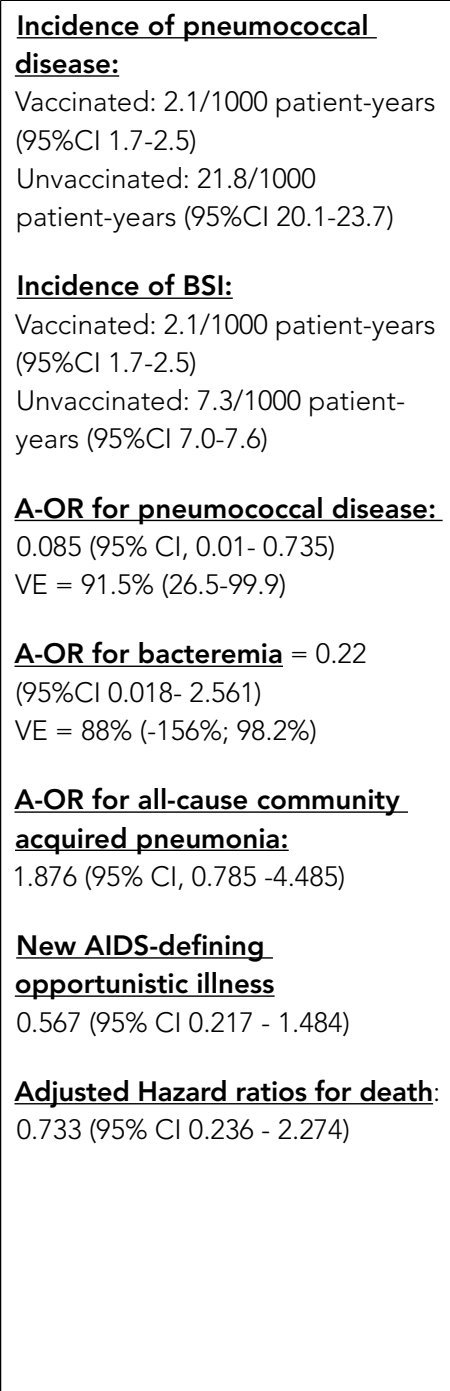 & Level II-2 & Good \\
\hline
\end{tabular}




\begin{tabular}{|c|c|c|c|c|c|c|}
\hline \multicolumn{7}{|c|}{ Evidence for Effectiveness } \\
\hline \multicolumn{5}{|c|}{ STUDY DETAILS } & \multicolumn{2}{|c|}{ SUMMARY } \\
\hline Study & Vaccine & Study Design & Participants & $\begin{array}{l}\text { Summary of Key Findings Using } \\
\text { Text or Data }\end{array}$ & $\begin{array}{l}\text { Level of } \\
\text { Evidence }\end{array}$ & Quality \\
\hline $\begin{array}{l}\text { French, } 2000 \\
\text { (13) }\end{array}$ & $\begin{array}{l}\text { PNEU-P-23 } \\
\text { vs. placebo }\end{array}$ & $\begin{array}{l}\text { Randomized, } \\
\text { placebo controlled } \\
\text { trial }\end{array}$ & $\begin{array}{l}\mathrm{N}=1392 \\
\text { HIV-infected } \\
\text { adults in } \mathrm{WHO} \\
\text { clinical stage } 1,2 \\
\text { or } 3 \text { randomized } \\
1: 1\end{array}$ & 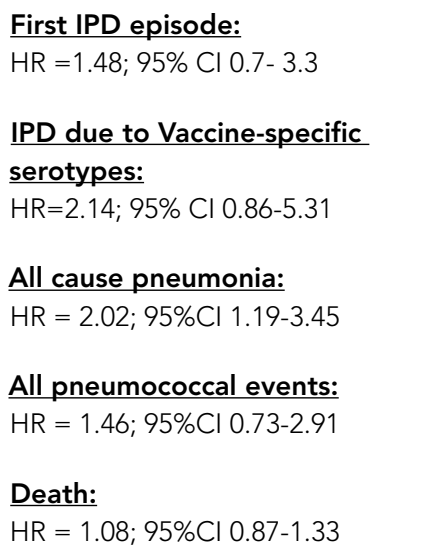 & Level I & Good \\
\hline $\begin{array}{l}\text { Vila-Corcoles, } \\
2005 \text { (14) }\end{array}$ & PNEU-P-23 & $\begin{array}{l}\text { Prospective cohort } \\
\text { study } \\
\text { Length of } \\
\text { follow-up: } \\
12 \text { months } \\
\text { Cohort of patients } \\
\text { followed in specific } \\
\text { clinics. } \\
\text { Outcomes } \\
\text { identified through } \\
\text { electronic } \\
\text { databases and } \\
\text { chart reviews }\end{array}$ & $\begin{array}{l}\mathrm{N}=11,241 \\
\text { Vaccinated } \\
\text { before entry = } \\
4986 \\
\text { Not vaccinated } \\
\text { before entry = } \\
6255 \\
\text { Vaccinated after } \\
\text { entry = } 720 \\
\text { Baseline } \\
\text { characteristics of } \\
\text { community- } \\
\text { dwelling subjects, } \\
\geq 65 \text { years } \\
\text { (vaccinated vs. } \\
\text { unvaccinated } \\
\text { prior to entry) } \\
\text { differed } \\
\text { significantly in } \\
\text { age, } \\
\text { comorbidities } \\
\text { and immune- } \\
\text { compromised } \\
\text { status were } \\
\text { significantly } \\
\text { greater in the } \\
\text { vaccinated group } \\
\text { than in the } \\
\text { unvaccinated } \\
\text { group. } \\
\text { Percentage of } \\
\text { smokers was } \\
\text { significantly } \\
\text { greater in the } \\
\text { unvaccinated } \\
\text { group. }\end{array}$ & $\begin{array}{l}\text { Adjusted Hazard Ratios for } \\
\text { primary endpoints: } \\
\text { Hospitalization for pneumonia } \\
\text { (adjusted sex, age, obesity, } \\
\text { chronic lung disease, immune- } \\
\text { compromised status and receipt or } \\
\text { non-receipt of influenza vaccine in } \\
\text { the previous year): } 0.81 \text { ( } 95 \% \mathrm{Cl} \\
0.51 \text { - } 1.30 \text { ); } p=0.387 \\
\text { Overall pneumonia } \\
\text { (adjusted for sex, age, chronic } \\
\text { cardiopathy, chronic lung disease, } \\
\text { immunocompromised status, } \\
\text { obesity and receipt of influenza } \\
\text { vaccine in the previous year): } 0.85 \\
\text { (95\% Cl } 0.56-1.31 \text { ); } p=0.467 \\
\text { Death from pneumonia } \\
\text { (adjusted for age, } \\
\text { immunocompromised status, } \\
\text { receipt of influenza vaccine in the } \\
\text { previous year): } 0.28 \text { ( } 95 \% \mathrm{Cl} 0.09 \text { - } \\
0.80) ; \mathrm{p}=0.018 \\
\text { Death from all causes } \\
\text { (adjusted for age, } \\
\text { immunocompromised status, } \\
\text { sex, chronic lung disease, } \\
\text { hypertension): } 0.67 \text { ( } 95 \% \mathrm{Cl} 0.54- \\
0.83 \text { ); } \mathrm{p}=0.000\end{array}$ & Level II-2 & Fair \\
\hline
\end{tabular}




\begin{tabular}{|c|c|c|c|c|c|c|}
\hline \multicolumn{7}{|c|}{ Evidence for Effectiveness } \\
\hline \multicolumn{5}{|c|}{ STUDY DETAILS } & \multicolumn{2}{|c|}{ SUMMARY } \\
\hline Study & Vaccine & Study Design & Participants & $\begin{array}{l}\text { Summary of Key Findings Using } \\
\text { Text or Data }\end{array}$ & $\begin{array}{l}\text { Level of } \\
\text { Evidence }\end{array}$ & Quality \\
\hline $\begin{array}{l}\text { Vila- Corcoles, } \\
2006 \text { (15) }\end{array}$ & $\begin{array}{l}\text { PNEU-P-23: } \\
\text { offered free } \\
\text { of charge to } \\
65 \text { years and } \\
\text { over but no } \\
\text { specific } \\
\text { campaign } \\
\text { Vaccine: } \\
\text { time- } \\
\text { dependent } \\
\text { variable }\end{array}$ & $\begin{array}{l}\text { Prospective cohort } \\
\text { study } \\
\text { Length of } \\
\text { follow-up: } \\
40 \text { month } \\
\text { Included all } \\
\text { community- } \\
\text { dwelling aged } \\
65 \text { years and over } \\
\text { assigned to } 1 \text { of } 8 \\
\text { primary health care } \\
\text { centers } \\
\text { Primary } \\
\text { outcomes: } \\
\text { IPD, CAP, } \\
\text { pneumococcal } \\
\text { pneumonia, death } \\
\text { occurring within } \\
30 \text { days from } \\
\text { pneumonia } \\
\text { Diagnostic } \\
\text { evaluations: } \\
\text { Blood and sputum } \\
\text { cultures, } \\
\text { serological testing } \\
\text { of paired sera, and } \\
\text { urinary antigen test } \\
\text { (as determined by } \\
\text { treating physician) } \\
\text { Pneumonia } \\
\text { Acute infiltrate on } \\
\text { CXR } \\
\text { Cases identified } \\
\text { using ICD-9 codes } \\
\text { (discharge } \\
\text { summaries) and } \\
\text { laboratory data }\end{array}$ & $\begin{array}{l}\text { Total cohort: } \\
11,241 \\
\mathrm{~N} \text { (vaccinated } \\
\text { prior to study) = } \\
4986 \\
\mathrm{~N} \text { (unvaccinated } \\
\text { before study) } \\
6255 \\
\text { All subjects were } \\
\geq 65 \text { year old } \\
\text { community } \\
\text { dwellers } \\
\text { Baseline } \\
\text { characteristics } \\
\text { between the two } \\
\text { groups were very } \\
\text { dissimilar. These } \\
\text { differences were } \\
\text { found in age } \\
\text { group } 65-74 \\
\text { years (46.2\% vs. } \\
62.4 \% \text {. }<<0.001 \text { ), } \\
\text { history of } \\
\text { hospitalization } \\
\text { for pneumonia in } \\
\text { previous } 2 \text { years } \\
\text { (1.7\% vs } 0.8 \% \text {; } \\
\text { p <0.01), rate } \\
\text { of influenza } \\
\text { vaccination in } \\
\text { previous year }\end{array}$ & 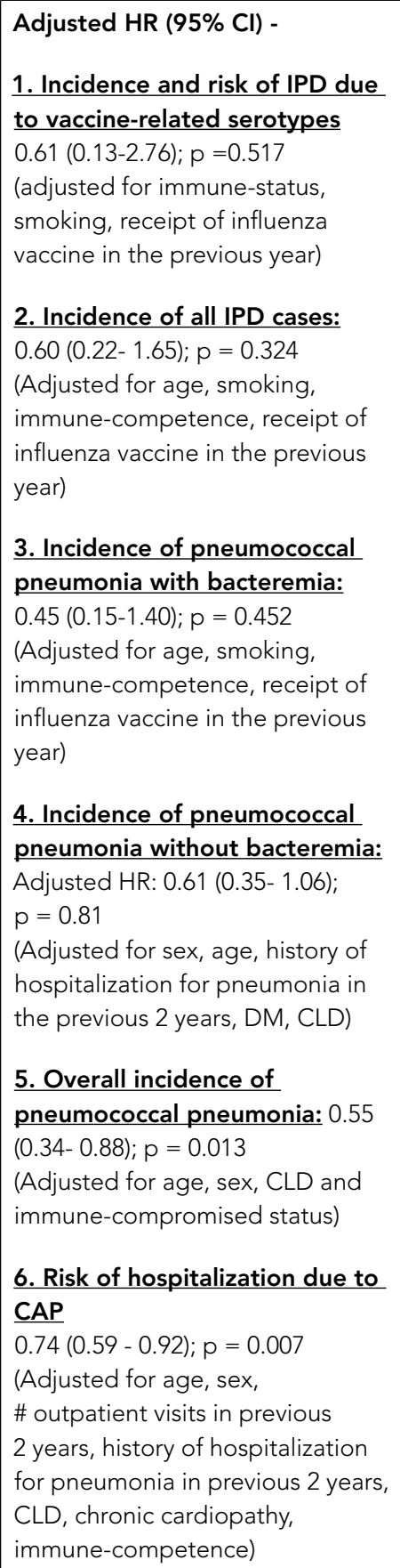 & Level II-2 & Good \\
\hline
\end{tabular}




\begin{tabular}{|c|c|c|c|c|c|c|}
\hline \multicolumn{7}{|c|}{ Evidence for Effectiveness } \\
\hline \multicolumn{5}{|c|}{ STUDY DETAILS } & \multicolumn{2}{|c|}{ SUMMARY } \\
\hline Study & Vaccine & Study Design & Participants & $\begin{array}{l}\text { Summary of Key Findings Using } \\
\text { Text or Data }\end{array}$ & $\begin{array}{l}\text { Level of } \\
\text { Evidence }\end{array}$ & Quality \\
\hline & & & & 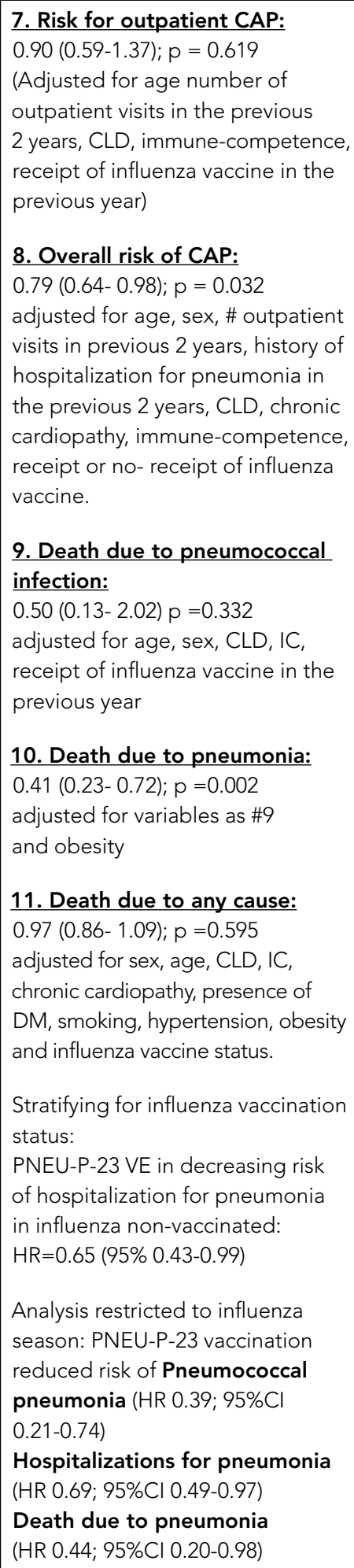 & & \\
\hline
\end{tabular}




\begin{tabular}{|c|c|c|c|c|c|c|}
\hline \multicolumn{7}{|c|}{ Evidence for Effectiveness } \\
\hline \multicolumn{5}{|c|}{ STUDY DETAILS } & \multicolumn{2}{|c|}{ SUMMARY } \\
\hline Study & Vaccine & Study Design & Participants & $\begin{array}{l}\text { Summary of Key Findings Using } \\
\text { Text or Data }\end{array}$ & $\begin{array}{l}\text { Level of } \\
\text { Evidence }\end{array}$ & Quality \\
\hline $\begin{array}{l}\text { Mooney, } 2008 \\
(16)\end{array}$ & PNEU-P-23 & $\begin{array}{l}\text { Retrospective } \\
\text { cohort design } \\
\text { Primary outcome } \\
\text { measure: Incidence } \\
\text { rates of IPD during } \\
\text { winter 2003/2004 in } \\
\text { the vaccine } \\
\text { targeted } \\
\text { population aged } \\
65 \text { and over. } \\
\text { Data extracted } \\
\text { from national HPS } \\
\text { database for IPD } \\
\text { cases } \\
\text { PNEU-P-23 uptake } \\
\text { estimated through } \\
\text { sentinel network } \\
\text { (7\% representative } \\
\text { sample of Scottish } \\
\text { population) } \\
\text { For each IPD case: } \\
\text { chart review } \\
\text { (primary care) } \\
\text { and postal } \\
\text { questionnaire }\end{array}$ & $\begin{array}{l}\text { N (IPD cases): } \\
396 \\
N \text { (IPD and }>\text { / } 65 \\
\text { years): } 170 \\
N \text { (IPD and } \geq 65 \\
\text { yrs + known } \\
\text { vaccination } \\
\text { status): } 145 \\
N \text { (IPD cases }+65 \\
\text { years vaccinated): } \\
63 \\
\text { No significant } \\
\text { difference in } \\
\text { incidence of IPD } \\
\text { among vaccine } \\
\text { recipients aged } \\
65+\text { years with or } \\
\text { without } \\
\text { respiratory } \\
\text { disease, } \\
\text { cardiovascular } \\
\text { disease or more } \\
\text { than one risk } \\
\text { factor. } \\
\% \text { male (all IPD): } \\
51.4 \\
\% \text { female (all IPD): } \\
36.7 \\
\text { Estimated } \\
\text { vaccine uptake: } \\
\text { Males } 68.1 \% \\
\text { Females } 65.5 \% \\
\text { a }\end{array}$ & $\begin{array}{l}\text { Age 65+ years: } \\
\text { Adjusted \% VE (excluding very } \\
\text { high risk): } 61.7 \text { (95\% Cl 45.1-73.2) } \\
\text { NNV: 5,206 (95\% Cl } 4388 \text { - 7122) } \\
\text { Age 65-74 years: } \\
\text { VE (excluding very high risk): } \\
54.4 \% \text { (95\% Cl 20.1- 74.0) } \\
\text { VE (male): } \\
41.0 \% \text { (95\% Cl -31.7 - 73.6) } \\
\text { VE (female): } \\
64.6 \% \text { (95\% Cl } 21.1 \text {-84.1) } \\
\text { Age 75+ years: } \\
\text { VE (excluding very high risk): } \\
68.8 \% \text { (95\% Cl } 52.0 \text { - 79.8) } \\
\text { VE (male): } \\
60.5 \% \text { (95\% Cl } 23.3 \text {-79.6) } \\
\text { VE (female): } \\
73.9 \% \text { (95\% Cl } 53.3 \text { - 85.4) } \\
\text { Adjusted RR of mortality } \\
\text { All age 65+ years: } 0.89 \text { (95\% Cl } \\
0.49 \text { - 1.63) } \\
\text { NNV to prevent } 1 \text { death: 14,810 }\end{array}$ & Level II-2 & Good \\
\hline
\end{tabular}




\begin{tabular}{|c|c|c|c|c|c|c|}
\hline \multicolumn{7}{|c|}{ Evidence for Effectiveness } \\
\hline \multicolumn{5}{|c|}{ STUDY DETAILS } & \multicolumn{2}{|c|}{ SUMMARY } \\
\hline Study & Vaccine & Study Design & Participants & $\begin{array}{l}\text { Summary of Key Findings Using } \\
\text { Text or Data }\end{array}$ & $\begin{array}{l}\text { Level of } \\
\text { Evidence }\end{array}$ & Quality \\
\hline $\begin{array}{l}\text { Melagaro, } \\
2004 \text { (17) }\end{array}$ & $\begin{array}{l}\text { PNEU-P-23 } \\
\text { Vs. Placebo }\end{array}$ & $\begin{array}{l}\text { Meta-analysis } \\
\text { Medline and } \\
\text { PubMed literature } \\
\text { search for studies } \\
\text { on PNEU-P-23 } \\
\text { efficacy without any } \\
\text { year or language } \\
\text { restriction. } \\
\text { Outcomes } \\
\text { evaluated: } \\
\text { Pneumococcal } \\
\text { pneumonia and } \\
\text { IPD }\end{array}$ & $\begin{array}{l}\text { Studies } \\
\text { included: } \\
\text { RCTs }=6 \\
\text { Quasi- } \\
\text { Randomized = } 3 \\
\text { High-risk } \\
\text { groups = 4 } \\
\text { Inclusion: } \\
\text { Randomized } \\
\text { and quasi- } \\
\text { randomized } \\
\text { controlled trials } \\
\text { with a well-defined } \\
\text { randomization } \\
\text { or quasi- } \\
\text { randomization } \\
\text { process; targeted } \\
\text { immune- } \\
\text { competent or } \\
\text { immune- } \\
\text { compromised } \\
\text { elderly }>50 \text { years, } \\
\text { assessing } \\
\text { pneumo-coccal } \\
\text { pneumonia and/ } \\
\text { or IPD } \\
\text { Two independent } \\
\text { reviewers; Use of } \\
\text { Jadad's scores }\end{array}$ & $\begin{array}{l}\text { VE against pneumococcal } \\
\text { pneumonia } \\
n \text { studies analyzed with this } \\
\text { end-point: } 7 \\
\text { Pooled VE estimates using } \\
\text { random effects model including } \\
\text { non-high-risk groups trials: } 16 \% \\
\text { (95\% Cl: -50-53\%) } \\
\text { Pooled VE estimates using } \\
\text { random effects model including } \\
\text { high-risk groups (HRG): -20\% } \\
\text { (-92-25\%) } \\
\text { Vaccine efficacy against IPD } \\
\text { Studies included: } 6 \\
\text { General population): } 2 \\
\text { HRG - randomized): } 4 \\
\text { HRG - quasi-randomized): } 2 \\
\text { Pooled VE estimate against IPD } \\
\text { in the general elderly population: } \\
65 \% \text { (-42-92\%) } \\
\text { Pooled VE estimate E against } \\
\text { IPD in HRG excluding quasi- } \\
\text { randomized: } 20 \% \text { (-187-78\%) } \\
\text { Pooled VE estimate against IPD in } \\
\text { HRG including quasi-randomized: } \\
44 \% \text { (-45-79\%) }\end{array}$ & Level I & Good \\
\hline
\end{tabular}




\begin{tabular}{|c|c|c|c|c|c|c|}
\hline \multicolumn{7}{|c|}{ Evidence for Immunogenicity } \\
\hline \multicolumn{5}{|c|}{ STUDY DETAILS } & \multicolumn{2}{|c|}{ SUMMARY } \\
\hline Study & Vaccine & Study Design & Participants & $\begin{array}{l}\text { Summary of Key Findings Using Text } \\
\text { or Data }\end{array}$ & $\begin{array}{l}\text { Level of } \\
\text { Evidence }\end{array}$ & Quality \\
\hline $\begin{array}{l}\text { Kumar, } 2008 \\
\text { (19) }\end{array}$ & $\begin{array}{l}\text { Placebo- } \\
\text { PNEU-P-23 } \\
\text { PNEU-C-7/ } \\
\text { PNEU-P-23 } \\
\text { Route: IM } \\
\text { Schedule: } \\
0 \text { weeks, } \\
8 \text { weeks } \\
\text { Dose: } 0.5 \mathrm{~mL} \\
\text { single dose }\end{array}$ & $\begin{array}{l}\text { Randomized- } \\
\text { double-blind, } \\
\text { Placebo-controlled } \\
\text { trial } \\
\text { Length of } \\
\text { follow-up: } 16 \\
\text { weeks } \\
\text { Power: } 80 \% \text { to } \\
\text { detect a } 25 \% \\
\text { difference } \\
\text { Response: } \geq 2 \text {-fold } \\
\text { increase and level } \\
\text { at least } 0.35 \mathrm{mg} / \mathrm{L}\end{array}$ & $\begin{array}{l}\mathrm{N}=130 \\
\mathrm{~N} 1=65 \\
\mathrm{~N} 2=65 \\
\text { Baseline } \\
\text { characteristics - } \\
\text { patients } \\
\text { post-liver } \\
\text { transplant } \geq \\
3 \text { months earlier; } \\
\text { PNEU-P-23 } \geq \\
5 \text { years prior. } \\
\\
\text { Previous } \\
\text { PNEU-P-23 (\%): } \\
8 \%, 14 \% \mathrm{P}=0.17 \\
\text { Prednisone (\%): } \\
\text { 28, 44 (P = 0.09) } \\
\text { Previous } \\
\text { anti-thymoglobulin } \\
\text { therapy } \\
\text { P = 0.064 } \\
\text { In multivariate } \\
\text { and univariate } \\
\text { analysis, } \\
\text { corticosteroid } \\
\text { use was } \\
\text { significantly } \\
\text { associated with } \\
\text { lower antibody } \\
\text { response } \\
\text { (OR = 5.0; 95\% } \\
\text { Cl 1.29 - 19.6; } \\
\text { P = 0.02) }\end{array}$ & $\begin{array}{l}\text { Immunogenicity } \\
\text { Response to at least } 1 \text { serotype of } \geq \\
2 \text { fold increase in titer from baseline } \\
\text { at } 16 \text { weeks: } \\
85.7 \% \text { vs. } 91.2 \% ; p=N S \\
\text { Mean number of serotypes to } \\
\text { respond at week } 16: \\
3.7 \pm 2.3 \text { vs., } 4.4 \pm 2.2 \text { ( } p=N S \text { ) } \\
\text { Response to each serotype at week } \\
\text { 16 (\%): } \\
48.2-76.8 \text { vs. } 36.8-64.9 \text { ( } p=N S \text { ) } \\
\text { Serotype-specific GMT at week } 16 \\
\text { ( } \mu \text { g/mL): } \\
\text { Serotype } 4: 0.67 \text { vs. } 1.24 ; p=0.25 \\
\text { Serotype } 6 B: 1.8 \text { vs. } 2.63 ; p=0.56 \\
\text { Serotype } 9 \mathrm{~V}: 2.37 \text { vs. } 1.96 ; p=0.28 \\
\text { Serotype } 14: 12.42 \text { vs. } 15.49 ; p=0.84 \\
\text { Serotype } 18 C: \text { : } 4.34 \text { vs. } 3.79 p=0.46 \\
\text { Serotype } 19 F: 4.95 \text { vs. } 5.10 ; p=0.78 \\
\text { Serotype } 23 \text { F: } 1.54 \text { vs. } 2.57 ; p=0.22 \\
\text { Opsonophagocytic activity } \geq 4 \text { fold } \\
\text { from baseline(\%): } 16.7-45.8 \text { vs. } \\
11.5-42.3 \text { ( } p=N S \text { for } 6 / 7 \text { serotypes) }\end{array}$ & Level I & Good \\
\hline
\end{tabular}




\begin{tabular}{|c|c|c|c|c|c|c|}
\hline \multicolumn{7}{|c|}{ Evidence for Immunogenicity } \\
\hline \multicolumn{5}{|c|}{ STUDY DETAILS } & \multicolumn{2}{|c|}{ SUMMARY } \\
\hline Study & Vaccine & Study Design & Participants & $\begin{array}{l}\text { Summary of Key Findings Using Text } \\
\text { or Data }\end{array}$ & $\begin{array}{l}\text { Level of } \\
\text { Evidence }\end{array}$ & Quality \\
\hline $\begin{array}{l}\text { Kumar, } 2003 \\
\text { (20) }\end{array}$ & $\begin{array}{l}\text { PNEU-C-7 } \\
\text { PNEU-P-23 } \\
\text { Dose = } 0.5 \mathrm{~mL} \\
\text { Route: IM } \\
\text { Study period: } \\
\text { Sept-Dec } \\
2001\end{array}$ & $\begin{array}{l}\text { Randomized } \\
\text { double-blind } \\
\text { Controlled trial } \\
\text { Length of } \\
\text { follow-up: } 8 \text { weeks } \\
\text { Renal transplant: } \\
3 \text { months to } 3 \text { years } \\
\text { post transplant } \\
\text { Exclusions: } \\
\text { splenectomy or } \\
\text { PNEU-P-23 in past } \\
5 \text { years }\end{array}$ & $\begin{array}{l}\mathrm{N}=60- \\
\text { Renal transplant } \\
\mathrm{N}=30 \\
\text { (PNEU-P-23) } \\
\mathrm{N}=30 \\
\text { (PNEU-C-7) } \\
\text { Baseline: } 2 \text { groups } \\
\text { similar in } \\
\text { demographic } \\
\text { and clinical } \\
\text { characteristics } \\
\text { including renal } \\
\text { function, time } \\
\text { since } \\
\text { transplantation } \\
\text { and } \\
\text { immune- } \\
\text { suppression. } \\
\text { Response: } \\
\text { ELISA: } \geq 2 \text {-fold } \\
\text { increase with } \\
\text { absolute titer of } \\
\text { at least } 1 \mu g / m L \\
\text { OPA: } \geq 4-f o l d \\
\text { increase with } \\
\text { absolute } \\
\text { value }>1: 8\end{array}$ & $\begin{array}{l}\text { Immunogenicity (IgG): } \\
\text { Serotype-specific GMT mean } \\
\text { fold-increase at } 8 \text { weeks compared } \\
\text { to baseline (PNEU-C-7 vs. PNEU-P-23): } \\
\text { Serotype } 4,6 B, 14,18 C, 19 F ; p=N S \\
\text { Serotype } 23 F: 16.8 \text { (range, } 0.8 \text { - 160) vs. } \\
2.2 \text { (range, } 0.4-23.5) ; p=0.046 \\
\text { Serotype } 9: 17 \text { vs. } 2.6, p=0.09 \\
\text { Proportion that responded (PNEU-C-7 } \\
\text { vs. PNEU-P-23): } \\
\text { Serotypes } 4,9 V, 18 C, 19 F: \text { PNEU-C-7> } \\
\text { PNEU-P-23; } p=N S \\
\text { Serotype } 23 F \text { (\%): } 40 \text { vs. } 16.7 ; p=0.046 \\
\text { Serotype } 6 B: 33.7 \text { vs. } 13.3 ; p=0.067 \\
\geq 1 \text { serotype (\%): } 53.3 \text { vs. } 73.3 \\
\text { Median number of serotypes } \\
\text { responding: } 1.0 \text { vs. } 2.5 ; p=0.069 \\
\text { Serotype-specific OPA titers -fold } \\
\text { increase: } \\
\text { No significant difference between two } \\
\text { groups for all } 7 \text { serotypes. } \\
\text { Serotype-specific OPA response rate: } \\
83.3 \text { vs. } 80 ; p=N S \\
\text { Median number of serotype-specific } \\
\text { OPA response: } \\
2.0 \text { vs. } 3.0 ; p=N S \text {. }\end{array}$ & Level I & Good \\
\hline
\end{tabular}




\begin{tabular}{|c|c|c|c|c|c|c|}
\hline \multicolumn{7}{|c|}{ Evidence for Immunogenicity } \\
\hline \multicolumn{5}{|c|}{ STUDY DETAILS } & \multicolumn{2}{|c|}{ SUMMARY } \\
\hline Study & Vaccine & Study Design & Participants & $\begin{array}{l}\text { Summary of Key Findings Using Text } \\
\text { or Data }\end{array}$ & $\begin{array}{l}\text { Level of } \\
\text { Evidence }\end{array}$ & Quality \\
\hline $\begin{array}{l}\text { Kumar, } 2007 \\
\text { (21) }\end{array}$ & $\begin{array}{l}\text { PNEU-C-7 } \\
\text { PNEU-P-23 } \\
\text { Original } \\
\text { dose: } 0.5 \mathrm{~mL}\end{array}$ & $\begin{array}{l}\text { Three-year follow } \\
\text { up prospective } \\
\text { cohort study of } \\
\text { a RCT } \\
\text { Renal transplant } \\
\text { patients } \\
\text { At } 3 \text { years, majority } \\
\text { of patients were } \\
\text { receiving } \\
\text { calcineurin- } \\
\text { inhibitors } \\
\text { (95.7\%) and } \\
\text { MMF (78.7\%) }\end{array}$ & $\begin{array}{l}60 \text { randomized } \\
\text { Renal transplant } \\
47 \text { analyzed= } \\
\text { PNEU-C-7 = } 23 \\
\text { PNEU-P-23 = } 24 \\
\text { 14: lost to } \\
\text { follow-up due } \\
\text { to refusal of } \\
\text { consent (7), } \\
\text { death (1), } \\
\text { unreachable (5) } \\
\text { Baseline } \\
\text { characteristics } \\
\text { between the two } \\
\text { groups were } \\
\text { similar with } \\
\text { respect to mean } \\
\text { age, gender, } \\
\text { time from } \\
\text { transplant, } \\
\text { imunonosuppres- } \\
\text { sion, graft loss, } \\
\text { serum creatinine, } \\
\text { acute rejection } \\
\text { during study } \\
\text { period. }\end{array}$ & 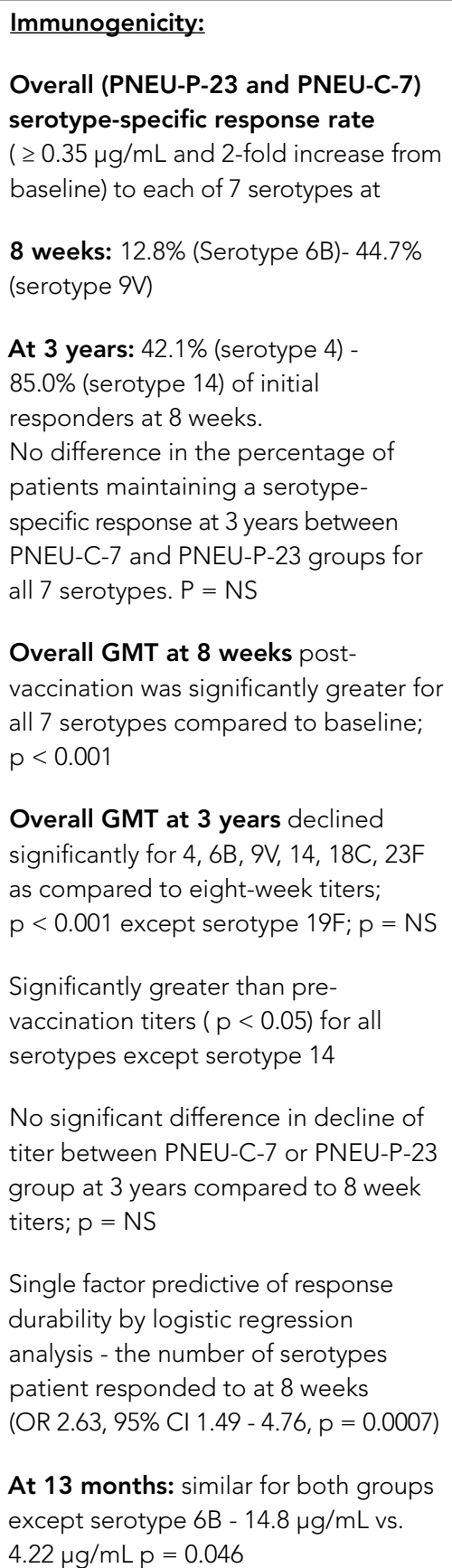 & Level I & Good \\
\hline
\end{tabular}




\begin{tabular}{|c|c|c|c|c|c|c|}
\hline \multicolumn{7}{|c|}{ Evidence for Immunogenicity } \\
\hline \multicolumn{5}{|c|}{ STUDY DETAILS } & \multicolumn{2}{|c|}{ SUMMARY } \\
\hline Study & Vaccine & Study Design & Participants & $\begin{array}{l}\text { Summary of Key Findings Using Text } \\
\text { or Data }\end{array}$ & $\begin{array}{l}\text { Level of } \\
\text { Evidence }\end{array}$ & Quality \\
\hline $\begin{array}{l}\text { Tobudic et al. } \\
\text { (22) }\end{array}$ & $\begin{array}{l}\text { PNEU-C-7 } \\
\text { PNEU-P-23 }\end{array}$ & $\begin{array}{l}\text { Single center } \\
\text { randomized, single } \\
\text { blind, controlled } \\
\text { trial }\end{array}$ & $\begin{array}{l}\mathrm{N}=80 \text { (renal } \\
\text { transplant } \\
\text { recipients) } \\
9 \text { withdrew } \\
9 \text { lost to } \\
\text { follow-up } \\
62 \text { analyzed }\end{array}$ & $\begin{array}{l}\text { Immunogenicity } \\
\text { Response Rate (GMT } 8 \text { weeks post } \\
\text { dose of PNEU-C-7 vs. PNEU-P-23) all } \\
\text { had significant rise as compared to } \\
\text { baseline except serotypes 6B and 19F } \\
\text { in PNEU-P-23. } \\
\text { Response Rate- one year post initial } \\
\text { vaccination: (GMT) declined in for all } \\
\text { serotypes in both vaccines } \\
\text { Response Rate- } 8 \text { weeks post booster } \\
\text { with PNEU-P-23 (GMT) } \\
\text { Serotypes (4,6B,14,18C,23F) had better } \\
\text { responses than in recipients of one } \\
\text { dose PNEU-P-23 } \\
\text { Vaccine response } \geq 2 \text {-fold rise in } \\
\text { antibody concentration and an } \\
\text { absolute value of }>1 \text { ug/mL. } \\
\text { - A response to }>1 \text { serotype after } \\
\text { one vaccination: } \\
77.1 \% \text { PNEU-C-7 } \\
\text { 93.1\% PNEU-P-23 ( } p=0.046 \text { ) } \\
\text { - A response to }>1 \text { serotype after } \\
\text { boost with PNEU-P-23: } \\
87.5 \% \text { PNEU-C-7/PNEU-P-23 } \\
87.1 \% \text { PNEU-P-23/PNEU-P-23 } \\
\text { (not significant) } \\
\text { - Median number of serotypes } \\
\text { with response: } \\
3.5 \text { in PNEU-C-7/PNEU-P-23 } \\
5 \text { in PNEU-P-23 }\end{array}$ & Level 1 & Good \\
\hline
\end{tabular}




\begin{tabular}{|c|c|c|c|c|c|c|}
\hline \multicolumn{7}{|c|}{ Evidence for Immunogenicity } \\
\hline \multicolumn{5}{|c|}{ STUDY DETAILS } & \multicolumn{2}{|c|}{ SUMMARY } \\
\hline Study & Vaccine & Study Design & Participants & $\begin{array}{l}\text { Summary of Key Findings Using Text } \\
\text { or Data }\end{array}$ & $\begin{array}{l}\text { Level of } \\
\text { Evidence }\end{array}$ & Quality \\
\hline $\begin{array}{l}\text { Cordonnier } \\
2009 \text { (23) }\end{array}$ & $\begin{array}{l}\text { PNEU-C-7 } \\
\text { PNEU-P-23 } \\
\text { Schedule: } \\
3 \text { doses of } \\
\text { PNEU-C-7 } \\
\text { given } 1 \\
\text { month apart } \\
\text { at: } \\
3 \text { (early) or } \\
9 \text { (late) months } \\
\text { post- } \\
\text { transplant } \\
\text { PNEU-P-23 at } \\
12 \text { (early) or } \\
18 \text { (late) } \\
\text { months post } \\
\text { transplant }\end{array}$ & $\begin{array}{l}\text { Multicenter, } \\
\text { randomized, } \\
\text { non-inferiority } \\
\text { study. } \\
\text { Non inferiority } \\
\text { margin = -20\% } \\
\text { Length of } \\
\text { follow-up: } \\
24 \text { months } \\
\text { Response = titer at } \\
\text { least } 0.15 \text { mg/L } \\
1 \text { month after } \\
3 \text { rd PNEU-C-7 }\end{array}$ & $\begin{array}{l}\mathrm{N}=158 \\
\text { (Allogeneic } \\
\text { HSCT) } \\
\text { Early group = } 75 \\
\text { Late group = } 83 \\
\text { Analyzed after } \\
\text { 3rd dose of }_{\text {re }} \\
\text { PNEU-C-7: } 57 \\
\text { (early) } 57 \text { (late). } \\
\text { Baseline: } \\
\text { Similar } \\
\text { Both groups } \\
\text { were balanced } \\
\text { with respect to } \\
\text { underlying } \\
\text { disease, status of } \\
\text { HSCT, source of } \\
\text { stem cells, Donor } \\
\text { age, sex and } \\
\text { type, prior } \\
\text { vaccination of } \\
\text { donor, acute and } \\
\text { chronic GVHD, } \\
\text { and time from } \\
\text { HSCT to first } \\
\text { dose of } \\
\text { PNEU-C-7. } \\
\text { The } 2 \text { groups } \\
\text { differed } \\
\text { significantly in } \\
\text { the \% of patients } \\
\text { with antibody } \\
\text { titer } \geq 0.15 \mu g / m L \\
\text { prior to PNEU-C-7 } \\
\text { vaccination. }\end{array}$ & 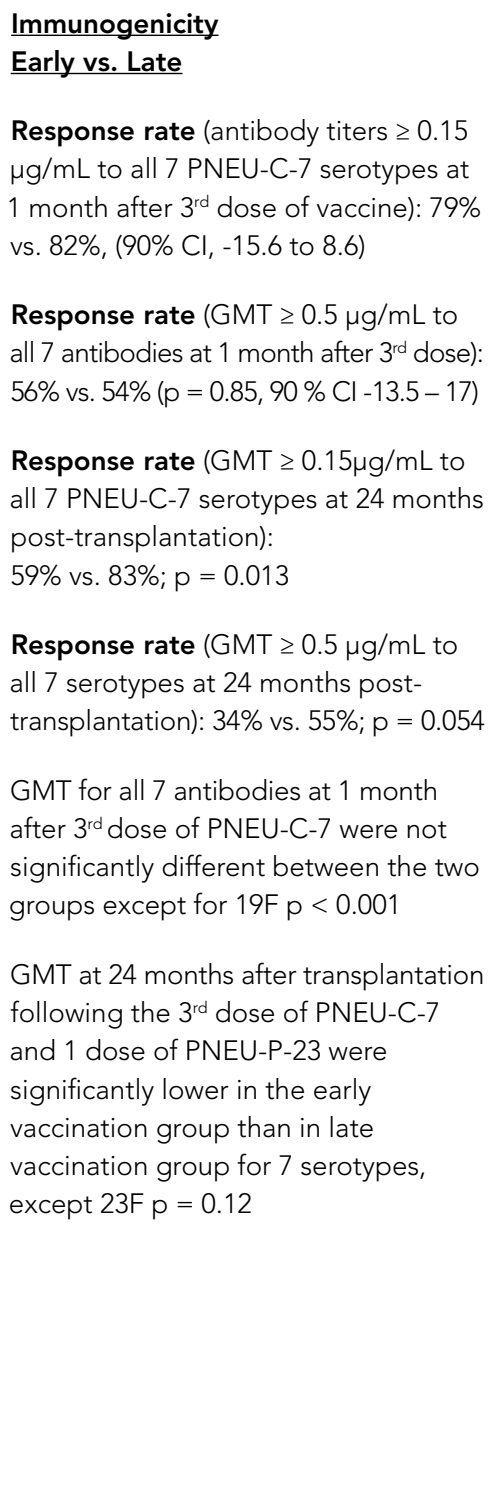 & Level I & Good \\
\hline
\end{tabular}




\begin{tabular}{|c|c|c|c|c|c|c|}
\hline \multicolumn{7}{|c|}{ Evidence for Immunogenicity } \\
\hline \multicolumn{5}{|c|}{ STUDY DETAILS } & \multicolumn{2}{|c|}{ SUMMARY } \\
\hline Study & Vaccine & Study Design & Participants & $\begin{array}{l}\text { Summary of Key Findings Using Text } \\
\text { or Data }\end{array}$ & $\begin{array}{l}\text { Level of } \\
\text { Evidence }\end{array}$ & Quality \\
\hline $\begin{array}{l}\text { Molrine, } 2003 \\
\text { (24) }\end{array}$ & $\begin{array}{l}\text { PNEU-C-7 } \\
\text { Single dose } \\
\text { IM } \\
\text { Schedule } \\
\text { Donors and } \\
\text { recipients } \\
\text { randomized } \\
\text { to PNEU-C-7 } \\
\text { vs. nothing } \\
10 \text { days } \\
\text { pre-HSCT } \\
\text { All HSCT } \\
\text { recipients: } \\
\text { PNEU-C-7 } \\
\text { at 3,6, } \\
\text { 12 months } \\
\text { post-HSCT } \\
\text { Serotypes } \\
\text { tested: } 4,6 B \text {, } \\
9 V, 14,18 C \text {, } \\
\text { 19F, 23F } \\
\text { Non T-cell } \\
\text { depleted } \\
\text { allogeneic } \\
\text { HSCT } \\
\text { Donors who } \\
\text { had received } \\
\text { PNEU-P-23 in } \\
\text { past } 6 \text { years } \\
\text { were excluded }\end{array}$ & $\begin{array}{l}\text { Randomized- } \\
\text { controlled trial } \\
\text { Length of follow } \\
\text { up: } 13 \text { months } \\
\text { *comparison of } \\
\text { GMT made with } \\
\text { patients in another } \\
\text { study with similar } \\
\text { baseline clinical } \\
\text { characteristics, who } \\
\text { received PNEU-P- } \\
23 \text { at } 12 \text { months } \\
\text { Randomization } \\
\text { stratified by age } \\
\text { Subjects } \geq 2 \text { years }\end{array}$ & $\begin{array}{l}96 \text { pairs } \\
\text { randomized - } \\
\text { Allo HSCT } \\
\text { Evaluable } \\
\text { immunized } \\
\text { donors = } 30 \\
\text { Evaluable } \\
\text { unimmunized } \\
\text { donors = } 35 \\
\text { Non-evaluable = } \\
31 \\
\text { Baseline: similar } \\
\text { in both groups } \\
\text { for recipient age, } \\
\text { donor age, race, } \\
\text { sex, diagnosis, } \\
\text { total body } \\
\text { irradiation, } \\
\text { presence of } \\
\text { GVHD, and IVIG } \\
\text { after HSCT. } \\
\text { *Donors } \\
\text { immunized with } \\
\text { a single dose of } \\
\text { PNEU-C-7 had a } \\
\text { significantly } \\
\text { higher GMT to } \\
\text { all } 7 \text { vaccine } \\
\text { serotypes } \\
\text { compared to } \\
\text { unimmunized } \\
\text { donors. }\end{array}$ & 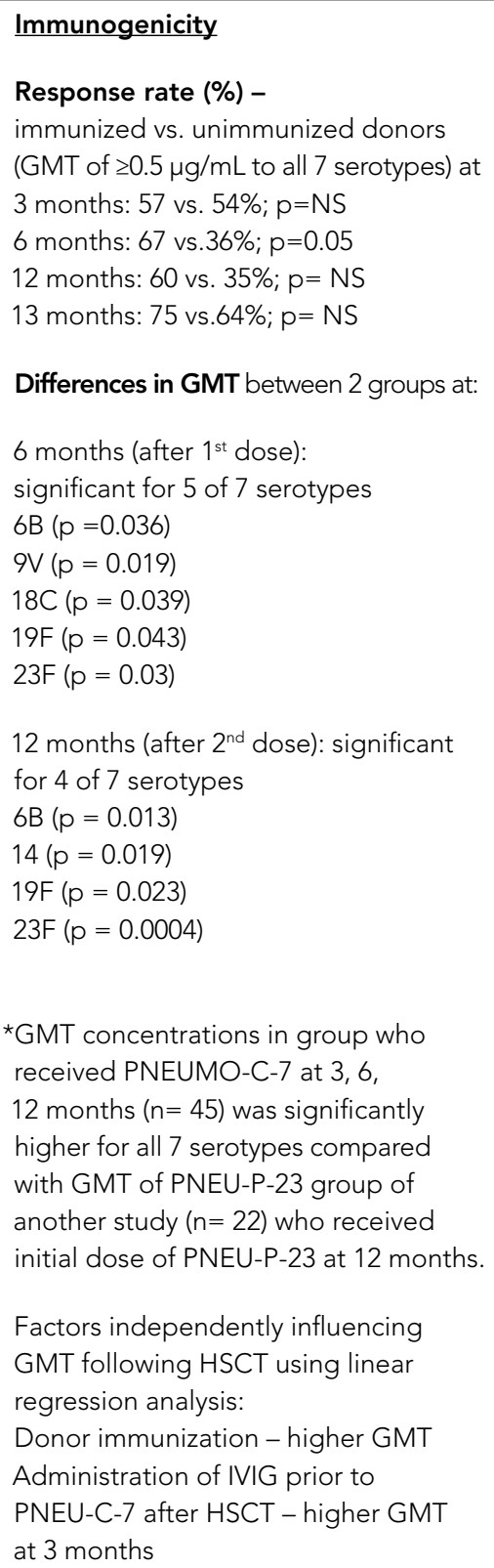 & Level I & Fair \\
\hline
\end{tabular}




\begin{tabular}{|c|c|c|c|c|c|c|}
\hline \multicolumn{7}{|c|}{ Evidence for Immunogenicity } \\
\hline \multicolumn{5}{|c|}{ STUDY DETAILS } & \multicolumn{2}{|c|}{ SUMMARY } \\
\hline Study & Vaccine & Study Design & Participants & $\begin{array}{l}\text { Summary of Key Findings Using Text } \\
\text { or Data }\end{array}$ & $\begin{array}{l}\text { Level of } \\
\text { Evidence }\end{array}$ & Quality \\
\hline $\begin{array}{l}\text { Kumar, } 2007 \\
\text { (25) }\end{array}$ & $\begin{array}{l}\text { PNEU-P-23 } \\
\text { PNEU-C-7 } \\
\text { Dose: } 0.5 \mathrm{~mL} \\
\text { Donors - } \\
\text { recipients } \\
\text { pairs } \\
\text { Donors: } \\
\text { 1 dose of } \\
\text { either } \\
\text { vaccine } \\
\geq 2 \text { weeks } \\
\text { before } \\
\text { harvesting } \\
\text { Recipient: } \\
1 \text { dose of } \\
\text { either } \\
\text { vaccine 6 } \\
\text { months after } \\
\text { HSCT. } \\
\text { Route: IM } \\
\text { Serotypes } \\
\text { tested: } 4,6 B \text {, } \\
\text { 14, 18C, 19F, } \\
23 F .\end{array}$ & $\begin{array}{l}\begin{array}{l}\text { Randomized, } \\
\text { double-blind, } \\
\text { controlled trial. }\end{array} \\
\text { Pairs randomized } \\
\text { Length of follow-up: } \\
12 \text { months post } \\
\text { HSCT. } \\
\text { Response: 2-fold } \\
\text { increase in GMT } \\
\text { and absolute titer } \geq \\
0.35 \mu / \mathrm{mL}\end{array}$ & $\begin{array}{l}\mathrm{N}=64 \text { donor- } \\
\text { recipient pairs } \\
\text { (Allo HSCT) } \\
\text { PNEU-C-7 } \\
\text { pairs = } 32 \\
\text { PNEU-P-23 } \\
\text { pairs = } 32 \\
\text { Baseline: } \\
\text { Similar for } \\
\text { donors and } \\
\text { recipients }\end{array}$ & 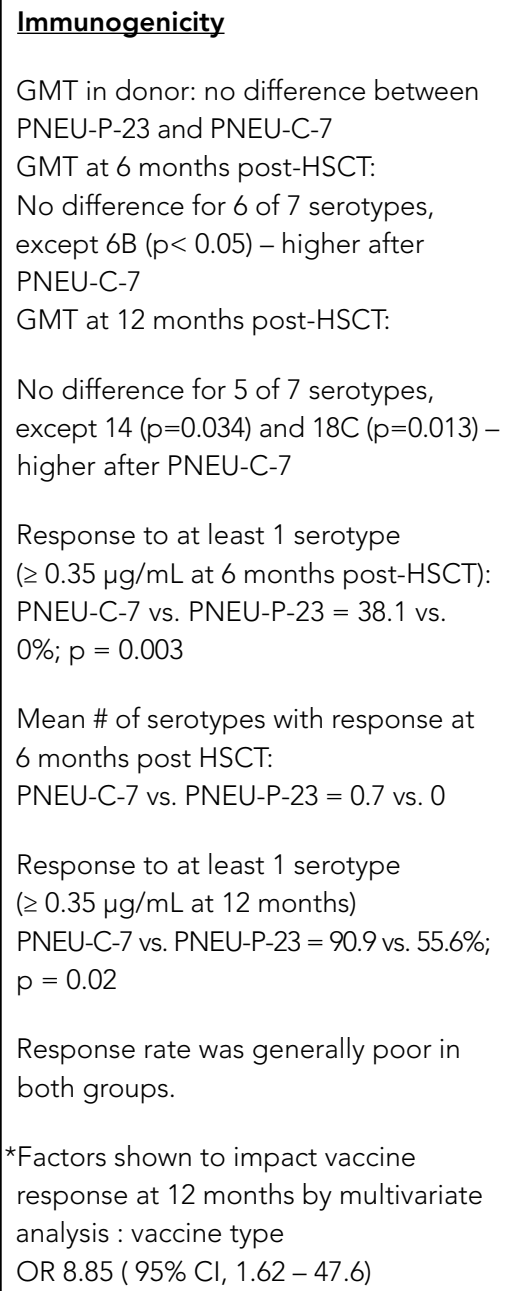 & Level I & Good \\
\hline
\end{tabular}




\begin{tabular}{|c|c|c|c|c|c|c|}
\hline \multicolumn{7}{|c|}{ Evidence for Immunogenicity } \\
\hline \multicolumn{5}{|c|}{ STUDY DETAILS } & \multicolumn{2}{|c|}{ SUMMARY } \\
\hline Study & Vaccine & Study Design & Participants & $\begin{array}{l}\text { Summary of Key Findings Using Text } \\
\text { or Data }\end{array}$ & $\begin{array}{l}\text { Level of } \\
\text { Evidence }\end{array}$ & Quality \\
\hline $\begin{array}{l}\text { Feikin, } 2002 \\
\text { (26) }\end{array}$ & $\begin{array}{l}\text { Combination } \\
\text { of PNEU-C-7, } \\
\text { PNEU-P-23, } \\
\text { or placebo } \\
\text { PNEU-C-7/ } \\
\text { PNEU-C-7 } \\
\text { PNEU-C-7/ } \\
\text { PNEU-P-23 } \\
\text { Placebo/ } \\
\text { PNEU-P-23 } \\
\text { Placebo/ } \\
\text { Placebo } \\
\text { Route: } \\
\text { Intramuscular } \\
\text { deltoid } \\
\text { injection } \\
\text { Schedule: } \\
0,8 \text { weeks. }\end{array}$ & $\begin{array}{l}\text { Randomized } \\
\text { controlled trial. } \\
\text { Length of follow } \\
\text { up: } 24 \text { weeks } \\
\text { Serotypes tested: } \\
4,6 \mathrm{~B}, 9 \mathrm{~V}, 14,23 \mathrm{~F} \\
\text { GMC (lgG) } \\
\text { GMT (OPA) }\end{array}$ & $\begin{array}{l}\mathrm{N}=90 \\
\mathrm{~N}=67 \\
\text { (completed } \\
\text { study) } \\
\text { HIV-infected } \\
\text { adults with } \geq 200 \\
\mathrm{CD} 4 \text { cells/ } \mu \text { l } \\
\text { received } 2 \text {-dose } \\
\text { combinations of } \\
\text { vaccines }\end{array}$ & 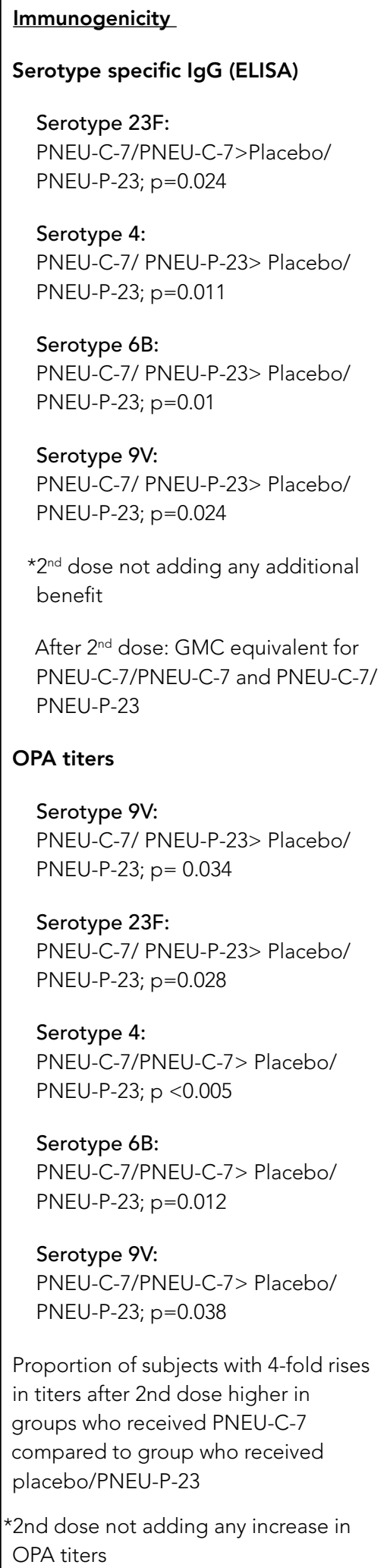 & Level I & Good \\
\hline
\end{tabular}




\begin{tabular}{|c|c|c|c|c|c|c|}
\hline \multicolumn{7}{|c|}{ Evidence for Immunogenicity } \\
\hline \multicolumn{5}{|c|}{ STUDY DETAILS } & \multicolumn{2}{|c|}{ SUMMARY } \\
\hline Study & Vaccine & Study Design & Participants & $\begin{array}{l}\text { Summary of Key Findings Using Text } \\
\text { or Data }\end{array}$ & $\begin{array}{l}\text { Level of } \\
\text { Evidence }\end{array}$ & Quality \\
\hline $\begin{array}{l}\text { Penaranda } \\
2010 \text { (27) }\end{array}$ & $\begin{array}{l}\text { PNEU-C-7 } \\
\text { PNEU-P-23 } \\
\text { Schedule } \\
\text { Group 1: } \\
\text { Single dose } \\
\text { PNEU-C-7 at } \\
0 \text { weeks } \\
\text { followed by } \\
\text { single dose } \\
\text { PNEU-P-23 at } \\
4 \text { weeks. } \\
\text { Group 2: } \\
\text { PNEU-P-23 at } \\
\text { 0 week. }\end{array}$ & $\begin{array}{l}\text { Randomized, } \\
\text { open-label } \\
\text { multicenter study } \\
\text { Previously } \\
\text { unimmunized } \\
\text { adults with HIV and } \\
\text { CD4 count } \\
\text { between } 200-500 \\
\text { cells/ } \mu \text { l and HIV } \\
\text { viral load }<5 \text { log } \\
\text { copies/mL } \\
\text { Length of } \\
\text { follow-up: } 8 \text { weeks. }\end{array}$ & $\begin{array}{l}\mathrm{N}=220 \text { (110 each } \\
\text { group) } \\
\text { Randomized to: } \\
\text { PNEU-C-7/ } \\
\text { PNEU-P-23 } \\
4 \text { weeks later } \\
\text { OR } \\
\text { PNEU-P-23 alone } \\
\text { Patient } \\
\text { characteristics: } \\
\text { Similar at } \\
\text { baseline except } \\
\text { for proportion of } \\
\text { patients taking } \\
\text { HAART: } \\
\text { 98\% in group } 1 \text { vs. } \\
\text { 91\% in group } 2\end{array}$ & $\begin{array}{l}\text { Primary end points } \\
\text { 1) Specific lgG } \geq 2 \text { fold } \\
\text { 2) Specific lgG increase } 2 \text {-fold AND } \\
\text { reaching } 1 \mu \mathrm{g} / \mathrm{mL} \\
\text { Percentage of responders at } 8 \text { weeks } \\
\text { using criteria } 1 \text { and } 2 \text { : } \\
\text { No difference between } 2 \text { groups } \\
\text { except for serotype } 23 \mathrm{~F}: \\
26 \% \text { (combined) vs. } 14 \% \text { responders } \\
\text { (alone) } \\
\text { OR }=2.2 ; 95 \% \mathrm{Cl} 1.07-4.56 \\
\text { No difference in avidity }\end{array}$ & Level I & Good \\
\hline $\begin{array}{l}\text { Crum- } \\
\text { Cianflone, } \\
2010 \text { (28) }\end{array}$ & $\begin{array}{l}\text { Revaccination } \\
\text { using } \\
\text { PNEU-C-7 or } \\
\text { PNEU-P-23 } \\
\text { Single } 3 \text { to } 8 \\
\text { years after } \\
\text { previous } \\
\text { PNEU-P-23 }\end{array}$ & $\begin{array}{l}\text { Randomized } \\
\text { controlled trial. } \\
\text { HIV infected } \\
\text { randomized 2:1 } \\
\text { (PNEU-C-7: } \\
\text { PNEU-P-23) } \\
\text { HIV uninfected: } \\
1 \text { dose PNEU-C-7 } \\
\text { Patients: } \\
\text { 18-60 years } \\
\text { Length of } \\
\text { follow-up: } 180 \text { days. } \\
\text { Duration of study: } \\
\text { Feb 2006- } \\
\text { September } 2008\end{array}$ & $\begin{array}{l}\mathrm{N}=131 \\
\text { (PNEU-C-7) } \\
\mathrm{N}=73 \\
\text { (PNEU-P-23) } \\
\text { HIV-infected } \\
\text { adults vaccinated } \\
\text { with PNEU-P-23 } \\
\text { 3-8 years earlier } \\
\mathrm{N}=25 \text { in } \\
\text { HIV-uninfected } \\
\text { arm not } \\
\text { vaccinated a } \\
\text { priori } \\
\text { Baseline: similar } \\
\text { (median CD4 } \\
\text { count }>500 \text { cells/ } \\
\text { mm3) except for } \\
\text { HAART (\%) = } \\
\text { 84.7, 56. }\end{array}$ & $\begin{array}{l}\text { Primary end point: } \\
\text { Proportion of subjects with positive } \\
\text { antibody response to at least } 2 \text { of } 4 \\
(4,9 V, 14,19 F) \text { serotypes at day } 60 . \\
\text { Positive response: } \geq 2 \text { fold response } \\
\text { in IgG level } \\
\text { Proportion with response to } 2 \text { of } 4 \\
\text { serotypes at } 60 \text { days: } \\
\text { PNEU-C-7 = 57\% vs. PNEU-P-23 = 36\%; } \\
\text { P=0.004 (HIV uninfected = 88\%) } \\
\text { Mean changes in lgG concentration } \\
\text { from baseline to } \\
\text { Day 60: PNEU-C-7 > PNEU-P-23 for } \\
\text { serotypes 4, 9V, 19F (p < 0.05), not for } \\
\text { serotype 14. } \\
\text { Day 180: PNEU-C-7 = PNEU-P-23 } \\
\text { HIV-uninfected group: greater } \\
\text { response in frequency and magnitude } \\
\text { compared to HIV-infected group. } \\
\text { Adjusted OR for response to } 2 \text { of } 4 \\
\text { serotypes } \\
\text { HIV infected: PNEU-C-7 vs. PNEU-P-23: } \\
\text { OR = 2.6 (1.4-5.0) } \\
\text { PNEU-C-7: HIV infected vs. uninfected: } \\
\text { OR = 0.2 (0.1-0.7) }\end{array}$ & Level I & Good \\
\hline
\end{tabular}




\begin{tabular}{|c|c|c|c|c|c|c|}
\hline \multicolumn{7}{|c|}{ Evidence for Immunogenicity } \\
\hline \multicolumn{5}{|c|}{ STUDY DETAILS } & \multicolumn{2}{|c|}{ SUMMARY } \\
\hline Study & Vaccine & Study Design & Participants & $\begin{array}{l}\text { Summary of Key Findings Using Text } \\
\text { or Data }\end{array}$ & $\begin{array}{l}\text { Level of } \\
\text { Evidence }\end{array}$ & Quality \\
\hline $\begin{array}{l}\text { Lesprit, } 2007 \\
\text { (29) }\end{array}$ & $\begin{array}{l}\text { PNEU-C-7/ } \\
\text { PNEU-P-23 at } \\
4 \text { weeks later } \\
\text { OR } \\
\text { PNEU-P-23 at } \\
4 \text { weeks } \\
\text { Dose -n/a } \\
\text { Route - n/a }\end{array}$ & $\begin{array}{l}\text { Randomized } \\
\text { controlled } \\
\text { trial - stratified on } \\
\text { CD4 at baseline } \\
\text { and prior ARV } \\
\text { Length of } \\
\text { follow-up: } \\
24 \text { weeks } \\
\text { Inclusion: } \\
\text { HIV1 with } \\
\text { CD4: } 200-500 \\
\text { VL: <50,000 copies/ } \\
\text { mL; ARV naïve or } \\
\text { stable regimen x at } \\
\text { least } 3 \text { months; } \\
\text { no pneumococcal } \\
\text { infection in previous } \\
5 \text { years } \\
\text { Patients screened } \\
\text { between } \\
\text { December } 2002 \\
\text { and December } \\
2003\end{array}$ & $\begin{array}{l}\mathrm{N}=212 \\
\text { (HIV-infected } \\
\text { patients) } \\
\text { Randomized to: } \\
\text { PNEU-C-7/ } \\
\text { PNEU-P-23 (106) } \\
\text { PNEU-P-23 alone } \\
\text { (106) } \\
\text { Baseline: } \\
\text { No difference } \\
\text { in baseline } \\
\text { characteristics } \\
\text { between } 2 \text { groups }\end{array}$ & $\begin{array}{l}\text { Immunogenicity Outcomes } \\
\text { a) } 2 \text {-fold increase in serotype-specific } \\
\text { IgG levels } \\
\text { b) } 2 \text {-fold increase AND level of at } \\
\text { least } 1 \mathrm{mg} / \mathrm{L} \\
\text { Baseline: IgG titers not different in } \\
\text { both groups } \\
\text { At week } 8 \text { ( } 4 \text { weeks after PNEU-P-23 in } \\
\text { both groups): IgG titers same for both } \\
\text { groups except for } 18 \mathrm{C} \text { and } 23 \mathrm{~F} \text { (higher } \\
\text { with combined schedule) } \\
\text { At week } 24 \text { : IgG titers same for both } \\
\text { groups except for } 18 C, 23 F, 14 \text {, and } 19 F \text {. } \\
\text { Proportion of subjects who met } \\
\text { criteria b above: } \\
\text { No difference between groups at } 8 \text { weeks, } \\
\text { except for response to } 5 \text { of } 7 \text { serotypes } \\
\text { (59\% of combined vs. } 40 \% \text { of PNEU-P-23, } \\
\text { p= } 0.005 \text { ) and same for levels at week } 24 \text {, } \\
\text { except for response to } 5 \text { of } 7 \text { serotypes } \\
\text { (30\% of combined vs. } 10 \% \text { of PNEU-P-23, } \\
\text { p=0.003). }\end{array}$ & Level I & Good \\
\hline
\end{tabular}




\begin{tabular}{|c|c|c|c|c|c|c|}
\hline \multicolumn{7}{|c|}{ Evidence for Immunogenicity } \\
\hline \multicolumn{5}{|c|}{ STUDY DETAILS } & \multicolumn{2}{|c|}{ SUMMARY } \\
\hline Study & Vaccine & Study Design & Participants & $\begin{array}{l}\text { Summary of Key Findings Using Text } \\
\text { or Data }\end{array}$ & $\begin{array}{l}\text { Level of } \\
\text { Evidence }\end{array}$ & Quality \\
\hline $\begin{array}{l}\text { Frenck, } 2012 \\
\text { (30) }\end{array}$ & $\begin{array}{l}\text { PNEU-C-13/ } \\
\text { TIV - placebo } \\
\text { (1 month } \\
\text { later) } \\
\text { vs. Placebo/ } \\
\text { TIV - PNEU- } \\
\text { C-13 } 1 \text { month } \\
\text { later } \\
0.5 \mathrm{~mL} \mathrm{IM}\end{array}$ & $\begin{array}{l}\text { Randomized } \\
\text { controlled trial } \\
\text { Population: Healthy } \\
50-59 \text { years of age. } \\
\text { No previous } \\
\text { pneumococcal } \\
\text { vaccination }\end{array}$ & $\begin{array}{l}\text { Multicentric - U.S. } \\
\mathrm{N}=1158 \\
\text { enrolled } \\
\mathrm{N}=1116 \\
\text { randomized } \\
\mathrm{N} 1=554 \\
\text { (PNEU-C-13/TIV) } \\
\mathrm{N} 2=562 \text { (TIV } \\
\text { then PNEU-C-13) }\end{array}$ & $\begin{array}{l}\text { PNEU-C-13 IgG serotype specific } \\
\text { response (ELISA) } 1 \text { month after } \\
\text { pneumococcal vaccination } \\
\text { OPA: serotype specific response } \\
\text { 1. GMCs between } 1.15 \text { (serotype 3) } \\
\text { and } 16.80 \text { (19A) } \mu \mathrm{g} / \mathrm{mL} \text { in } \\
\text { concomitant group and between } \\
\text { 1.46 (3) and } 18.84 \text { ( } 19 \mathrm{~A} \text { ) } \mu \mathrm{g} / \mathrm{mL} \text { in } \\
\text { PNEU-C-13 group } \\
\text { 2. OPA GMTs between } 61 \text { (serotype } 3 \text { ) } \\
\text { and } 2421 \text { (6B) in concomitant } \\
\text { group and between } 78 \text { (3) and } \\
\text { 3215 (6B) in PNEU-C-13 group } \\
\text { 3. Response to TIV: similar in both } \\
\text { groups } \\
\text { 4. Response to PNEU-C-13: } \\
\text { a) GMCs tended to be lower } \\
\text { in the concomitant } \\
\text { administration group with } \\
\text { ratios from } 0.69 \text { to } 0.89 \text { - } \\
\text { none reached the inferiority } \\
\text { criterion; } \\
\text { b) OPA GMTs also tended to be } \\
\text { lower in the concomitant } \\
\text { group with ratios ranging } \\
\text { from } 0.5 \text { to } 0.8 \text { - serotypes } 1 \text {, } \\
5,7 F, 9 V \text {, and } 19 F \text { met the } \\
\text { inferiority criterion (lower } \\
\text { bound of } 95 \% \mathrm{Cl}<0.5 \text { ) }\end{array}$ & Level I & Good \\
\hline $\begin{array}{l}\text { Schwarz, } 2011 \\
\text { (31) }\end{array}$ & $\begin{array}{l}\text { PNEU-C-13/ } \\
\text { TIV - placebo } \\
\text { (1 month later) } \\
\text { vs. } \\
\text { Placebo/ TIV- } \\
\text { PNEU-C-13 } \\
1 \text { month later } \\
0.5 \text { mL IM }\end{array}$ & $\begin{array}{l}\text { Randomized } \\
\text { controlled trial } \\
\text { All PNEU-C-13 } \\
\text { serotypes tested } \\
\text { Healthy } 65 \text { years } \\
\text { and over. } \\
\text { No previous } \\
\text { pneumococcal } \\
\text { vaccination } \\
\text { Follow-up until } \\
1 \text { month after } \\
\text { last vaccine } \\
\text { administered }\end{array}$ & $\begin{array}{l}\text { Multicentric - } \\
\text { Europe } \\
\mathrm{N}=1190 \\
\text { participants } \\
\text { enrolled; } 1160 \\
\text { randomized - } \\
580 \text { in each } \\
\text { group } \\
1096 \text { evaluable }\end{array}$ & $\begin{array}{l}\text { IgG specific GMCs in each arm - ratio } \\
\text { of GMCs } \\
\text { 1. GMCs between } 1.08 \text { (serotype 3) } \\
\text { and } 11.98 \text { (19A) } \mu \mathrm{g} / \mathrm{mL} \text { in } \\
\text { concomitant group and between } \\
1.15 \text { (3) and } 17.10(19 \mathrm{~A}) \mu \mathrm{g} / \mathrm{mL} \text { in } \\
\text { PNEU-C-13 group } \\
\text { 2. Response to TIV: similar in both } \\
\text { groups } \\
\text { 3. Response to PNEU-C-13: } \\
\text { GMCs tended to be lower in the } \\
\text { concomitant administration group } \\
\text { with ratios from } 0.65 \text { to } 0.97 \text { - only } \\
\text { serotype } 19 \mathrm{~F} \text { was below the } \\
\text { non-inferiority value (lower bound } \\
\mathrm{Cl}<0.5 \text { ). }\end{array}$ & Level I & Good \\
\hline
\end{tabular}




\begin{tabular}{|c|c|c|c|c|c|c|}
\hline \multicolumn{7}{|c|}{ Evidence for Immunogenicity } \\
\hline \multicolumn{5}{|c|}{ STUDY DETAILS } & \multicolumn{2}{|c|}{ SUMMARY } \\
\hline Study & Vaccine & Study Design & Participants & $\begin{array}{l}\text { Summary of Key Findings Using Text } \\
\text { or Data }\end{array}$ & $\begin{array}{l}\text { Level of } \\
\text { Evidence }\end{array}$ & Quality \\
\hline $\begin{array}{l}\text { Jackson, } 2007 \\
\text { (32) }\end{array}$ & $\begin{array}{l}\text { PNEU-C-7 } \\
\text { PNEU-P-23 } \\
\text { Dose } \\
\text { (PNEU-C-7): } \\
0.1 \mathrm{~mL} \text { or } 0.5 \\
\mathrm{~mL} \text { or } \\
1 \mathrm{~mL} \text { or } \\
2 \mathrm{~mL} \text { or } \\
\text { *PNEU-C-7 } \\
\text { licensed at } \\
0.5 \mathrm{~mL} \text { in } \\
\text { children } \\
\text { Dose } \\
\text { (PNEU-P-23): } \\
0.5 \mathrm{~mL} \text { IM } \\
0.1 \mathrm{~mL} \\
\text { challenge } \\
\text { with } \\
\text { PNEU-P-23 } \\
\text { dose at } \\
1 \text { year }\end{array}$ & $\begin{array}{l}\text { Randomized } \\
\text { controlled trial. } \\
\text { Length of } \\
\text { follow-up: } 1 \text { year } \\
\text { and } 4 \text { weeks. } \\
\text { Serotypes tested: } \\
\text { 4,6B, 9V, 14, 18C, } \\
\text { 19F, 23F. } \\
\text { Population: } \\
\text { Aged } 70-79 \text { years } \\
\text { who had received } \\
\text { PNEU-P-23 on or } \\
\text { after } 65^{\text {th }} \text { birthday, } \\
\text { at least } 5 \text { years } \\
\text { prior }\end{array}$ & $\begin{array}{l}\mathrm{N}=220 \\
\text { Randomized } 4: 1 \\
\text { by group of } 55 \text { to } \\
\text { PNEU-C-7 at } 0.1 \text {, } \\
0.5,1 \text {, and } 2 \mathrm{~mL} \\
\text { vs. PNEU-P-23 } \\
\mathrm{N}=219 \\
\text { (analyzed after } 1^{\text {st }} \\
\text { vaccination) } \\
\mathrm{N}=208 \text { (before } \\
\text { challenge } \\
\text { PNEU-P-23 } \\
\text { vaccine) } \\
\mathrm{N}=203 \\
\text { (analyzed } \\
\text { post-challenge } \\
\text { vaccination) }\end{array}$ & 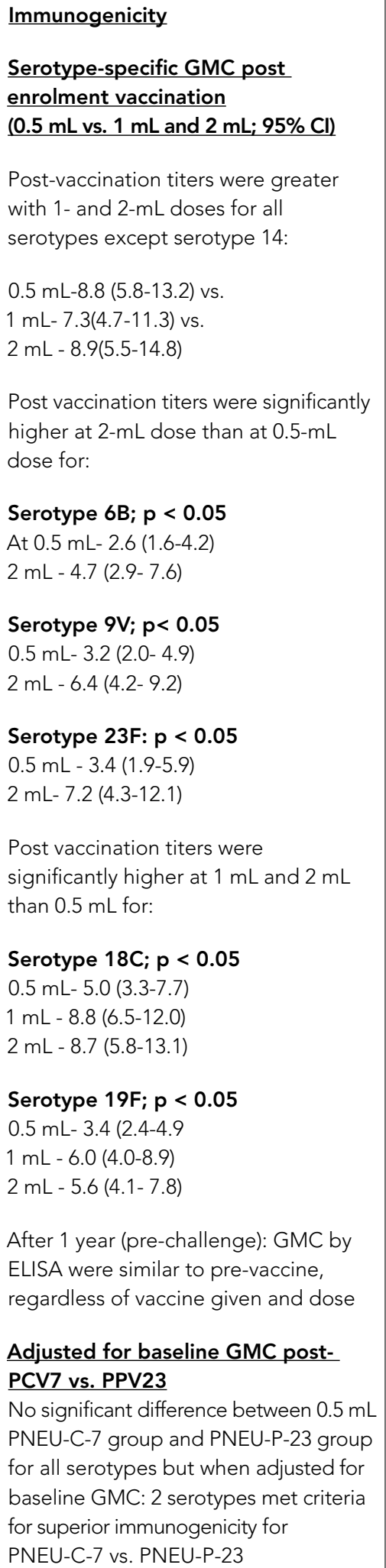 & Level I & Good \\
\hline
\end{tabular}




\begin{tabular}{|c|c|c|c|c|c|c|}
\hline \multicolumn{7}{|c|}{ Evidence for Immunogenicity } \\
\hline \multicolumn{5}{|c|}{ STUDY DETAILS } & \multicolumn{2}{|c|}{ SUMMARY } \\
\hline Study & Vaccine & Study Design & Participants & $\begin{array}{l}\text { Summary of Key Findings Using Text } \\
\text { or Data }\end{array}$ & $\begin{array}{l}\text { Level of } \\
\text { Evidence }\end{array}$ & Quality \\
\hline & & & & 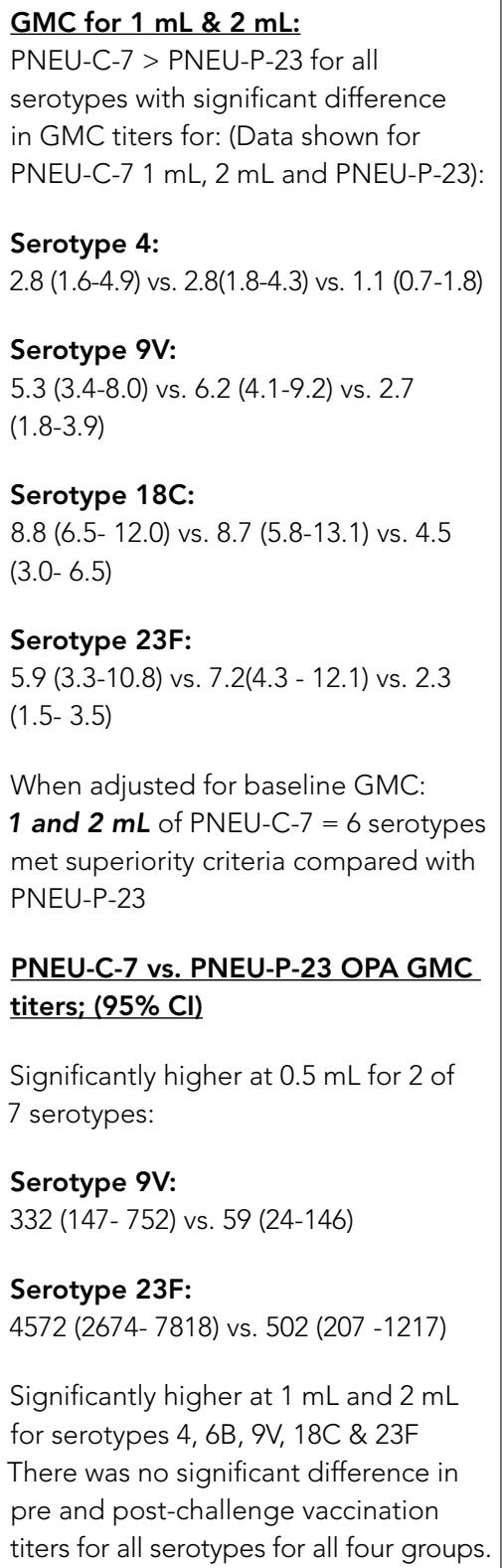 & & \\
\hline
\end{tabular}




\begin{tabular}{|c|c|c|c|c|c|c|}
\hline \multicolumn{7}{|c|}{ Evidence for Immunogenicity } \\
\hline \multicolumn{5}{|c|}{ STUDY DETAILS } & \multicolumn{2}{|c|}{ SUMMARY } \\
\hline Study & Vaccine & Study Design & Participants & $\begin{array}{l}\text { Summary of Key Findings Using Text } \\
\text { or Data }\end{array}$ & $\begin{array}{l}\text { Level of } \\
\text { Evidence }\end{array}$ & Quality \\
\hline $\begin{array}{l}\text { De Roux, } 2008 \\
\text { (33) }\end{array}$ & $\begin{array}{l}\text { PNEU-C-7 } \\
\text { followed by } \\
\text { either } \\
\text { PNEU-C-7 or } \\
\text { PNEU-P-23 } \\
\text { one year later } \\
\text { OR } \\
\text { PNEU-P-23 } \\
\text { followed by } \\
\text { PNEU-C-7 } \\
\text { one year later }\end{array}$ & $\begin{array}{l}\text { Randomized } \\
\text { open-labeled } \\
\text { phase } 2 \text { study } \\
\text { Length of } \\
\text { follow-up: } \\
13 \text { months } \\
\text { Population: } 70 \text { years } \\
\text { and older with NO } \\
\text { previous } \\
\text { pneumococcal } \\
\text { vaccination }\end{array}$ & $\begin{array}{l}\mathrm{N}=219 \\
\text { ambulatory } \\
\text { elderly adults } \geq \\
70 \text { years } \\
\text { PNEU-C-7 } \\
1^{\text {st }} \text { dose }=110 \\
\text { PNEU-P-23 } \\
1^{\text {st }} \text { dose }=109 \\
\text { PNEU-C-7/ } \\
\text { PNEU-C-7 = 43 } \\
\text { PNEU-C-7/ } \\
\text { PNEU-P-23 = 38 } \\
\text { PNEU-P-23/ } \\
\text { PNEU-C-7 = 78 } \\
\text { Baseline: } \\
\text { pre-immunization } \\
\text { antibody levels } \\
\text { were similar } \\
\text { between initial } \\
\text { groups. Mean } \\
\text { age at entry was } \\
75 \text { years. }\end{array}$ & 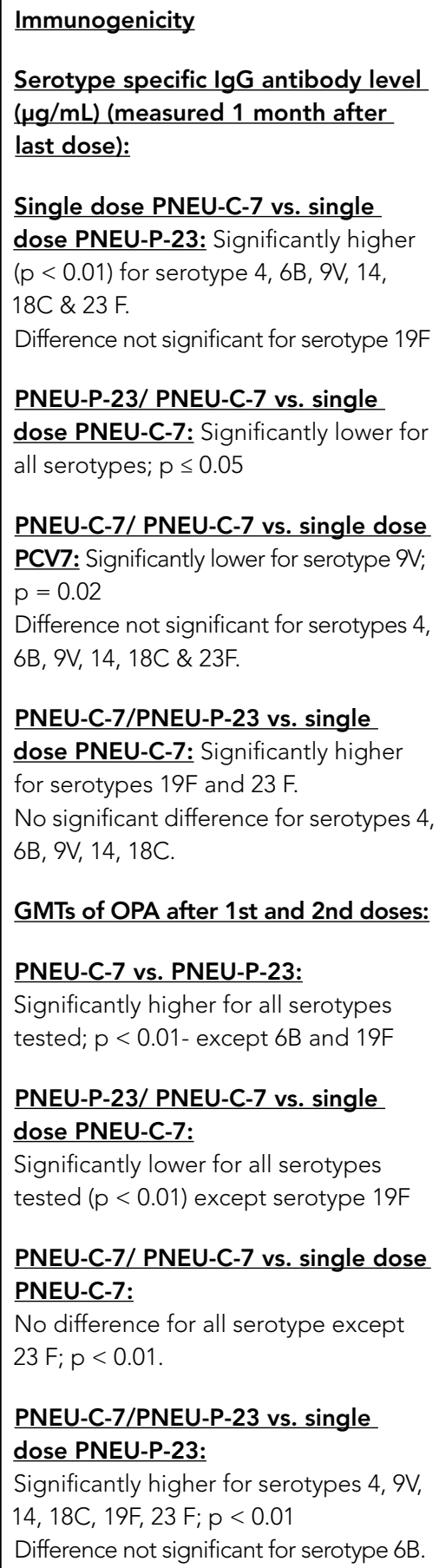 & Level I & Good \\
\hline
\end{tabular}




\begin{tabular}{|c|c|c|c|c|c|c|}
\hline \multicolumn{7}{|c|}{ Evidence for Immunogenicity } \\
\hline \multicolumn{5}{|c|}{ STUDY DETAILS } & \multicolumn{2}{|c|}{ SUMMARY } \\
\hline Study & Vaccine & Study Design & Participants & $\begin{array}{l}\text { Summary of Key Findings Using Text } \\
\text { or Data }\end{array}$ & $\begin{array}{l}\text { Level of } \\
\text { Evidence }\end{array}$ & Quality \\
\hline $\begin{array}{l}\text { Miernyk, } 2009 \\
\text { (34) }\end{array}$ & $\begin{array}{l}\text { PNEU-P-23 } \\
\text { PNEU-C-7 } \\
\text { Dose: } 0.5 \mathrm{~mL} \\
\text { IM } \\
\text { Group 1: } \\
\text { PNEU-P- } 23 \\
\text { Group 2: } \\
\text { PNEU-C-7/ } \\
\text { PNEU-P-23 } \\
\text { 2 months } \\
\text { later } \\
\text { Group 3: } \\
\text { PNEU-C-7/ } \\
\text { PNEU-P-23 } \\
\text { 6 months } \\
\text { later } \\
\text { Serotypes } \\
\text { tested: 1, 4, } \\
\text { 6B, 14, 19F. }\end{array}$ & $\begin{array}{l}\text { Randomized } \\
\text { controlled trial } \\
\text { Population: } \\
\text { Alaskan Natives } \\
\text { aged 55-70 years } \\
\text { Not previously } \\
\text { vaccinated against } \\
\text { pneumo }\end{array}$ & $\begin{array}{l}\text { PNEU-P-23 = } 28 \\
\text { PNEU-C-7/ } \\
\text { PNEU-P-23 } \\
2 \text { months later = } \\
29 \\
\text { PNEU-C-7/ } \\
\text { PNEU-P-23 } \\
6 \text { months later = } \\
29 \\
\text { Baseline: study } \\
\text { groups did not } \\
\text { differ significantly } \\
\text { in age or gender. }\end{array}$ & 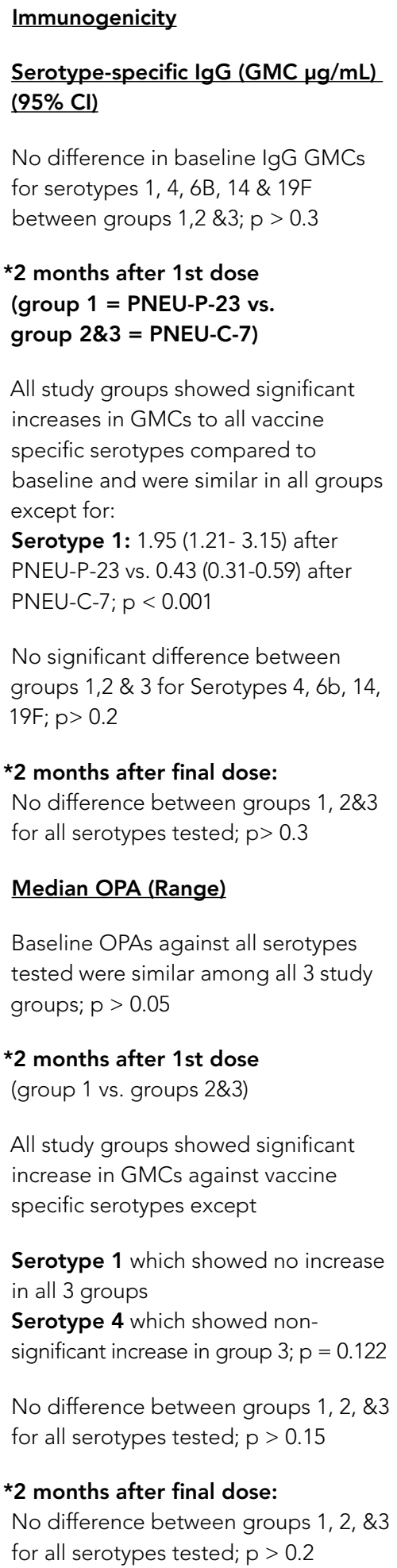 & Level I & Good \\
\hline
\end{tabular}




\begin{tabular}{|c|c|c|c|c|c|c|}
\hline \multicolumn{7}{|c|}{ Evidence for Immunogenicity } \\
\hline \multicolumn{5}{|c|}{ STUDY DETAILS } & \multicolumn{2}{|c|}{ SUMMARY } \\
\hline Study & Vaccine & Study Design & Participants & $\begin{array}{l}\text { Summary of Key Findings Using Text } \\
\text { or Data }\end{array}$ & $\begin{array}{l}\text { Level of } \\
\text { Evidence }\end{array}$ & Quality \\
\hline $\begin{array}{l}\text { Goldblatt, } \\
2009 \text { (35) }\end{array}$ & $\begin{array}{l}\text { PNEU-C-7 } \\
\text { PNEU-P-23 } \\
\text { Group 1: } \\
\text { PNEU-C-7/ } \\
\text { PNEU-C-7 } \\
6 \text { months } \\
\text { later } \\
\text { Group 2: } \\
\text { PNEU-C-7/ } \\
\text { PNEU-P-23 } \\
\text { 6 months } \\
\text { later } \\
\text { Group 3: } \\
\text { PNEU-P-23 } \\
\text { Group 4: } \\
\text { PNEU-C-7 }\end{array}$ & $\begin{array}{l}\text { Randomized } \\
\text { open-labeled } \\
\text { controlled trial } \\
\text { Length of } \\
\text { follow-up: } \\
12 \text { months } \\
\text { lgG titers cut-off: } \\
0.35 \mathrm{ug} / \mathrm{mL}\end{array}$ & $\begin{array}{l}\text { Group } 1=133 \\
\text { Group 2=171 } \\
\text { Group 3=159 } \\
\text { Group 4=136 } \\
\text { Study patients } \\
\text { were 50-80 yrs, } \\
\text { did not receive } \\
\text { either pneumo } \\
\text { vaccine in } 3 \leq \\
5 \text { yrs before } \\
\text { recruitment. } \\
\text { There were } \\
\text { similar numbers } \\
\text { of individuals in } \\
\text { the } 50-59,60-69, \\
70-79 \text { age in } \\
\text { each group. } \\
\text { No baseline } \\
\text { characteristics } \\
\text { provided }\end{array}$ & 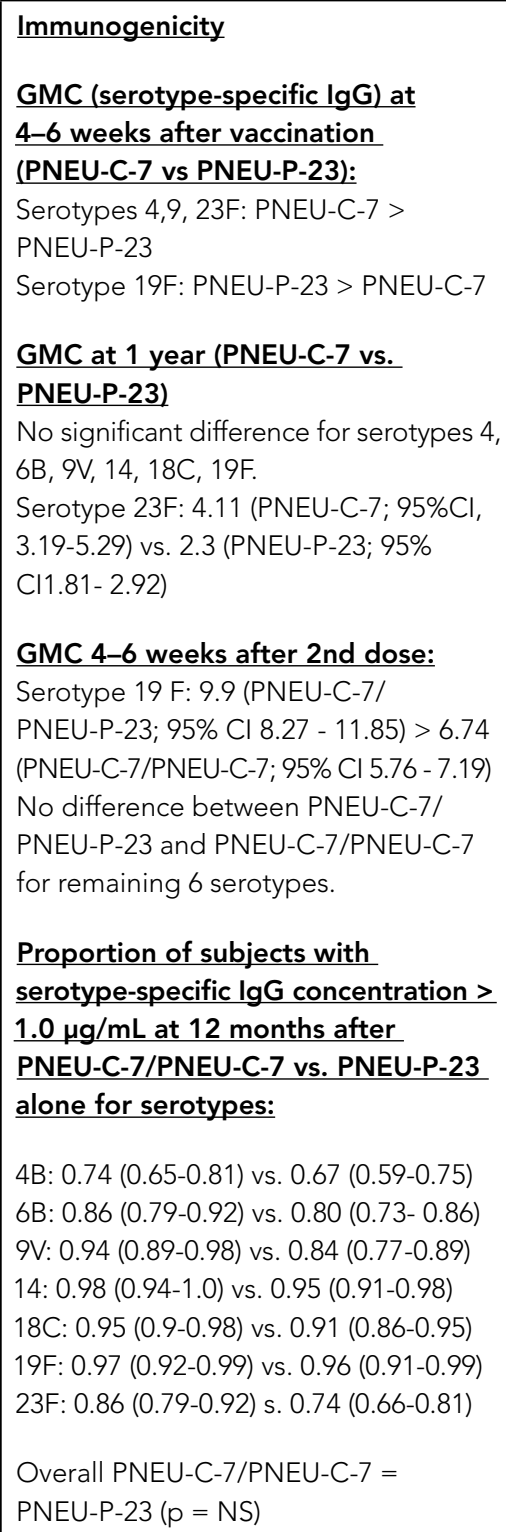 & Level I & Good \\
\hline
\end{tabular}




\begin{tabular}{|c|c|c|c|c|c|c|}
\hline \multicolumn{7}{|c|}{ Evidence for Immunogenicity } \\
\hline \multicolumn{5}{|c|}{ STUDY DETAILS } & \multicolumn{2}{|c|}{ SUMMARY } \\
\hline Study & Vaccine & Study Design & Participants & $\begin{array}{l}\text { Summary of Key Findings Using Text } \\
\text { or Data }\end{array}$ & $\begin{array}{l}\text { Level of } \\
\text { Evidence }\end{array}$ & Quality \\
\hline $\begin{array}{l}\text { Schenkein, } \\
2008 \text { (36) }\end{array}$ & $\begin{array}{l}\text { PNEU-P-23 } \\
0.5 \mathrm{~mL} \times 1 \\
\text { IM } \\
\text { Serotypes } \\
\text { tested: } 4,6 \mathrm{~B}, \\
9 \mathrm{~V}, 14,18 \mathrm{C}, \\
\text { 19F, 23F } \\
\text { tested } 28 \\
\text { days post } \\
\text { vaccine }\end{array}$ & $\begin{array}{l}\text { Randomized } \\
\text { controlled trial } \\
\text { Comparative study } \\
\text { of immune response } \\
\text { in those aged } \\
65 \text { years and above } \\
\text { vs. aged } 45 \text { years } \\
\text { and less }\end{array}$ & $\begin{array}{l}<45 \text { years }=45 \\
\geq 65 \text { years }=58 \\
\text { Older adults } \\
\text { were community } \\
\text { dwelling } \\
\text { individuals taken } \\
\text { from control } \\
\text { group subset of } \\
\text { a previously } \\
\text { reported } \\
\text { randomized, } \\
\text { double-blind, } \\
\text { placebo } \\
\text { controlled trial. } \\
\text { Younger adults } \\
\text { were healthy } \\
\text { volunteers } \\
\text { recruited from } \\
\text { lab research } \\
\text { personnel from } \\
\text { large university } \\
\text { medical center. }\end{array}$ & $\begin{array}{l}\text { Immunogenicity } \\
\text { Serotype-specific IgG GMC: } \\
\text { No difference in GMC between } \\
\text { younger and older age group for } \\
\text { serotypes 4, 6B, } 9 \text { V, 14, 18C \& 23F. } \\
\text { Serotype 19F: 9.14 vs. 5.24; } p=0.001 \\
\text { Serotype specific OPA titers (95\% Cl) } \\
\text { Serotype 4: } 1735 \text { (1074-2804) vs. } \\
\text { 453 (250-821); } p<0.01 \\
\text { Serotype 6B: } 1707(1046-2787) \text { vs. } \\
377 \text { (188-756); } p<0.01 \\
\text { Serotype 9V: } 3957(1921-8151) \text { vs. } \\
\text { 411(203-832); } p<0.001 \\
\text { Serotype 14: } 3715 \text { (1888-7309) vs. } \\
\text { 1250 (717-2179); } p<0.01 \\
\text { Serotype 18C: } 1344 \text { (721-2505) vs. } \\
933 \text { (500-1740); } p=0.09 \\
\text { Serotype 19F: } 1254 \text { (707-2223) vs. } \\
266 \text { (133-532) } p<0.01 \\
\text { Serotype 23F: } 766 \text { (377-1554) vs. } \\
147 \text { (76-285); } p<0.001 \\
\text { Antibody potency (OT/lgG): } \\
\text { Significantly higher for all serotypes in } \\
\text { the younger age group than in the } \\
\text { older age group; } p<0.05 \text { for all serotypes. }\end{array}$ & Level I & Good \\
\hline
\end{tabular}




\begin{tabular}{|c|c|c|c|c|c|c|}
\hline \multicolumn{7}{|c|}{ Evidence for Immunogenicity } \\
\hline \multicolumn{5}{|c|}{ STUDY DETAILS } & \multicolumn{2}{|c|}{ SUMMARY } \\
\hline Study & Vaccine & Study Design & Participants & $\begin{array}{l}\text { Summary of Key Findings Using Text } \\
\text { or Data }\end{array}$ & $\begin{array}{l}\text { Level of } \\
\text { Evidence }\end{array}$ & Quality \\
\hline $\begin{array}{l}\text { Musher, } 2010 \\
\text { (37) }\end{array}$ & $\begin{array}{l}\text { PNEU-P-23 } \\
\text { Placebo } \\
\text { Followed } \\
30 \text { days later } \\
\text { by other } \\
\text { product in } \\
\text { alternate arm } \\
\text { Route: IM } \\
\text { Follow-up: } \\
5 \text { years - } \\
\text { yearly blood } \\
\text { samples } \\
\text { thereafter }\end{array}$ & $\begin{array}{l}\text { Randomized } \\
\text { controlled trial } \\
\text { Exclusion: prior } \\
\text { IPD, splenectomy, } \\
\text { immune } \\
\text { suppression } \\
\text { Stratified by age } \\
\text { group and prior } \\
\text { history of } \\
\text { pneumococcal } \\
\text { vaccination (at least } \\
3 \text { years before for } \\
\text { those aged } 50-64 \\
\text { and } 3 \text { to } 5 \text { years } \\
\text { before for those } \\
\text { aged } 65 \text { years and } \\
\text { older) }\end{array}$ & $\begin{array}{l}\text { 50-65 yrs, } \\
\text { primary } \\
\text { vaccination = 222 } \\
\text { 50-65 yrs, } \\
\text { revaccination= } 157 \\
\geq 65 \text {, primary } \\
\text { vaccination = } 222 \\
\geq 65 \text { revaccination = } \\
407 \\
\text { Total } n=1008 ; \\
721 \text { participated } \\
\text { in persistence up } \\
\text { to } 5 \text { years } \\
\text { (average } 3.9 \text { years) } \\
\text { Baseline } \\
\text { characteristics } \\
\text { similar between } \\
\text { four groups } \\
\text { except } \\
\text { revaccination } \\
\text { subjects within } \\
\text { each age group } \\
\text { were more likely } \\
\text { to report risk } \\
\text { factors IPD. } \\
\text { Baseline lgG } \\
\text { levels similar } \\
\text { between younger } \\
\text { and older adults } \\
\text { who had not } \\
\text { previously } \\
\text { received } \\
\text { PNEU-P=23 and } \\
\text { between younger } \\
\text { and older adults } \\
\text { who had been } \\
\text { previously } \\
\text { vaccinated. } \\
\text { Baseline lgG levels } \\
\text { were } 2-3 \text { fold } \\
\text { vacciner in those } \\
\text { not vaccinated. }\end{array}$ & 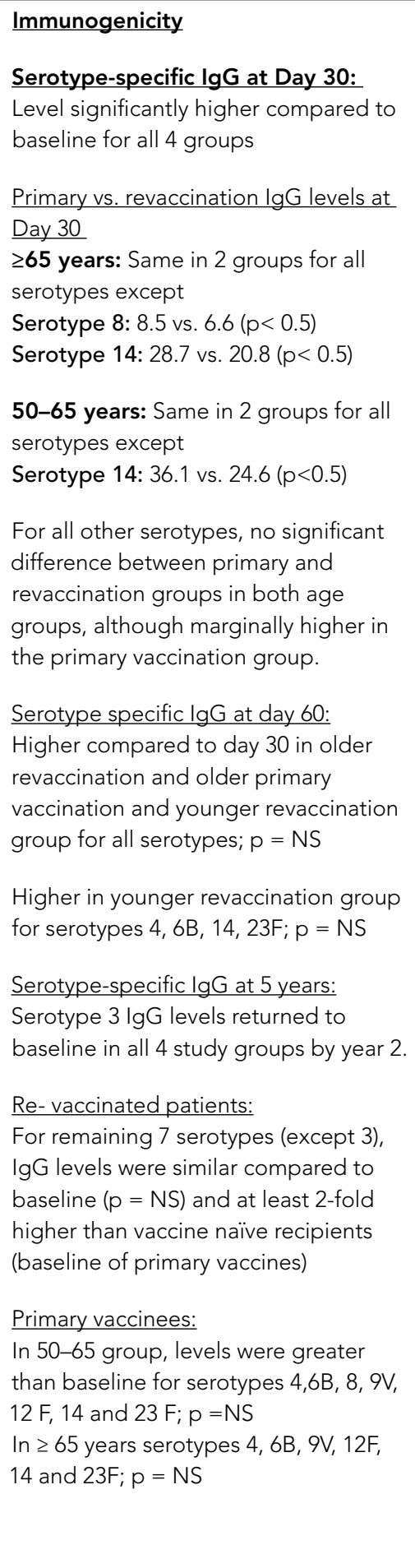 & Level I & Good \\
\hline
\end{tabular}




\begin{tabular}{|c|c|c|c|c|c|c|}
\hline \multicolumn{7}{|c|}{ Evidence for Safety } \\
\hline \multicolumn{5}{|c|}{ STUDY DETAILS } & \multicolumn{2}{|c|}{ SUMMARY } \\
\hline Study & Vaccine & Study Design & Participants & $\begin{array}{l}\text { Summary of Key Findings Using } \\
\text { Text or Data }\end{array}$ & $\begin{array}{l}\text { Level of } \\
\text { Evidence }\end{array}$ & Quality \\
\hline $\begin{array}{l}\text { Frenck, } 2012 \\
\text { (30) }\end{array}$ & $\begin{array}{l}\text { PNEU-C-13/ } \\
\text { TIV - placebo } \\
\text { (1 month later) } \\
\text { vs. } \\
\text { Placebo/ TIV - } \\
\text { PNEU-C-13 } 1 \\
\text { month later } \\
0.5 \mathrm{~mL} \mathrm{IM}\end{array}$ & $\begin{array}{l}\text { Randomized } \\
\text { controlled trial } \\
\text { Population: Healthy } \\
50-59 \text { years of age. } \\
\text { No previous } \\
\text { pneumococcal } \\
\text { vaccination }\end{array}$ & $\begin{array}{l}\text { Multicentric- } \\
\text { U.S. } \\
\mathrm{N}=1158 \text { enrolled } \\
\mathrm{N}=1116 \\
\text { randomized } \\
\mathrm{N} 1=554 \\
\text { (PNEU-C-13/TIV) } \\
\mathrm{N} 2=562 \text { (TIV } \\
\text { then PNEU-C-13) }\end{array}$ & $\begin{array}{l}\text { Safety: } \\
\text { a) Local reactions: proportion } \\
\text { significantly greater in } \\
\text { concomitant vs. TIV alone but } \\
\text { no difference vs. PNEU-C-13 } \\
\text { alone } \\
\text { b) Systemic reactions: increased } \\
\text { proportion of participants with } \\
\text { any systemic event, headache, } \\
\text { chills, rash, decreased appetite, } \\
\text { vomiting, joint and muscle pain } \\
\text { vs. TIV alone but when compared } \\
\text { to PNEU-C-13 alone: only } \\
\text { higher proportion of any } \\
\text { systemic AE and headache }\end{array}$ & Level I & Good \\
\hline $\begin{array}{l}\text { Schwarz, } 2011 \\
\text { (31) }\end{array}$ & $\begin{array}{l}\text { PNEU-C-13/ } \\
\text { TIV - placebo } \\
\text { (1 month later) } \\
\text { vs. } \\
\text { Placebo/ TIV- } \\
\text { PNEU-C-13 } \\
1 \text { month later } \\
0.5 \mathrm{~mL} \mathrm{IM}\end{array}$ & $\begin{array}{l}\text { Randomized } \\
\text { controlled trial } \\
\text { All PNEU-C-13 } \\
\text { serotypes tested } \\
\text { Healthy } 65 \text { years } \\
\text { and over. No } \\
\text { previous } \\
\text { pneumococcal } \\
\text { vaccination } \\
\text { Follow-up until } \\
1 \text { month after last } \\
\text { vaccine } \\
\text { administered }\end{array}$ & $\begin{array}{l}\text { Multicentric - } \\
\text { Europe } \\
\mathrm{N}=1190 \\
\text { participants } \\
\text { enrolled; } 1160 \\
\text { randomized - } \\
580 \text { in each } \\
\text { group } \\
1096 \text { evaluable }\end{array}$ & $\begin{array}{l}\text { Safety: } \\
\text { a) Local reactions: similar in both } \\
\text { groups } \\
\text { b) Systemic reactions: increased } \\
\text { proportion of participants with } \\
\text { chills, rash, muscle pain, any } \\
\text { systemic event in the } \\
\text { concomitant administration } \\
\text { group compared to TIV alone } \\
\text { c) Increased proportion of } \\
\text { participants with fatigue, } \\
\text { headache, chills, decreased } \\
\text { appetite, joint pain, any } \\
\text { systemic even in the } \\
\text { concomitant administration } \\
\text { compared to PNEU-C013 alone }\end{array}$ & Level I & Good \\
\hline
\end{tabular}




\section{TABLE 6. Levels of Evidence Based on Research Design}

\begin{tabular}{l|l}
\hline I & Evidence from randomized controlled trial(s). \\
\hline II-1 & Evidence from controlled trial(s) without randomization. \\
\hline II-2 & $\begin{array}{l}\text { Evidence from cohort or case-control analytic studies, preferably from more than one centre or research group using clinical } \\
\text { outcome measures of vaccine efficacy. }\end{array}$ \\
\hline II-3 & $\begin{array}{l}\text { Evidence obtained from multiple time series with or without the intervention. Dramatic results in uncontrolled experiments } \\
\text { (such as the results of the introduction of penicillin treatment in the 1940s) could also be regarded as this type of evidence. }\end{array}$ \\
\hline III & $\begin{array}{l}\text { Opinions of respected authorities, based on clinical experience, descriptive studies and case reports, or reports of } \\
\text { expert committees. }\end{array}$ \\
\hline
\end{tabular}

\section{TABLE 7. Quality (internal validity) Rating of Evidence}

\begin{tabular}{l|l}
\hline Good & A study (including meta-analyses or systematic reviews) that meets all design- specific criteria* well. \\
\hline Fair & $\begin{array}{l}\text { A study (including meta-analyses or systematic reviews) that does not meet (or it is not clear that it meets) at least one } \\
\text { design-specific criterion* but has no known "fatal flaw". }\end{array}$ \\
\hline Poor & $\begin{array}{l}\text { A study (including meta-analyses or systematic reviews) that has at least one design-specific* "fatal flaw", or an accumulation } \\
\text { of lesser flaws to the extent that the results of the study are not deemed able to inform recommendations. }\end{array}$ \\
\hline
\end{tabular}

* General design specific criteria are outlined in Harris et al., $2001^{1}$.

\section{TABLE 8. NACI Recommendation for Immunization - Grades}

\begin{tabular}{|c|c|}
\hline A & $\mathrm{NACl}$ concludes that there is good evidence to recommend immunization. \\
\hline B & $\mathrm{NACl}$ concludes that there is fair evidence to recommend immunization. \\
\hline C & $\begin{array}{l}\mathrm{NACl} \text { concludes that the existing evidence is conflicting and does not allow making a recommendation for or against } \\
\text { immunization, however other factors may influence decision-making. }\end{array}$ \\
\hline D & $\mathrm{NACl}$ concludes that there is fair evidence to recommend against immunization. \\
\hline E & $\mathrm{NACl}$ concludes that there is good evidence to recommend against immunization. \\
\hline I & $\begin{array}{l}\mathrm{NACl} \text { concludes that there is insufficient evidence (in either quantity and/or quality) to make a recommendation, } \\
\text { however other factors may influence decision-making. }\end{array}$ \\
\hline
\end{tabular}

1 Harris RP, Helfand M, Woolf SH, et al. Current methods of the US Preventive Services Task Force: a review of the process. Am J Prev Med 2001;20:21-35. 


\section{List of Abbreviations}

\begin{tabular}{ll} 
ABBREVIATION & TERM \\
ARV & Anti-retroviral \\
CAP & Community Acquired Pneumonia \\
CNDSS & Canadian Notifiable Disease Surveillance System \\
GMC & Geometric mean concentration \\
GMT & Geometric mean titer \\
HAART & Highly active antiretroviral therapy \\
HSCT & Hematopoietic stem cell transplant \\
IM & Intramuscular \\
IPD & Invasive pneumococcal disease \\
LSPO & Laboratoire de santé publique du Québec \\
MMF & Mycophenolate mofetil \\
NML & National Microbiology Laboratory \\
OPA & Opsophanocytic activity \\
PNEU-C-13 & Trivalent influenza vaccine \\
PNEU-P-23 & Vaccine effectiveness \\
RCT & Pneumococcal conjugate vaccine - 13-valent \\
SOT & Randomized controlled trial \\
TIBDN & Solid organ transplant \\
TIV & Toronto Invasive Bacterial Disease Network \\
VE & Pneccal polysaccharide vaccine - 23-valent \\
\hline
\end{tabular}




\section{References}

(1) An Advisory Committee Statement (ACS). National Advisory Committee on Immunization (NACl). Statement on recommended use of pneumococcal conjugate vaccine. Can Commun Dis Rep. Jan 15 2002;28(ACS-2):1-32.

(2) Update on the recommendations for the routine use of pneumococcal conjugate vaccine for infants. An Advisory Committee Statement (ACS). Can Commun Dis Rep. May 1 2006;32(ACS-4):1-6.

(3) National Advisory Committee on Immunization (NACl). Update on the Use of Pneumococcal Vaccines in Childhood. Can Commun Dis Rep. 2010;36(ACS-12):1-21.

(4) Evidence-based recommendations for immunization-methods of the National Advisory Committee on Immunization. An Advisory Committee Statement (ACS). Can Commun Dis Rep. Jan 2009;35(ACS-1):1-10.

(5) World Health Organization. Pneumococcal Disease. 2012; www.who.int/ith/diseases/pneumococcal/en/ index.html.

(6) Demczuk WH, Martin I, Griffith A, et al. Serotype distribution of invasive Streptococcus pneumoniae in Canada during the introduction of the 13-valent pneumococcal conjugate vaccine, 2010. Can J Microbiol. Aug 2012;58(8):1008-1017.

(7) National Microbiology Laboratory. National Laboratory Surveillance of Streptococcus pneumoniae and Streptococcus pyogenes in Canada: Annual Summary 20102010.

(8) National Microbiology Laboratory. National Laboratory Surveillance of Streptococcus pneumoniae and Streptococcus pyogenes in Canada: Annual Summary 20112011.

(9) French N, Gordon SB, Mwalukomo T, et al. A trial of a 7-valent pneumococcal conjugate vaccine in HIV-infected adults. N Engl J Med. Mar 4 2010;362(9):812-822.

(10) Siemieniuk RA, Gregson DB, Gill MJ. The persisting burden of invasive pneumococcal disease in HIV patients: an observational cohort study. BMC Infect Dis. 2011;11:314.
(11) Breiman RF, Keller DW, Phelan MA, et al. Evaluation of effectiveness of the 23-valent pneumococcal capsular polysaccharide vaccine for HIV-infected patients. Arch Intern Med. Sep 25 2000;160(17):2633-2638.

(12) Hung CC, Chen MY, Hsieh SM, Hsiao CF, Sheng WH, Chang SC. Clinical experience of the 23-valent capsular polysaccharide pneumococcal vaccination in HIV-1-infected patients receiving highly active antiretroviral therapy: a prospective observational study. Vaccine. May 7 2004;22(15-16):2006-2012.

(13) French N, Nakiyingi J, Carpenter LM, et al. 23-valent pneumococcal polysaccharide vaccine in HIV-1-infected Ugandan adults: double-blind, randomised and placebo controlled trial. Lancet. Jun 17 2000;355(9221):2106-2111.

(14) Vila-Corcoles A, Ochoa-Gondar O, Llor C, Hospital I, Rodriguez T, Gomez A. Protective effect of pneumococcal vaccine against death by pneumonia in elderly subjects. Eur Respir J. Dec 2005;26(6):1086-1091.

(15) Vila-Corcoles A, Ochoa-Gondar O, Hospital I, et al. Protective effects of the 23-valent pneumococcal polysaccharide vaccine in the elderly population: the EVAN-65 study. Clin Infect Dis. Oct 1 2006;43(7):860-868.

(16) Mooney JD, Weir A, McMenamin J, et al. The impact and effectiveness of pneumococcal vaccination in Scotland for those aged 65 and over during winter 2003/2004. BMC Infect Dis. 2008;8:53.

(17) Melegaro A, Edmunds WJ. The 23-valent pneumococcal polysaccharide vaccine. Part I. Efficacy of PPV in the elderly: a comparison of meta-analyses. Eur J Epidemiol. 2004;19(4):353-363.

(18) Nahm MH, Romero-Steiner S. Functional Assays for Pneumococcal Antibody. In: Siber G, Klugman KP, Makela PH, eds. Pneumococcal Vaccines - The Impact of Conjugate Vacine. Washington, DC: ASM Press; 2008:449.

(19) Kumar D, Chen MH, Wong G, et al. A randomized, double-blind, placebo-controlled trial to evaluate the prime-boost strategy for pneumococcal vaccination in adult liver transplant recipients. Clin Infect Dis. Oct 1 2008;47(7):885-892. 
(20) Kumar D, Rotstein C, Miyata G, Arlen D, Humar A. Randomized, double-blind, controlled trial of pneumococcal vaccination in renal transplant recipients. J Infect Dis. May 15 2003;187(10):1639-1645.

(21) Kumar D, Welsh B, Siegal D, Chen MH, Humar A. Immunogenicity of pneumococcal vaccine in renal transplant recipients--three year follow-up of a randomized trial. Am J Transplant. Mar 2007;7(3):633-638.

(22) Tobudic S, Plunger V, Sunder-Plassmann G, Riegersperger M, Burgmann $\mathrm{H}$. Randomized, single blind, controlled trial to evaluate the prime-boost strategy for pneumococcal vaccination in renal transplant recipients. PLoS One. 2012;7(9):e46133.

(23) Cordonnier C, Labopin M, Chesnel V, et al. Randomized study of early versus late immunization with pneumococcal conjugate vaccine after allogeneic stem cell transplantation. Clin Infect Dis. May 15 2009; 48(10):1392-1401.

(24) Molrine DC, Antin JH, Guinan EC, et al. Donor immunization with pneumococcal conjugate vaccine and early protective antibody responses following allogeneic hematopoietic cell transplantation. Blood. Feb 1 2003;101(3):831-836.

(25) Kumar D, Chen MH, Welsh B, et al. A randomized, double-blind trial of pneumococcal vaccination in adult allogeneic stem cell transplant donors and recipients. Clin Infect Dis. Dec 15 2007;45(12):1576-1582.

(26) Feikin DR, Elie CM, Goetz MB, et al. Randomized trial of the quantitative and functional antibody responses to a 7-valent pneumococcal conjugate vaccine and/or 23-valent polysaccharide vaccine among HIV-infected adults. Vaccine. Nov 12 2001;20(3-4):545-553.

(27) Penaranda M, Payeras A, Cambra A, Mila J, Riera M. Conjugate and polysaccharide pneumococcal vaccines do not improve initial response of the polysaccharide vaccine in HIV-infected adults. Aids. May 15 2010;24(8):1226-1228.

(28) Crum-Cianflone NF, Huppler Hullsiek K, Roediger M, et al. A randomized clinical trial comparing revaccination with pneumococcal conjugate vaccine to polysaccharide vaccine among HIV-infected adults. J Infect Dis. Oct 12010 ; 202(7):1114-1125.

(29) Lesprit P, Pedrono G, Molina JM, et al. Immunological efficacy of a prime-boost pneumococcal vaccination in HIV-infected adults. Aids. Nov 30 2007;21(18):2425-2434.
(30) Frenck RW, Jr., Gurtman A, Rubino J, et al. Randomized, controlled trial of a 13-valent pneumococcal conjugate vaccine administered concomitantly with an influenza vaccine in healthy adults. Clin Vaccine Immunol. Aug 2012;19(8):1296-1303.

(31) Schwarz TF, Flamaing J, Rumke HC, et al. A randomized, double-blind trial to evaluate immunogenicity and safety of 13-valent pneumococcal conjugate vaccine given concomitantly with trivalent influenza vaccine in adults aged $>/=65$ years. Vaccine. Jul 18 2011; 29(32):5195-5202.

(32) Jackson LA, Neuzil KM, Nahm MH, et al. Immunogenicity of varying dosages of 7-valent pneumococcal polysaccharide-protein conjugate vaccine in seniors previously vaccinated with 23 -valent pneumococcal polysaccharide vaccine. Vaccine. May 16 2007;25(20):4029-4037.

(33) de Roux A, Schmole-Thoma B, Siber GR, et al. Comparison of pneumococcal conjugate polysaccharide and free polysaccharide vaccines in elderly adults: conjugate vaccine elicits improved antibacterial immune responses and immunological memory. Clin Infect Dis. Apr 1 2008;46(7):1015-1023.

(34) Miernyk KM, Butler JC, Bulkow LR, et al. Immunogenicity and reactogenicity of pneumococcal polysaccharide and conjugate vaccines in alaska native adults $55-70$ years of age. Clin Infect Dis. Jul 15 2009;49(2):241-248.

(35) Goldblatt D, Southern J, Andrews N, et al. The immunogenicity of 7-valent pneumococcal conjugate vaccine versus 23 -valent polysaccharide vaccine in adults aged 50-80 years. Clin Infect Dis. Nov 12009 ; 49(9):1318-1325.

(36) Schenkein JG, Park S, Nahm MH. Pneumococcal vaccination in older adults induces antibodies with low opsonic capacity and reduced antibody potency. Vaccine. Oct 9 2008;26(43):5521-5526.

(37) Musher DM, Manoff SB, Liss C, McFetridge RD, Marchese RD, Bushneil B, Alvarez F, Painter C, Blum $M D$, Silber JL. Safety and antibody response, including antibody persistence for 5 years, after primary vaccination or revaccination with pneumococcal Polysaccharide vaccine in middle-aged and older adults. $J$ Infect Dis. Oct 1 2010;201(4):516-524. 
(38) Pfizer Canada. Product Monograph - Prevnar 13. 2012; www.pfizer.ca/en/our_products/products/monograph/232. Accessed 2012-08-28.

(39) Vanderkooi OG, Scheifele DW, Girgenti D, et al. Safety and immunogenicity of a 13-valent pneumococcal conjugate vaccine in healthy infants and toddlers given with routine pediatric vaccinations in Canada.

Pediatr Infect Dis J. Jan 2012;31(1):72-77. 